\title{
Capítulo 4 - A Real Biblioteca e a grandeza da monarquia luso-brasileira
}

\author{
Juliana Gesuelli Meirelles
}

\section{SciELO Books / SciELO Livros / SciELO Libros}

MEIRELLES, J. G. A Real Biblioteca e a grandeza da monarquia luso-brasileira. In: Política e cultura no governo de Dom João VI: imprensa, teatros, academias e bibliotecas (1792-1821) [online]. São Bernardo do Campo, SP: Editora UFABC, 2017, pp. 331-430. ISBN 978-85-68576-87-8. https://doi.org/10.7476/9788568576878.0005.

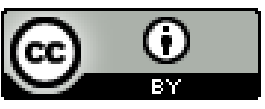

All the contents of this work, except where otherwise noted, is licensed under a Creative Commons Attribution 4.0 International license.

Todo o conteúdo deste trabalho, exceto quando houver ressalva, é publicado sob a licença Creative Commons Atribição 4.0.

Todo el contenido de esta obra, excepto donde se indique lo contrario, está bajo licencia de la licencia Creative Commons Reconocimento 4.0. 


\section{A REAL BIBLIOTECA E A GRANDEZA DA MONARQUIA LUSO-BRASILEIRA}

\subsection{Preâmbulo}

[Não há] nenhum meio mais honesto e seguro para adquirir uma grande fama entre os povos, que construir belas e magníficas bibliotecas, para depois voltá-las e consagrá-las ao público. Por isso, é verdade que esse empreendimento nunca enganou nem decepcionou os que o souberam conduzi-lo bem; ele sempre foi julgado de tais consequências, que não somente os particulares

o fizeram resultar em sua vantagem [...], que mesmo os mais ambiciosos sempre quiseram se servir dele para coroar e aperfeiçoar todas as suas belas ações, como se faz com a pedra angular, que fecha a abóbada e serve de brilho e ornamento a todo o resto do edifício.

Gabriel Naudé, $1627 .{ }^{1}$

1 NAUDÉ, Gabriel. Advis pour dresser une bibliothèque (Conselhos para organizar uma biblioteca) Apud CHARTIER, Roger. "O príncipe, a biblioteca e a dedicatória”. In: BARATIN, Marc; JACOB, Christian. O poder das bibliotecas: a memória dos livros no ocidente. Trad. Marcela Mortara. 2. ed. Rio de Janeiro: Editora UFRJ, 2006. p. 184. 
A arguta observação do bibliotecário francês em meados do século XVII nos aponta para uma importante estratégia política das monarquias absolutistas na Idade Moderna: a consolidação do poder real perpassava necessariamente pela construção simbólica da sua autoridade. Como já bem analisou Peter Burke, Luís XIV (1643-1715) contou com o auxílio de homens do governo para a construção de sua imagem durante todo o seu reinado, o que implicava marcar sua figura entre os súditos como o rei acessível, protetor das artes e das letras. Enfim, ao idealizá-lo como o mais poderoso monarca do universo, seus homens de Estado tiveram a árdua tarefa de estruturar uma ampla propaganda das qualidades do Rei Sol em múltiplos sentidos. ${ }^{2}$ Do cunho das medalhas às Academias. Das cerimônias públicas às peças de teatro. Do patrocínio de artistas às coleções de livros.

Se a promoção do Estado francês foi presente nos diversos locus de cultura com vistas a manter um diálogo cultural eficiente, nos interessa aqui ressaltar a importância e o sentido da biblioteca real no governo de Luís XIV. Como definiu o historiador Roger Chartier, a biblioteca

[...] não é um solitarium, um lugar de retiro fora do mundo, e de gozos secretos. Abertas aos literatos, aos eruditos, mesmo aos simples curiosos (é o caso na biblioteca do rei a partir de 1692), suas coleções de manuscritos e impressos podem ser mobilizadas a serviço do saber, da história da monarquia, da política ou da propaganda do Estado. ${ }^{3}$

Ao enfocar os diversos usos da biblioteca do rei, concebida no Ocidente como o lugar de memória ${ }^{4}$, Chartier também coloca

\footnotetext{
2 BURKE, Peter. A fabricação do rei. A construção da imagem pública de Luis XIV. Rio de Janeiro: Jorge Zahar, 1994.

${ }^{3}$ CHARTIER, Roger. "O príncipe, a biblioteca e a dedicatória”. In: BARATIN, Marc; JACOB, Christian. O poder das bibliotecas:... Op. Cit., p. 185.

${ }^{4}$ De acordo com o historiador Christian Jacob, "[...] a história das bibliotecas no Ocidente é indissociável da história da cultura e do pensamento, não só
} 
em cena uma questão de suma relevância: a composição das coleções reais evidencia vários gestos historicamente circunscritos advindos de múltiplos sujeitos. Isto é, do confisco de obras após expedições militares vitoriosas à doação de livros pela própria realeza, perpassando a aquisição (e concessão) de obras particulares adquiridas no exterior por súditos, viajantes, ministros reais ou correspondentes, notamos que, a despeito do caminho trilhado nesse processo, há, sim, um explícito interesse coletivo com fortes vieses sociopolíticos - na manutenção desse locus de cultura como espaço de destaque. "A constituição das coleções da biblioteca é fruto de uma política sistemática de aquisições, que busca a completude, a acumulação de todas as formas de saber e de criação confiadas à escrita, aptas a serem em seguida redistribuídas pela classificação nas grandes categorias", afirma o historiador Christian Jacob. ${ }^{5}$

Desde Alexandria, a força simbólica de inúmeros livros concentrados em um mesmo lugar, cujo conhecimento se põe ao alcance do público tornou-se, sem dúvida, uma manifestação de superioridade intelectual e poder político; razão pela qual, segundo Gabriel Naudé, "um número quase infinito de muitos monarcas" acumulou milhares de obras e mandou construir "bibliotecas muito curiosas e bem providas". ${ }^{6}$ É por esse prisma, portanto, que compreendemos o sentido da acumulação do conhecimento nos

como lugar de memória, no qual se depositam os estratos das inscrições deixadas pelas gerações passadas, mas também como espaço dialético no qual, a cada etapa da história, se negociam os limites e as funções da tradição, as fronteiras do dizível, do legível, e do pensável, a continuidade das genealogias e das escolas, a natureza cumulativa dos campos do saber ou suas fraturas internas e suas reconstruções." JACOB, Christian. "Prefácio". In: BARATIN, Marc; JACOB, Christian. O poder das bibliotecas:... Op. Cit., p. 11.

${ }^{5}$ Ibid., p. 51.

${ }^{6}$ NAUDÉ, Gabriel. Advis pour dresser une bibliothèque... Op. Cit., p. 184. 
diversos campos do saber - as belas letras, teologia, ciências e arte, história e jurisprudência ${ }^{7}$ - como uma base imprescindível de sustentação política das monarquias europeias na Idade Moderna.

O reinado de D. João V (1706-1750) foi contemporâneo ao de Luís XIV. Vividos no auge do Antigo Regime, ambos os governos foram marcados pela magnanimidade. Enquanto na França resplandecia pela Europa a suntuosidade e força de Versailles, em Portugal D. João V dedicava-se a uma de suas célebres realizações, a construção do Palácio de Mafra. Para além do Convento, a constituição das bibliotecas do Reino - com destaque para a biblioteca real - foi concebida como mola-mestra de sua política cultural. Segundo pesquisadores portugueses, toda a preocupação joanina com as bibliotecas como locus de saber de alta consideração, fez parte de um "programa criteriosamente delineado que procurava inspiração e modelo no que de melhor se fazia na Europa". ${ }^{8}$ Delineava-se, assim, a profícua comunicação entre a coroa lusitana e seus súditos enviados para as cortes mais polidas do Velho Mundo, como Inglaterra, França e Países Baixos. Em 1721, o súdito português Antonio Galvão de Castelo Branco fazia um extenso relatório acerca das bibliotecas inglesas, onde garantia a patente diferença com os conventos lusitanos. ${ }^{9}$

Os constantes pedidos de $\mathrm{D}$. João $\mathrm{V}$ pouco a pouco enriqueciam o locus, que chegou a ter 70 mil volumes. ${ }^{10}$ De listas de

\footnotetext{
${ }^{7}$ Aqui utilizamos a classificação herdada da Encyclopédie vigente no século XVIII que adentrou o início do século XIX, uma vez que é justamente esse o nosso recorte temporal da pesquisa (1792-1821).

8 CLUNY, Isabel; BARATA, Paulo. J. S. "A propósito de um documento da política cultural joanina”. In: Leituras. Revista da Biblioteca Nacional. S.3. n ${ }^{\circ} 3$. Lisboa: 1998. p. 132.

${ }^{9}$ FERRAUD, Luís Almeida. “D. João V e a biblioteca real”. Revista da Universidade de Coimbra. N. ${ }^{\circ}$ XXXVI, 1991. p. 431.

${ }_{10}$ Verbete: Livraria Real. In: <http://www.infopedia.pt/\$livraria-real>. (Data do acesso: 06/07/2012).
} 
manuscritos e livros avulsos à compra de livrarias inteiras, o amplo mosaico de temas e coleções ganhava grande visibilidade. ${ }^{11}$ Ao fim da década de 1720, a biblioteca lisboeta já era considerada uma das maiores e mais preciosas da Europa, despertando o interesse, inclusive, de livreiros internacionais que passaram a frequentar a corte lusitana. ${ }^{12}$ A grandiosidade desse espaço, por si só, já justificava o fato de o monarca ter sido batizado como o Rei Sol português.

A despeito do sucesso da política cultural joanina, o terremoto de 1755 destruiu boa parte de Lisboa, não poupando um dos maiores empreendimentos governamentais: a livraria real, situada no Paço da Ribeira. Sua reconstrução durante a segunda metade do século XVIII, assim como a transladação de parte importante de seu acervo para o Brasil, no início d'Oitocentos, é um tema que tem despertado grande interesse da historiografia luso-brasileira nas últimas décadas. ${ }^{13}$

\footnotetext{
${ }^{11}$ FERRAUD, Luís Almeida. “D. João V e a biblioteca real”... Op. Cit., p. 421.

12 "Um dos mercadores de livros mais importantes da época, o francês Pedro Gendron, homem erudito em conhecimentos bibliográficos e que conhecia muitas bibliotecas da Europa, afirmava que nenhuma vira provida de tantas edições antigas como a Real." DOMINGOS, Manoela. "A primeira biblioteca pública portuguesa, 1775-1795. Planos, projetos e primeiros fundos". Cadernos BAD (1) 1994. p. 59.

13 Entre muitos estudos, destacamos: DOMINGOS, Manuela. "Historial da Biblioteca Nacional”. In: DOMINGOS, Manuel; LOPES, Inês; OLIVEIRA, Antonio Lopes de. Biblioteca Nacional de Portugal. Lisboa: ABINIA, 1994; SCHWARCZ, Lilia M., AZEVEDO, Paulo César de; COSTA, Ângela Márquez da, A longa viagem da biblioteca dos reis: do terremoto de Lisboa à Independência do Brasil, São Paulo: Cia das Letras, 2002; NEVES, Lúcia Maria Bastos Pereira das. "O livro para se fazer memória de todas as obras que entrarem na Real Biblioteca” In: ALGRANTI, Leila Mezan; MEGIANI, Ana Paula. (Org.). O Império por escrito: formas de transmissão da cultura letrada no mundo ibérico. Séc. XVI-XIX. São Paulo: Ed. Alameda, 2009. p. 277-296; SILVA, Maria Beatriz Nizza. A cultura luso-brasileira:... Op. Cit.
} 
Neste capítulo, o nosso foco está na compreensão da política cultural durante a governança de D. João (1792-1821) tendo a biblioteca real como um dos pilares de sustentação da monarquia portuguesa no auge da crise do Antigo Regime. Transladar um enorme acervo para o Rio de Janeiro, em três viagens distintas ${ }^{14}$, esteve longe de ser um empreendimento tranquilo. Apesar disso, se mostrou fundamental no processo de metropolização da nova corte. "Mais do que um edifício com prateleiras, uma biblioteca representa uma coleção e seu projeto. Afinal, qualquer acervo não só traz embutida uma concepção implícita de cultura e saber, como desempenha diferentes funções, dependendo da sociedade em que se insere", conceitua a antropóloga Lilia Schwarcz. ${ }^{15}$

Em março de 1811, adentrava no Brasil a segunda remessa de livros vindos de Lisboa sob a responsabilidade de Luís Joaquim dos Santos Marrocos, funcionário régio que cuidou da travessia do precioso acervo bibliográfico da realeza. Marrocos viveu deste lado do Atlântico até o fim da vida e durante o período que nos interessa exerceu um cargo de destaque na sociedade de corte: foi bibliotecário régio, além de ser um astuto observador da nova realidade carioca.

Três anos depois de sua chegada, em 1814, a real biblioteca abria suas portas ao público. Mesmo sem ter acesso ao espaço nos três anos precedentes, a sociedade joanina já contava com os livros produzidos pela Impressão Régia desde 1808. A despeito da atuante censura joanina, a produção, circulação e leitura de livros, almanaques e diversos periódicos como a Gazeta do Rio de Janeiro, O Patriota e O Investigador Portuguez se tornava

14 SCHWARCZ, Lilia M., AZEVEDO, Paulo César de; COSTA, Ângela Márquez da. A longa viagem da biblioteca... Op. Cit., p. 268-269.

15 Ibid., p. 120. 
uma realidade no Rio de Janeiro no alvorecer do século XIX. Tais medidas governamentais impulsionaram transformações sociopolíticas e culturais importantes ao longo dos treze anos de vigência da corte no Brasil, mudando em definitivo a face da América Portuguesa.

Enfim, surgia a possibilidade de se fazer novas leituras críticas acerca de um mundo em crise ideológica e em rápida mutação, que via novos sujeitos emergirem no espaço urbano da corte. O papel desses múltiplos sujeitos e a força transformadora dos livros no período joanino é o assunto central deste capítulo. Como magistralmente nos esclarece o historiador Robert Darnton, os livros não respeitam fronteiras linguísticas ou nacionais, não se limitando, portanto, a relatar a história. Eles a fazem. ${ }^{16}$

\subsection{Soberania política e a constituição da Real Biblioteca Pública da Corte}

A política não é sempre a causa das revoluções de Estado. Fenômenos espantosos mudam frequentemente a face dos Impérios. Pode dizerse que esses desastres da natureza são algumas vezes necessários porque eles podem mais do que qualquer outra coisa contribuir e aniquilar certos sistemas que se encaminham a invadir o universal Império [...] Porém dirão é necessário que sobre a terra se transportem províncias, que se subvertam cidades para dissipar a cegueira de certas nações, ilustrá-la no conhecimento dos seus

16 DARNTON. Robert. O Beijo de Lamourette: mídia, Cultura e Revolução, São Paulo: Cia das Letras, 1995. p. 130. 
verdadeiros interesses. Sim, atrevidamente o digo, em um certo sentido assim é necessário.

Sebastião de Carvalho e Melo, 1755.

A reflexão acima faz parte do Discurso político sobre as vantagens que o reino de Portugal pode alcançar da sua desgraça por ocasião do memorável Terremoto de $1^{\circ}$ de novembro de 1755 , feito pelo então futuro primeiro-ministro de D. José I em meio aos escombros de Lisboa. Como sabemos, as consequências do terremoto foram desastrosas: com milhares de mortos e a miséria que se abateu sobre a sociedade portuguesa, a reconstrução da cidade se fazia urgente. Coincidentemente, a reedificação da corte - ocorrida sob o paradigma do Iluminismo, em que vigorava a concepção de cidade ilustrada ${ }^{17}$ - teve na figura do futuro Marquês de Pombal o seu principal expoente. Ministro ilustrado de D. José I, Pombal utilizou-se do terremoto para ganhar visibilidade na política europeia.

O Estado português tomou medidas emergenciais para tirar a capital do Reino do caos: do alojamento dos sobreviventes ao enterro em massa dos mortos, o cuidado com a salubridade foi de primeira ordem. Ademais, o socorro a Portugal veio de todas as partes: do Brasil à Inglaterra, as cortes estrangeiras estiveram atentas e dispostas a ajudar materialmente o país. Apesar disso, nos interessa enfatizar a administração pombalina sobretudo no que se refere à reconstrução da biblioteca real que, como já dissemos, foi um dos mais destacados locus de cultura de sustentação política das monarquias absolutistas. Neste particular, como

17 CARVAlHO, Marieta Pinheiro de. Uma idéia de cidade ilustrada: as transformações urbanas no Rio de Janeiro de D. João VI (1808-1821). Rio de Janeiro: Odisséia, 2008. p. 28. 
apontou a análise da historiadora portuguesa Manuela Domingos, na reconstrução de Lisboa, agora pelo prisma das Luzes, foi intrínseca a elevação de novos edifícios e novas instituições, sobremaneira as de explícito caráter cultural, ou seja, as bibliotecas, universidade e centros de ensino. ${ }^{18}$

Por essa ótica, já em 1756, o governo josefino buscava viabilizar uma nova coleção. Uma das soluções encontradas por Pombal a fim de evitar outra perda significativa dos livros foi a transferência da Real Livraria para o Palácio da Ajuda, onde a realeza passava a residir. Além disso, a tragédia também impulsionou a idealização de dois grandes acervos. "Ao mesmo tempo em que se organizava a Real Biblioteca junto ao novo paço da Ajuda, erguia-se de forma autônoma, a Real Biblioteca pública", contextualiza a autora Lilia Schwarcz, que também realça o fato de esta ter sido criada "no âmbito da Real Mesa Censória e dimensionada na medida das grandes bibliotecas europeias". ${ }^{19}$ A primeira Biblioteca Pública da Corte (1775-1795) foi um projeto pombalino cujo destaque devia ser a desvinculação com o ensino jesuítico. Neste sentido, a "política do livro" no espaço privilegiava o ensino laico. ${ }^{20}$

A nova coleção da Real Biblioteca da Ajuda contou com três aquisições de destaque. A primeira delas foi a livraria privada do Conde de Redondo, negociada pessoalmente por D. José I. Sob a custódia de sua esposa, a Condessa de Redondo, o acervo contava com um respeitável número de obras e também manuscritos de história que primavam pela qualidade da conservação. A nobre proprietária sabia do valor de seu empreendimento, uma

18 DOMINGOS, Manuela. "Historial da Biblioteca Nacional"...Op. Cit., p. 6.

19 SCHWARCZ, Lilia M. A longa... Op. Cit., p. 140.

20 DOMINGOS, Manoela. "A primeira biblioteca pública portuguesa, 1775 1795...,, Op. Cit., p. 60-61. 
vez que pedia ao rei três mil cruzados em dinheiro e seis em padrão de juro para fechar o negócio. ${ }^{21}$ A livraria do gazeteiro José Maria Monterroio de Mascarenhas foi a segunda conquista real. Composta por dicionários e livros genealógicos, a biblioteca de Mascarenhas destacava-se pela natureza de suas obras de origem castelhana, inglesa e portuguesa. ${ }^{22}$ Porém, o investimento de maior vulto intelectual da Coroa foi a aquisição da coleção do abade Diogo Barbosa Machado, negociada por Frei Manoel do Cenáculo Vilas Boas, entre os anos de 1770 e $1773 .{ }^{23}$

De acordo com o pesquisador Rodrigo Bentes Monteiro, a doação da coleção à Real Biblioteca expressa bem o coroamento de uma trajetória. Se durante os anos 1770 a 1772 Barbosa Machado prestou serviço ao rei, cuja atuação destacava-se pelo mecenato e interesse em associar sua imagem régia à preciosa compilação, o agradecimento do monarca também foi à altura, vindo através de mercê em forma de pensão. ${ }^{24} \mathrm{O}$ significado simbólico do desempenho do proeminente bibliófilo está, segundo Monteiro, intrinsecamente associado ao valor da construção póstuma de sua memória. Neste sentido, o fato de sua coleção atravessar o Atlântico, viajando com a corte para o Brasil, o enobrecia historicamente. Isto é, em meio às memórias dos reis, nobres, heróis de batalha, sacerdotes insignes e santos, aparecia a figura de Barbosa

\footnotetext{
21 SCHWARCZ, Lilia M. A longa... Op. Cit., p. 141.

22 Sobre a atuação de Mascarenhas enquanto Gazeteiro ver BELO, André. As Gazetas e os Livros: a Gazeta de Lisboa e a vulgarização do impresso (1715-1760). Lisboa, 2001; MEIRELLES, Juliana Gesuelli. Imprensa e poder... Op. Cit., p. 49-55.

23 Para as biografias de ambos os religiosos e homens de letras - Diogo Barbosa Machado (1682-1772) e Frei Manoel do Cenáculo Vilas Boas (1724-1814), ver http://www.arqnet.pt/dicionario/barbosamachadod.html e http://www.arqnet. $\mathrm{pt} /$ dicionario/vilasbcenaculo.html respectivamente.

24 MONTEIRO, Rodrigo Bentes. "Folhetos em ordem na coleção Barbosa Machado”. In: ALGRANTI, Leila Mezan; MEGIANI, Ana Paula. (Org.). O Império por escrito... Op. Cit., p. 209.
} 
Machado. "Essas histórias conferiam superioridade a este colecionador apaixonado, como ficção de sua soberania viva", conclui Monteiro. ${ }^{25}$

Rodrigo B. Monteiro tem como prisma de análise o trabalho desse súdito português na lógica da conservação e transmissão do conhecimento, própria ao Antigo Regime Português, sobremaneira no que tange à força da censura régia. Das escolhas temáticas aos múltiplos sentidos da classificação de suas obras, o historiador também investiga o impacto da coleção de Barbosa Machado deste lado do Atlântico desde 1810, quando houve a incorporação do acervo à Real Biblioteca do Rio de Janeiro, atual Biblioteca Nacional. ${ }^{26}$ Assim sendo, é imprescindível realçar a centralidade do abade de Santo Adrião de Server como homem de letras, bibliófilo e colecionador da história do Império Português. Biblioteca Lusitana. História, Crítica e Cronologia é de sua autoria e foi considerada por ele próprio a sua obra maior.

Organizada em quatro tomos, Biblioteca Lusitana foi dedicada aos monarcas D. João V e D. José I, tendo como principal finalidade apresentar ao leitor as personagens de renome da história do país. Em forma de biografia, mais de cinco mil figuras são catalogadas em ordem alfabética, com ênfase para os líderes políticos, intelectuais, nobres e religiosos. Na análise de Monteiro, a obra de Machado constitui um "valioso instrumento de

25 Ibid., p. 209.

${ }^{26}$ MONTEIRO, Rodrigo Bentes. "Reis, príncipes e varões insignes na coleção Barbosa Machado”. Anais de História de Além-Mar, Lisboa, v. VI, n. 2005. p. 215-251, 2005. A importância da coleção Barbosa Machado é um tema ainda pouco estudado pela historiografia brasileira. Apesar de exaltarmos a importância do assunto, ressaltamos que o objetivo central desta tese é compreender a biblioteca como um locus de cultura fundamental dentro da política cultural do governo joanino; nesse sentido, o aprofundamento das especificidades de tal discussão acadêmica extrapola os limites desse trabalho. 
consulta para pesquisadores, espécie de dicionário dos conhecimentos em Portugal e de seus grandes vultos". Já pela ótica de Schwarcz, a mesma obra representa um exercício de exaltação do poder real. ${ }^{27}$ Para nosso trabalho, no entanto, nos interessa trazer à luz o empenho da monarquia portuguesa em relação à aquisição da biblioteca de Barbosa Machado, a ponto de o cuidado com o deslocamento dos livros ter sido tratado como questão prioritária do Estado. A empreitada contou com a assídua colaboração do então diretor da Imprensa Régia, o livreiro-impressor italiano Nicolau Pagliarini, que também dirigia as livrarias do Paço das Necessidades e do Colégio dos Nobres. Além disso, Pagliarini era publicamente antijesuíta, o que corroborava com a reforma educacional pombalina. ${ }^{28}$

De viés laicizante e pragmático, a reforma pedagógica atingiu todos os níveis de ensino no país, das primeiras letras à universidade. Se o ápice dessas transformações deu-se com a reforma da Universidade de Coimbra (1772), desde a expulsão dos jesuítas do Império Português, em 1759, o Estado assumiu diretamente a responsabilidade sobre a instrução escolar, cobrando um imposto, o subsídio literário, e introduzindo as aulas régias. ${ }^{29}$ E dentro desse contexto político, a criação da Real Mesa Censória é uma questão singular que esteve indissociável tanto da nova concepção de educação ilustrada dos súditos da monarquia - que ganhava cada vez mais centralidade -, quanto da "política

SCHWARCZ, Lilia M. A longa... Op. Cit., p. 145.

${ }^{28}$ DOMINGOS, Manuela. “A primeira biblioteca pública portuguesa..., Op. Cit., p. 64.

29 VILLALTA, Luiz Carlos. "O que se fala e o que se lê: língua, instrução e leitura”, In: SOUZA, Laura de Melo e (org.). Cotidiano e vida privada na América Portuguesa, História da vida privada no Brasil. São Paulo: Cia das Letras, 1997. p. 348. 
do livro" ${ }^{" 30}$, que o primeiro-ministro tentava imprimir ao Império Português. "Com a criação da Real Mesa Censória, em abril de 1768, Pombal retirou do tribunal do Santo Ofício e do Ordinário a prerrogativa de responsáveis pela censura religiosa e passou-a para a alçada do Estado, secularizando a ação da censura e tornando-a, assim, um instrumento do Estado absolutista", ratifica a historiadora Leila Mezan Algranti. ${ }^{31}$ Ainda sobre essa importante transformação política, a autora realça a responsabilidade do novo órgão estatal no processo de censura e fiscalização de toda a produção impressa que circularia nos dois lados do Atlântico, em que pesava também a posição dos censores régios, homens diretamente subordinados ao rei e, portanto, de sua estrita confiança.

Foi também durante o governo pombalino que se iniciou o projeto da primeira Biblioteca Pública portuguesa (1775-1795). A idealização do novo espaço teve como autor frei Manuel do Cenáculo Villas-Boas, um dos mais eminentes colaboradores do primeiro-ministro no campo do ensino e da cultura. Em relação à composição do acervo, Cenáculo propôs o subsídio literário ${ }^{32}$ que, segundo ele, seria usado para "formar uma das mais importantes Bibliotecas da Europa, também decorada de preciosos Manuscritos e dos livros raros escolhidos" tanto quanto compor um "MUSEU DE RARIDADES de que dão exemplo de estímulo e paixão as Nações cultas que em breve receberiam exemplo

\footnotetext{
${ }^{30}$ Utilizo essa expressão da historiadora portuguesa Manoela Domingos. DOMINGOS, Manoela. "A primeira biblioteca pública portuguesa..., Op. Cit., p. 60-61. 31 ALGRANTI, Leila Mezan. Livros de Devoção..., Op. Cit., p. 135.

32 De acordo com Manuela Domingos, o subsídio literário consistia em um imposto sobre as bebidas alcoólicas cujo fim seria o financiamento de redes de escolas menores em todo o país. Tal subsídio também serviria para pagar os professores régios assim como editar novos manuais pedagógicos. DOMINGOS, Manuela. “A primeira biblioteca pública portuguesa..., Op. Cit., p. 62.
} 
significativo desta capital". ${ }^{33} \mathrm{O}$ discurso do frei nos coloca diante de uma questão muito cara aos homens de letras portugueses da segunda metade do século XVIII: o compasso cultural entre Portugal e a Europa do norte era primordial e deveria ser atingido através do progresso da razão e das artes, sendo os livros um dos principais objetos culturais responsáveis por essa transformação. ${ }^{34}$

Por esse prisma, a reflexão de Roger Chartier acerca da política editorial dos impressores da Biblioteca Azul, na França da idade moderna, é de grande relevância. Apesar de ser de natureza absolutamente diferente de uma biblioteca real, justamente por ter sido ambulante e voltada para um público popular e rural ${ }^{35}$, todos os catálogos da Biblioteca Azul foram escolhidos "porque parecem poder ser comprados por um grande público e, portanto, suscetíveis de responder a uma expectativa partilhada, seja de ordem de devoção, da utilidade ou do imaginário". ${ }^{36}$ É precisamente neste aspecto que devemos nos atentar.

A despeito das peculiaridades de cada sociedade e, mormente da concepção de duas bibliotecas com características tão distintas, não podemos deixar de considerar um ponto de confluência entre os dois empreendimentos culturais: em ambos os casos a constituição do acervo bibliográfico não deixa de ser o resultado de uma escolha muito bem arquitetada, seja por impressores franceses independentes ou pelos súditos ilustrados do

33 VILLAS-BOAS, Manuel do Cenáculo. Apud DOMINGOS, Manuela. "A primeira biblioteca pública portuguesa..., Op. Cit., p. 62. (Grafia do Original).

${ }^{34}$ CURTO, Diogo Ramada. "Mercado e gentes do livro no século XVIII". In: . Cultura Escrita. Lisboa: ICS, Imprensa de Ciências Sociais, 2007. p. 208.

${ }_{35}$ CHARTIER, Roger. "Do livro à leitura”. In: CHARTIER, R. Práticas de leitura. Trad. Cristiane Nascimento. São Paulo: Estação Liberdade, 1996. p. 99.

${ }^{36}$ Ibid., p. 100. 
governo português, cuja responsabilidade se delineou em torno da nova política impressa que ocorria concomitantemente à reestruturação da biblioteca régia.

De acordo com o pesquisador Diogo Ramada Curto, entre o final do século XVIII e o início do século XIX a "política do livro" na França e na Inglaterra buscava a conciliação entre a liberdade de escrita e de imprensa e a capacidade de consumo e formação de um amplo mercado de livros. Tal política, segundo o autor, garantia um maior progresso civilizacional, uma vez que a sociedade comercial permitiu a correspondência entre as mais diversas nações e partes do mundo com uma frequência jamais vista. Em relação aos escritores, ao mesmo tempo em que se emancipavam do conflituoso jogo do mecenato, passavam a depender dos livreiros e editores, "uma espécie de novo mecenas, mas desinteressado de qualquer tipo de adulação". Ademais, ao estarem mais direcionados para o grande público, os escritores tinham a possibilidade de se tornarem os "favoritos do povo soberano". ${ }^{37}$

Na prática, isso demonstrava uma importante mudança de comportamento dessas sociedades guiada pela Filosofia das Luzes: o homem dava os primeiros passos em direção à maioridade intelectual, apregoada por Immanuel Kant, em 1784. Ou seja, o uso público da razão passava a ser compreendido também pelo viés do olhar dos leitores para a literatura em particular, e a palavra impressa, em geral. Especialmente no caso lusitano, nessa tarefa o Estado foi o principal interventor, cabendo à monarquia o encargo de instruir e "civilizar" a nação através de uma política cultural que atendesse aos anseios e projetos governamentais. É justamente por esse prisma que a concepção da Biblioteca

37 CURTO, Diogo Ramada. "Mercado e gentes do livro..., Op. Cit., p. 206. 
pública como um novo espaço laico do conhecimento e de acesso à sociedade letrada ganhava maior sentido. Afinal, como já bem definiu Roger Chartier, na tradição a biblioteca é sinal de um saber ou de um poder. ${ }^{38}$

Se ao longo de duas décadas (1775-1795) a primeira Biblioteca Pública da Corte sofreu avanços e retrocessos ${ }^{39}$, não podemos nos esquecer que o espaço também serviu como base fundamental para a fundação de sua congênere, em 1796. Nossa discussão situa-se precisamente acerca da estruturação desta instituição - a Real Biblioteca Pública da Corte - tendo como foco a política governamental mariana e joanina. Uma das principais bases da ação real nesse novo locus de cultura foi deixar sua inspeção geral sob a responsabilidade do Ministro da Real Fazenda, à época, D. Tomás Xavier de Lima Teles da Silva, o Marquês de Ponte de Lima. ${ }^{40}$ Apesar de o papel do ministro da Real Fazenda ter sido "largamente indefinido até pelo menos 1812 " 41 , particularmente no que concernia à administração da biblioteca pública, sua colocação era, primordialmente, auxiliar e prever tudo o que considerasse conveniente ao progresso da biblioteca e, em última instância, da monarquia.

Quanto às diretrizes do Alvará, estas já definiam as linhas mestras do espaço. Vejamos:

Eu a Rainha faço saber aos que este alvará virem: que sendo um dos objetos que ocupam a Minha Real Consideração o cuidado de promover, eficazmente os progressos da Literatura Portuguesa, e conhecendo o quanto será útil e

38 CHARTIER, Roger. "Do livro à leitura... Op. Cit., p. 90.

39 DOMINGOS, Manuela. "A primeira biblioteca pública portuguesa... Op. Cit., p. 68-69.

${ }^{40}$ MARTINS, Ana Canas Delgado. Governação e Arquivos:... Op. Cit., p. 6.

41 Ibid., p. 6. 
vantajoso, para se conseguir este fim, o estabelecimento de uma Livraria Pública, a qual servirá como um tesouro de todas as Artes e Ciências, e aonde se achem com os livros mais preciosos da sua raridade, e estimação os monumentos mais respeitáveis das mesmas artes, e Ciências que constituam um riquíssimo depósito não só de conhecimentos humanos, mas também dos meios mais próprios para conduzir os homens a conseguirem a virtuosa sabedoria, que constitui a felicidade e tranquilidade pública dos Estados, e é inseparável da piedade da Religião: querendo Eu reduzir a efeito este importante objeto da Minha Real Consideração por um modo eficaz de que resulte o desejado fim do maior aproveitamento a que aspiram os meus vassalos, que se dedicam a louvável cultura das ciências, e das artes com honra sua, e da paixão em que nasceram. ${ }^{42}$

Com o afastamento de $\mathrm{D}^{\text {a }}$ Maria I por questões de saúde, desde 1792 o Império Português era conduzido politicamente sob a regência de fato do Príncipe Regente D. João (tendo, inclusive, este documento a sua chancela). Todavia, é mister advertirmos que a produção discursiva do alvará tem importantes questões simbólicas. Para além de ter sido publicado pela voz da Rainha o que o referencia como um projeto governamental situado nos limites do seu reinado (até porque D. João assume a regência institucionalmente apenas em 1799) -, o documento também nos coloca diante de uma questão capital para a monarquia portuguesa, mormente em tempos de crise: a constituição de uma biblioteca pública delineava explicitamente a relação entre a soberania política e a constituição de um lugar institucionalizado onde o conhecimento público aliado à memória real fosse preservado.

42 Alvará de criação da Real Biblioteca Pública da Corte. BNP. Seção de Reservados. Cód.10610. 
Ademais, a aquisição do conhecimento era considerada o meio fundamental no processo de conquista da sabedoria, sendo nítida a concepção governamental de livraria pública em que pesava a indissociabilidade entre política e religião, dois pilares fundamentais do absolutismo português. Entretanto, como bem sugere a pesquisadora Manuela Domingos, apesar de a biblioteca ser apresentada à sociedade como uma "instituição de cultura ao serviço de todos os vassalos de S.M Rainha $\mathrm{D}^{\mathrm{a}}$ Maria I", ${ }^{\prime \prime 3} \mathrm{o}$ acesso ao acervo foi restrito. "Não se tratava porém, - contrariamente às tradições das Bibliotecas europeias suas congêneres -, de colocar à disposição de sábios, eruditos ou curiosos os tesouros manuscritos e impressos, colecionados de modo mais ou menos ostentatório, de uma Biblioteca Real, tornada pública", analisa a autora. ${ }^{44}$ Portanto, é sob esta perspectiva que as determinações do Alvará ganham ainda mais sentido e nos ajudam a melhor compreender as peculiaridades do universo cultural letrado português, ainda tão marcado por valores aristocráticos da sociedade de corte em que pesava, por exemplo, a distinção dos lugares sociais.

O Alvará de 1796 é composto por nove ordens. Da estruturação das oficinas e uso da biblioteca, sendo este "perpetuamente destinado ao bem das Letras, em benefício contínuo dos meus vassalos" ${ }^{\prime 4}$, perpassando a organização da numerosa coleção de livros e a administração do espaço, o documento detalhava todas as funções administrativas e tramitações burocráticas referentes ao novo locus de cultura. A quarta ordem, por exemplo, exigia que "a dita Real Biblioteca vá sempre em um contínuo aumento, e digna reputação, e haja nela um cuidado nunca interrompido e

${ }^{43}$ DOMINGOS, Manuela. "Historial da Biblioteca Nacional... Op. Cit., p. 3.

44 Ibid. (Grifo do Original.)

45 Alvará de criação da Real Biblioteca Pública da Corte. BNP. Seção de Reservados. Cód.10610. 
um zelo vigilante, qual convém que haja em um estabelecimento tal" ${ }^{46}$ Dentre as nove ordens presentes no Alvará, a sexta em especial nos interessa, uma vez que trata do funcionamento interno da biblioteca e dos papéis exercidos por seus profissionais. $\mathrm{O}$ destaque dava-se para o Bibliotecário Maior, que seria o responsável por sua direção geral, devendo responder diretamente ao Ministro da Real Fazenda. Personagem fundamental dentro da estruturação e manutenção deste locus de cultura, um dos principais desígnios do Bibliotecário Maior era servir ao bem público "com utilidade e prontidão", primando, assim, pelo efetivo atendimento aos "estudiosos" que forem à biblioteca. ${ }^{47}$ Abaixo dele, encontramos o segundo bibliotecário, cujo dever era ajudar "o Bibliotecário maior no que necessário for", substituindo-o "na sua ausência e em seus impedimentos". 48

A análise detida dos decretos de nomeação dos dois agentes basilares da recém-fundada Real Biblioteca Pública da Corte - Antonio Ribeiro dos Santos, o Bibliotecário Mor, e Agostinho José da Costa de Macedo, o segundo bibliotecário - indica-nos que, muito provavelmente, a escolha desses sujeitos históricos pela governança portuguesa era sustentada por um rígido critério de seleção. Sobre as qualidades do Bibliotecário Maior, o aviso destacava que este deveria ser uma

[...] pessoa em quem concorram as circunstâncias de se ter amplos conhecimentos das mais depurada literatura, experiência, madureza e probidade, e que com o título de Bibliotecário Maior dela, tenha a seu cargo a Administração Geral, e Governo da referida Biblioteca, com quanto dela pertencer, e haja desempenhar louvavelmente um

\footnotetext{
46 Ibid.

47 Ibid.

48 Ibid.
} 
emprego de tanta consideração, e importância: havendo respeito a que na pessoa do Doutor Antonio Ribeiro dos Santos, Desembargador Ordinário da Caixa da Suplicação, concorrem com as referidas circunstâncias as boas provas que já tem dado do seu zelo, e préstimo nos lugares do meu Real Serviço. ${ }^{49}$

Como bem demonstra este decreto, a escolha de Antonio Ribeiro dos Santos (1745-1818) para assumir tão ilustre cargo na nascente Real Biblioteca Pública da Corte foi baseada especialmente em um critério de distinção: a sua biografia. Apesar de não ter linhagem nobre, sua trajetória intelectual o qualificava como homem de vasta erudição e retidão moral. ${ }^{50}$ Clérigo formado em Direito pela Universidade de Coimbra, onde também exerceu o magistério (1779 - 1795) e atuou como bibliotecário da Livraria do Estudo (1777-1796), sua grande projeção profissional nos meios ilustrados portugueses deu-se desde os tempos da política reformista pombalina, da qual foi um crítico contumaz; aspecto que, mais uma vez, o distinguia entre seus pares, sobretudo em tempos de viradeira. ${ }^{51}$ Nesse contexto, sua concepção política de viés tradicionalista defendia, na visão de José Esteves Pereira, uma "transformação do tipo reformista que, salvaguardando as estruturas do poder, permitisse uma maior intervenção

\footnotetext{
49 Decreto da Nomeação de Bibliotecário Maior da Real Biblioteca Pública da Corte na Pessoa do Desembargador Antonio Ribeiro dos Santos. BNP. Seção de Reservados. Cód.10610.

${ }^{50}$ DIAS, Luís Fernando de Carvalho. Algumas cartas do Doutor Antonio Ribeiro dos Santos aos seus contemporâneos. Separata da Revista Portuguesa de História. Tomo XIV. Coimbra, 1974. p. 417.

51 Sobre a "apreciação negativa do pombalismo" de Antonio Ribeiro dos Santos, ver a análise do historiador português José Esteves Pereira, autor da expressão acima referida. PEREIRA, José Esteves. O pensamento político em Portugal no século XVIII: António Ribeiro dos Santos. Lisboa: Imprensa Nacional Casa da Moeda, 1983. p. 118-124.
} 
social". ${ }^{2}$ Tal postura, na prática, convergia com as diretrizes políticas dos primeiros anos do governo mariano, pautada principalmente pela ampla valorização da religião católica. "A participação dos valores socialmente considerados e definidos pelo espírito zeloso do teólogo e do canonista, permitiam, sem perigo, a leitura cristã de uma visão mais aberta, experiencial, sem subversão dos fundamentos teológicos, políticos e jurídicos", contextualiza Pereira. ${ }^{53}$ Logo, tal situação o abalizava ainda mais aos olhos da realeza.

Sobre o tema da reforma pedagógica universitária, assim se expressava Ribeiro dos Santos em epístola para um amigo:

Meu amigo. Vem vossa carta Lamentando [sic] a decadência dos estudos acadêmicos, e pranteais a falta do Marquês de Pombal. Mas que havia ele fazer agora, se fez pouco no princípio? Se edificou um edifício ruinoso, como havia agora de o ter [sic] em pé? Deixai-me soltar meus sentimentos, ainda que vos pareçam paradoxo, e que sejam contra a opinião comum [...]. Cumpre ver as coisas por dentro. O Marquês não fez o que convinha fazer. Este Ministro apesar de tudo o quanto disseram dele os seus Panegiristas, não talhou um Plano útil, que honrasse a sua Nação e o seu século. ${ }^{54}$

Escrita na ocasião da morte de Pombal, esta missiva fazia uma crítica direta ao modo pelo qual o primeiro ministro de D. José tratou a expulsão dos jesuítas do Império Português: o furor em eliminá-los, demonstrando como estes haviam "estragado a Literatura Portuguesa, e que era necessário a Portugal novos esforços para restaurar outra vez as Artes e as Ciências", o que o

${ }^{52}$ Ibid., p. 194.

53 Ibid., p. 195.

54 SANTOS, Antonio Ribeiro dos. (31ª Carta). In: DIAS, Luís Fernando de Carvalho. Algumas cartas do Doutor... Op. Cit., p. 448-449. 
motivara a recusar toda a contribuição dessa ordem religiosa. Em outra carta, Santos reiterava esta política pombalina ressaltando sua pouca perspicácia em não preservar as pinturas e bibliotecas jesuíticas, as últimas consideradas por ele "as melhores do nosso Reino". Eis o seu lamento: “[...] dos Livros, uns furtaram-se, outros converteram-se em papelão na oficina de Pallerini [sic], aonde se viu se andar de rojo pelo chão, das pinturas umas se roubaram, outras se perderam, apodrecendo em lugares aonde nunca mais se cuidou" ${ }^{55}$ A importância do papel de Ribeiro dos Santos como crítico durante o governo de Pombal, justamente quando o ambiente cultural permitia um diálogo mais próximo com as Luzes é abordado pelo historiador José Esteves Pereira. Segundo ele, "Faltava, em plena liberdade de movimentos, organizar e sintetizar as coordenadas ideológicas que contestassem o pensamento veiculado por essas obras." Nesse contexto, alguns pensadores lusitanos, entre eles Ribeiro dos Santos, acompanharam de perto o que Pereira denominou de "vicissitudes da política cultural pombalina", sendo, dessa forma, comprometidos com o confronto e a crítica do pensamento heterodoxo. ${ }^{56}$

Homem de leis e letras de renome, Antonio Ribeiro dos Santos é uma importante figura política do reformismo ilustrado português. Neste trabalho nos interessa enfatizar notadamente a sua atuação como bibliotecário, uma vez que a estruturação da Real Biblioteca Pública da Corte como locus de cultura na monarquia portuguesa é nosso objeto de investigação neste item. Durante o tempo em que desempenhou o cargo em Coimbra, Ribeiro dos Santos reorganizou a livraria da Universidade, o que

\footnotetext{
55 Ibid. (62 ${ }^{\text {a }}$ Carta)..., p. 479.

56 PEREIRA, José Esteves. O pensamento político em Portugal... Op. Cit., p. 121 (Grifos Nossos).
} 
realizou no âmbito das reformas pombalinas, tendo como finalidade a promoção do progresso dos estudos. Ademais, elaborou a Minuta para o regimento da Livraria da Universidade de Coimbra, onde discutiu questões de disposição interna, tratamento documental e criação de catálogos. Além disso, propôs que os fundos da Livraria se tornassem públicos, sendo permanentemente ampliados e atualizados.

A instalação condigna dos livros, assim como a forma de escolhê-los, também foi tema de sua reflexão. Aqui, a ênfase dava-se para as bibliografias, jornais, efemérides, mercúrios e gazetas sem contarmos com as novas produções literárias. ${ }^{57}$ Tal opção deveu-se especialmente ao fato de Portugal tecer um importante diálogo com o movimento editorial estrangeiro, pautado pelo critério da atualidade. ${ }^{58}$ Já a sua devoção aos livros é o mote do poema Do Autor. Aos seus livros.

Salve, ó meus Livros, Livros escolhidos Por vossos próprios méritos sublimes, Minha saúde e vida, meus prazeres:

Mimos dos olhos meus, altas delícias Do meu esp'rito [sic], que vos ama terno:

Que seria de mim, se o iniquo fado Me forçasse a viver de vós ausente!

Mais adiante, exalta os Filósofos da Antiguidade e a Bíblia Sagrada, ambos tidos como dádivas para o aperfeiçoamento do espírito.

${ }^{57}$ http://www.uc.pt/bguc/DocumentosDiversos/AntonioRibeiroSANTOS. Acesso em: 14 set. 2012.

58 ARAÚJO, Ana Cristina. A Cultura das Luzes em Portugal. Temas e Problemas. Lisboa: Livros Horizonte, 2003. p. 72. 
Salve, imortais Filósofos, famosos,

Epítecto, Plutarco, Xenofonte,

Que as virtudes morais nos ensinastes.

E sobretudo salve, ó Livro Eterno

Das sublimes verdades, que benigno

O Céu por nosso bem mandou à terra, Farol luzente da carreira humana.

O diálogo com a produção do conhecimento pelas diversas nações também fez parte das transformações capitais da humanidade. Exaltá-los publicamente era, sem dúvida, a melhor maneira de agradecê-los.

Salve, vós outros todos das mais classes,

Das Nações várias, de diferentes Línguas, Que eu sempre muito amei, que aqui não posso

Um por um nomear, bem que sois ricos

De elegância e doutrina, salve todos,

Não uma, duas, três, porém, mil vezes;

E ouvi as preces, que eu por vós só faço:

Rogo aos Céus que depois que vos eu deixe,

Finado esses meus dias já cansados,

Passeis a doutas mãos, que vos estimem

Como eu cá sempre voz prezei amigo. ${ }^{59}$

Como amante da literatura pátria e universal, o experiente homem de letras assumia seu novo posto de Bibliotecário Maior com um salário no valor de $600 \$ 000$ réis. ${ }^{60} \mathrm{~A}$ despeito do bom rendimento, o bibliotecário contou com a ajuda de um seleto

\footnotetext{
59 SANTOS, Antonio Ribeiro dos. O Autor. Aos seus livros. In: CUNHA, Xavier. Antonio Ribeiro dos Santos. Bibliophilo. Lisboa: Imprensa L. da Silva, 1913. p. 25-27.

60 Decreto da Nomeação de Bibliotecário Maior da Real Biblioteca Pública da Corte na Pessoa do Desembargador Antonio Ribeiro dos Santos. BNP. Seção de Reservados. Cód.10610.
} 
grupo de súditos, que também estavam incumbidos de levar avante (com sucesso) o novo empreendimento real. A começar pelo Guarda-Mor, que seria responsável pela custódia e segurança da Real Biblioteca, assim como pela arrumação, asseio e a arrecadação dos móveis, instrumentos e papéis. ${ }^{61}$ Além dele, o espaço era composto por dois oficiais escriturários, cuja função destinava-se a "escrever nos diversos catálogos da Biblioteca nos Livros da Receita, e despesa na reformação e traslados dos manuscritos, de que a livraria deve enriquecer-se", servindo também em tudo o que dissesse respeito ao Cartório e escrituração da casa. Outros seis oficiais bibliógrafos seriam divididos pelas diversas salas e gabinetes da Biblioteca, a fim de subministrarem ao público às consultas do acervo real: livros, manuscritos e outros monumentos das Artes e Ciências, que se quisessem ver. Estes bibliógrafos ainda tinham o auxílio de seis ajudantes, cuja tarefa era a vigia constante das salas. Por fim, a Biblioteca tinha a proteção de um porteiro, além do apoio de um agente, responsável pela diligência dos negócios externos relativos à Biblioteca e suas oficinas. ${ }^{62}$ Mesmo com a constante ajuda de diversos funcionários, durante os 20 anos (1796-1816) em que esteve à frente da direção da Real Biblioteca Pública da Corte, Antonio Ribeiro dos Santos realizou um trabalho hercúleo, mormente se considerarmos as dramáticas condições históricas em que se efetivou esse empreendimento cultural.

Na década de 1790 iniciavam-se os graves desdobramentos políticos advindos do processo revolucionário francês no Velho Mundo e, neste contexto, a situação de Portugal na diplomacia europeia tomava novos rumos. Desde a Campanha do Rossilhão

\footnotetext{
${ }^{61}$ Alvará de criação da Real Biblioteca Pública da Corte. BNP. Seção de Reservados. Cód.10610.

${ }^{62}$ Ibid.
} 
$(1793)^{63}$, a tradicional neutralidade portuguesa foi visivelmente ameaçada. A aliança militar que a Rainha travara com a Coroa espanhola converter-se-ia, dois anos depois, em um difícil xadrez político. Em meados de 1796, a assinatura do Tratado de Santo Idelfonso ${ }^{64}$, se selava a aproximação entre França e Espanha, também colocava Portugal em grandes dificuldades. Ou seja, a Península Ibérica ficava ainda mais vulnerável tornando-se, na análise de Jorge Pedreira e Fernando Costa, "um palco possível para o conflito entre a aliança franco-espanhola e a Inglaterra." ${ }^{65}$ Se Madri era, agora, explicitamente inimiga de Londres; Lisboa não o era: muito pelo contrário, desde o início do século XVIII a monarquia lusitana contava com a proteção militar britânica. ${ }^{66}$

Portanto, foi em meio às intrincadas manobras diplomáticas da Coroa Portuguesa que Antonio Ribeiro dos Santos deu início à nobre função. Por possuir um amplo olhar sobre o funcionamento de uma biblioteca, seu projeto cultural priorizava a divisão do acervo com foco na organização por temas e boa utilização do espaço. A livraria foi arranjada em dez seções - História,

\footnotetext{
63 A Campanha do Rossilhão (1793 a 1795) foi uma campanha militar em que Portugal aliou-se à Espanha e Inglaterra, contra a França revolucionária. Nesta ação militar, Portugal, o exército lusitano contribuiu homens que ficaram sob o comando do general britânico John Forbes.

${ }^{64}$ Tratado assinado entre os soberanos de Portugal e Espanha (1777), em Santo Ildefonso (Espanha), que de certa maneira reafirmava os pontos constantes do Tratado de Madrid. Os dois países acordaram no estabelecimento dos limites das suas colónias na América do Sul. Portugal cedeu a colônia do Sacramento, as missões da margem esquerda do Rio Uruguai e a soberania sobre o Rio da Prata. A Portugal foi restituída a Ilha de Santa Catarina (Brasil). Disponível em: <http:// www.infopedia.pt/\$tratado-de-santo-ildefonso> Acesso em: $01 \mathrm{dez} .2012$.

65 PEDREIRA, Jorge; COSTA, Fernando Dores. D. João VI... Op. Cit., p. 66.

${ }^{66}$ FALCON, Francisco José Calazans. "O império luso-brasileiro e a questão da dependência inglesa - um estudo de caso: a política mercantilista durante a época pombalina, e a sombra do tratado de Methuen”. In: Nova economia. Belo Horizonte: UFMG, Departamento de Ciências Econômicas, v. 15, n.2, 2005. p. 11-34.
} 
Belas Letras, Ciências Naturais e Artes, Ciências Civis e Políticas, Ciências Eclesiásticas, Poligrafia, Manuscritos e Antiguidades ${ }^{67}$ sendo ainda equipada com a constante atualização das novas produções científicas e culturais. Quanto ao acervo, destacavam-se a Biblioteca da Real Mesa Censória e o fundo da extinta Academia Real de História. ${ }^{68}$ Sobre a herança da Real Mesa Censória, Manoela Domingos considera-a "uma pesada carga" que foi assimilada ao longo dos anos sendo, posteriormente, convertido em um "grande tesouro", uma vez que revelava impressos preciosos do início da tipografia, ou ainda manuscritos posteriormente analisados como de grande relevância e originalidade. ${ }^{69}$

Ademais, as duas doações de colecionadores sui generis como a de Frei Manuel do Cenáculo e a dos Clérigos Regulares da Divina Providência (Teatinos) distinguiam o espaço entre as demais bibliotecas públicas do Reino, circunscritas aos conventos de S. Francisco e S. Domingos da Cidade e à Casa de N . Sr. ${ }^{a}$ das Necessidades. "Que sobressalto de consolação e alegria foi o meu quando vi pela primeira vez a lava Bíblia Sixtina [sic]. Este livro de ouro só poderia vir das mãos mil vezes benéficas e preciosas de V. Ex..", exclamava Ribeiro dos Santos diante da importante doação de Cenáculo. Segundo o bibliotecário, possuir um "tesouro literário" entre os destaques do acervo real servia para "fazer o esplendor e ornamento da Biblioteca, e aumentar-lhe infinitamente o seu valor". Tal fato, segundo ele, também contribuía para o enriquecimento da capital, que passava a contar com subsídios

${ }_{67}$ PEREIRA, José Esteves. O pensamento político em Portugal... Op. Cit., p. 76-77. ${ }^{68}$ Aviso de Sua Alteza em que mandou depositar na Real Biblioteca de Lisboa os Documentos, e Mss. da Academia Real de História Portuguesa. BNP. Seção de Reservados. Cód.10612.

69 DOMINGOS, Manuela. "Historial da Biblioteca Nacional..., Op. Cit., p. 9. 
cruciais para o novo impulso e energia aos progressos da literatura universal. ${ }^{70}$

Neste sentido, as cartas de Antonio Ribeiro dos Santos para Frei Manuel de Cenáculo entre os idos de 1796 e 1797 são uma riquíssima documentação do período em que podemos perceber vieses da atividade própria do bibliotecário real e da maneira de gerir e pensar a estrutura do novo locus de saber. ${ }^{71}$ Quanto à composição do acervo e sua respectiva organização, é notável a admiração do literato diante da experiência do "primeiro benfeitor e diretor" da Real Biblioteca Pública da Corte, mormente em dois aspectos: a catalogação das obras e a relação com o Estado. ${ }^{72}$ Vejamos, então, como o bibliotecário tentava conduzir o estabelecimento:

Já se extraiu em bilhetes o relatório de todos os livros, que V. Ex. ${ }^{a}$ tem mandado e deles se estão formando dois catálogos, um para a Biblioteca, e outro para se apresentar a Sua Alteza, pela Secretaria de Estado, porque assim melhor saiba, quão imenso cabedal de doutrina civil e sagrada lhe tem entrado pela capital. Estimará para então já ter recebido de V. Ex. ${ }^{a}$ as suas ordens e instruções, que já pedi por via do Sr. Sá ${ }^{73}$, sobre a natureza e forças do equivalente, que pode ser mais análogo e mais conforme aos interesses e satisfação de V. Ex. ${ }^{a}$, para eu saber, por que maneira devo fazer a Sua Alteza a apresentação do catálogo e cumprir para com V. Ex. ${ }^{a}$ os ofícios de servidão, em que estou empenhado por tantos títulos. ${ }^{74}$

\footnotetext{
${ }^{70}$ Cartas de Ribeiro dos Santos (Bibliotecário Real) de 1796-1797. BNP. Seção de Reservados. Mss. 160, 80-84. Carta n. ${ }^{\circ} 80$.

71 Ibid. Mss. 160, 80-84.

${ }_{72}$ Ibid. Mss. 160, 80-84. Carta n. ${ }^{\circ} 84$.

${ }^{73}$ Muito provavelmente, Ribeiro dos Santos se refere a José Antonio de Sá, Desembargador português no período. Para maiores informações acerva de sua atuação pública, ver: <http://www.arqnet.pt/dicionario/sajoseant.html >. Acesso em: 02 out. 2012.

${ }^{74}$ Cartas de Ribeiro dos Santos (Bibliotecário Real) de 1796-1797. BNP. Seção de Reservados. Mss. 160, 80-84. Carta n. ${ }^{\circ} 80$.
} 
Em dezembro de 1796, Frei Manuel de Cenáculo enviava a Ribeiro dos Santos dez caixas de livros. ${ }^{75}$ Nessa remessa de doações, o destaque deu-se para a literatura oriental, que despertou o apreço do bibliotecário: estas, por sua raridade, seriam objetos de grande estima em qualquer biblioteca europeia. Além dessa distinta coleção, Cenáculo ainda oferecia "outras raridades da Antiguidade" e fazia uma doação em dinheiro. ${ }^{76}$ Todas essas ações visavam o enaltecimento do novo locus diante das demais bibliotecas do Velho Mundo e, em última instância, a elevação e força do Estado. Nas monarquias absolutas, tal qual o gesto de escritores quando faziam dedicatórias aos príncipes como forma de elevá-los diante do Céu e da Terra, as doações aparentemente desinteressadas ${ }^{77}$ de colecionares de renome também serviam ao mesmo propósito. Como bem salientou Roger Chartier, "Na imagem da relação entre o soberano e o escritor, o livro tomou o lugar do edifício sagrado, o autor o do fundador, e o rei o do Deus, do qual ele é a terra e o lugar-tenente" ${ }^{78}$ No caso da Real Biblioteca Pública da Corte, $\mathrm{D}^{\mathrm{a}}$ Maria I não foi apenas a fundadora do espaço; foi, antes, a sua principal mecenas. Não foi à toa, portanto, que em uma sala central os leitores se deparavam com a estátua pedestre da soberana; o que, na prática, simbolizava a filiação do locus à política cultural da rainha.

Neste universo de mercês e reverências cortesãs, Frei Manuel de Cenáculo aparecia como um importante orientador

\footnotetext{
75 PEREIRA, José Esteves. O pensamento político em Portugal... Op. Cit., p. 79.

${ }^{76}$ Cartas de Ribeiro dos Santos (Bibliotecário Real) de 1796-1797. BNP. Seção de Reservados. Mss. 160, 80-84. Carta n. ${ }^{\circ} 82$.

77 De acordo com José Esteves Pereira, "A oferta de Cenáculo não era desinteressada, em absoluto, como consta de um requerimento de Ribeiro dos Santos para D. Rodrigo de Sousa Coutinho, reiterando as doações iniciais da doação." PEREIRA, José Esteves. O pensamento político em Portugal..., Op. Cit., p. 80.

78 CHARTIER, Roger. “O príncipe, a biblioteca e a dedicatória..., Op. Cit., p. 186.
} 
político e intelectual de Ribeiro dos Santos, ajudando-o a valorizar o seu capital intelectual e simbólico diante da realeza. Sob esse prisma, o religioso cedeu os seus catálogos ao bibliotecário da nova instituição e foi por ele publicamente reverenciado. "Os catálogos que V. Ex. a foi servido mandar-me dos livros, que tem destinado da sua riquíssima livraria para a Real Biblioteca Pública desta Corte, vieram aumentar sobremaneira o conceito que formava à muitos tempos dos imensos trabalhos, e aquisições de literatura de V. Ex. ${ }^{\text {"” }}$, agradecia o homem de letras. ${ }^{79}$

Como pudemos notar, a digníssima tarefa de organização e classificação dos livros reais foi intrínseca à troca de saberes em âmbito intelectual assim como à experiência política desses sujeitos, que deveriam conhecer profundamente as vicissitudes do Reino para, então, assumirem um cargo de tamanha responsabilidade. Em especial no caso de Ribeiro dos Santos, a sua polêmica trajetória dentro da Universidade de Coimbra é um importante demonstrativo do seu intenso interesse pela reforma pedagógica. ${ }^{80}$ Além disso, os cargos de censor régio, Comissário da Junta da Diretoria Geral dos Estudos do Reino (1799), Desembargador (1800), Deputado da Nova Junta do Código Militar Penal (1802) e Deputado da Mesa de Consciência e Ordens (1802) nos mostram que, aos olhos da realeza, Ribeiro dos Santos tinha todos os atributos de um súdito fiel, sendo, ainda, um homem de ampla versatilidade intelectual à altura de ser conselheiro do Príncipe Regente, como de fato o foi, a partir de 1802.

Foi dentro dessa concepção que entre os anos de 1796 e 1802 a Coroa Portuguesa investiu maciçamente na ampliação do

\footnotetext{
79 Cartas de Ribeiro dos Santos (Bibliotecário Real) de 1796-1797. BNP. Seção de Reservados. Mss. 160, 80-84. Carta n. ${ }^{\circ} 83$.

${ }^{80}$ Sobre sua trajetória coimbrã ver PEREIRA, José Esteves. O pensamento político em Portugal... Op. Cit., p. 13-74.
} 
acervo. Em maio de 1798, por exemplo, o Mordomo-Mor ordenava que Ribeiro dos Santos despendesse até 1:200\$ réis (um conto e duzentos mil reis) na compra de livros necessários para o enriquecimento do espaço. ${ }^{81}$ Quatro anos depois, em meados de 1802, o Príncipe Regente estabelecia a quantia de 1:600\$ réis (um conto e seiscentos réis), tendo como meta a aquisição de livros e jornais. As razões para as novas conquistas foram assim delimitadas:

Querendo aliviar a falta que há de fundos na Real Biblioteca desta Corte, para a compra e subscrição de obras periódicas, outros livros, que ministrem aos meus fiéis vassalos o conhecimento das úteis descobertas que se encontram em muitos anais e jornais literários, e científicos que se costumam publicar nas cortes mais polidas da Europa, hei por bem que no Meu Real Erário se pague anualmente pelo cofre do subsidio literário um conto e seiscentos mil réis; que sou servido consignar para as despesas dos ditos jornais, e livros, de que a mesma Biblioteca deve fazer aquisição. ${ }^{82}$

O decreto era dirigido a Dom Rodrigo de Souza Coutinho, então Presidente do Real Erário e também ministro encarregado da inspeção da Biblioteca da Corte. Como podemos notar, se o discurso real enfatizava a carência das obras, o fazia por uma ótica comparativa em relação à Europa do norte, considerada o berço das Luzes no século XVIII. Ademais, a educação dos súditos da monarquia também era foco de todas as atenções da realeza. Em Elementos da Civilidade e da Decência, para instrução da

\footnotetext{
${ }^{81}$ Aviso que ordena se possa comprar até 1:200\$réis de Livros. BNP. Seção de Reservados. Cód. 10610.

${ }^{82}$ Decreto em que S. Alteza Estabelece a quantia de um conto e seiscentos mil réis para a compra de livros e jornais. BNP. Seção de Reservados. Cód. 10612.
} 
mocidade de ambos os $\operatorname{sexos}^{83}$, um dos manuais de bom comportamento da sociedade cortesã da época, a relação entre leitura e conversação era estabelecida como um meio primordial para a educação da razão e dos sentidos.

A História e as Belas Letras devem ser o tesouro, onde devemos ir prover-nos das coisas, que ornam o nosso espírito para entreter uma conversação com agrado. No estudo da História e das Belas Letras acharemos o útil, e o agradável. Que poderoso motivo não é esse para obrigar um mancebo à aplicação delas! Que melhor matéria poderia ele escolher? ${ }^{84}$

Mais do que elevar a História e as Belas Letras como os dois grandes pilares do conhecimento, a obra ainda tinha um forte caráter pragmático, ensinando aos seus leitores os caminhos e vieses para a aquisição das 'luzes', ou na expressão de Immanuel Kant, do uso público da razão. Se as notícias adquiridas tinham o poder de desembaraçar as faculdades da alma, era, contudo, necessário que o aprendiz soubesse digeri-las para, assim, evitar cometer erros sobre os princípios do bom, tomando o falso pelo verdadeiro. ${ }^{85}$ Não por acaso, esse processo pedagógico esteve muito próximo ao conceito de crítica que vigorava na Europa no século XVIII, cujo significado geral, segundo Reinhart Koselleck, estava vinculado "à arte de julgar, e, portanto, de distinguir". ${ }^{86}$

\footnotetext{
${ }^{83}$ [Anônimo] Elementos da Civilidade e da decência, para instrução da mocidade de ambos os sexos: traduzidos do francês em vulgar. Lisboa: Tipografia Rollandiana, 1801, s/n. Com Licença do Desembargo do Paço.

84 Ibid., p. 217-219.

${ }^{85}$ Ibid., p. 219.

${ }^{86}$ KOSELLECK, Reinhart, Crítica e Crise: uma contribuição à patogênese do mundo burguês. Tradução de Luciana Villas Boas Castelo Branco. Rio de Janeiro: Ed. Uerj: Contraponto, 1999. p. 93.
} 
Particularmente em relação ao universo português em fins do Setecentos e princípios d'Oitocentos, o historiador José Augusto dos Santos Alves nos chama a atenção para as transformações de postura política da sociedade lusitana. "Os cidadãos interessados na coisa pública, podem desde logo optar por uma atitude crítica e pelo uso público da palavra como formas de legitimação política, econômica ou social, antes recusadas no espaço público representativo", analisa o autor. ${ }^{87} \mathrm{Ou}$ seja, esta nova concepção de espaço público em formação foi intrínseca à ascensão de uma esfera crítica em que a troca de opiniões e discussões emergia também e, sobretudo, das mudanças ocorridas nas práticas culturais. E é por este prisma que consideramos a biblioteca como um importante locus de produção do conhecimento que possibilitava múltiplas leituras e reflexões acerca de uma realidade em constante mutação. Como bem conceitua Roger Chartier, "A leitura não é somente uma operação abstrata de intelecção; ela é engajamento do corpo, inscrição num espaço, relação consigo e com os outros". 88

Apesar da crise do sistema absolutista na Europa, cuja dimensão ganhava maiores proporções à medida que se acentuava o processo revolucionário na França, a Coroa portuguesa empenhava-se em dar continuidade à política cultural da Livraria Pública da Corte, realizando-a, inclusive, como uma maneira de manter-se politicamente estável diante de países como França, Inglaterra e Espanha. Esta postura é o que nos indica o aviso de 30 de Março de 1803, que colocava em pauta o importante papel dos ministros Plenipotenciários do Príncipe Regente

\footnotetext{
87 ALVES, José Augusto dos Santos. A opinião... Op. Cit., p. 25

${ }^{88}$ CHARTIER, Roger. A ordem dos livros. Leitores, autores e bibliotecas na Europa entre os séculos XIV e XVIII. Tradução Mary Del Priori. Brasília: Editora da Universidade de Brasília, 1999. p. 16.
} 
residentes nas Cortes estrangeiras. A partir de então, estes homens de Estado da Coroa Portuguesa também atuariam como agentes culturais, tendo como responsabilidade a "abertura das correspondências literárias que se farão necessárias para a aquisição de bons livros, de que carecia prover-se a Real Biblioteca Pública de Lisboa". ${ }^{89}$ Não obstante a pouca variedade de obras que Ribeiro dos Santos tentou suprir ao longo de vinte anos (1796-1816), Manoela Domingos nos adverte que o estabelecimento assumiu-se como "lugar privilegiado da ostentação erudita da realeza”, mostrando-se, dessa forma, mais aberto aos interesses do Estado e da sociedade letrada. ${ }^{90}$

A atuação do então Ministro dos Negócios Estrangeiros e da Guerra, Antonio de Araújo de Azevedo, entre maio de 1805 e janeiro de 1806 também demonstra a mesma política de Estado no que tange à aquisição de livros. Neste período, Araújo negociou com o embaixador português em Londres, D. Domingos de Souza Coutinho, o transporte de sua livraria particular deixada em Haia, Holanda, quando da sua permanência no cargo de ministro plenipotenciário da monarquia portuguesa (17901799). ${ }^{91}$ Mesmo que o caso refira-se a uma biblioteca particular, os trâmites diplomáticos enfrentados para a condução do acervo até Lisboa compõem um episódio importante da Coroa lusitana, especialmente se considerarmos as personalidades envolvidas. Como sabemos, Azevedo e Coutinho situavam-se em polos

\footnotetext{
89 Aviso em que se determina se abra as correspondências com os Ministros de S.A residentes nas cortes estrangeiras. BNP. Seção de Reservados. Cód. 10612. p. 31.

90 DOMINGOS, Manuela. "Historial da Biblioteca Nacional..., Op. Cit., p. 8.

91 Para informações detalhadas sobre esse a atuação política de Azevedo neste período, ver: PINHEIRO, Andréa de Souza; MUNIZ, Luciana. "Antônio de Araújo de Azevedo, o Conde da Barca: política, ciências e saberes na biblioteca de um diplomata português”. Disponível em: <http://bndigital.bn.br/200anos/ araujense.html>. Acesso em: 7 fev 2011.
} 
ideológicos divergentes, sendo o primeiro conhecido na Corte como o representante do "Partido Francês", e o segundo assumidamente anglófilo. ${ }^{92}$

$\mathrm{Na}$ correspondência de 02 de maio, Araújo informava a Coutinho sobre o pedido que fizera ao Príncipe Regente no qual requeria "facilidades" para solicitar junto ao Governo Britânico um Salvo Conduto para os caixotes que constituíam a livraria, rogando-lhe que estes não sofressem "embaraço algum no seu trânsito", vindo igualmente em "Navio neutro". ${ }^{93}$ Apesar de Coutinho ter conseguido a proteção inglesa para o transporte das 62 caixas contendo livros, minerais, estampas e cartas $^{94}$, em início de agosto o navio havia sido tomado (e depois liberado) pelos britânicos. Como ainda não tinha notícias sobre a localização dos seus pertences, Azevedo utilizou-se, mais uma vez, da intervenção pessoal de D. João na negociação. Segundo o ministro, o Príncipe Regente determinava que "[se] faça diligência por saber se as ditas Caixas que me pertencem estarão já desimpedidas, e quando não estejam o representará a esse Governo que espero não fará a menor dificuldade em as mandar [sic] pôr livres". ${ }^{95}$ Dias depois, seu correspondente em Amsterdã o deixava ciente sobre o paradeiro da embarcação, que se encontrava em Yarmouth; porém, mesmo já conhecendo o paradeiro de seus pertences Araújo se mostrava muito receoso de haver alguma baldeação que pudesse atrapalhar ou mesmo adiar o envio. Por isso, apelava à Coutinho que fizesse "todas as diligências para haver a menor danificação

\footnotetext{
92 Sobre essa discussão acerca das posturas diplomáticas divergentes, ver PEDREIRA, Jorge; COSTA, Fernando Dores. D. João VI... Op. Cit., p. 88-91.

93 ANTT. Ministério dos Negócios Estrangeiros. Cx.152. Carta n. 61.

${ }^{94}$ Ibid. Carta n. 79.

95 Ibid. Carta n. 79.
} 
possível nos meus efeitos"96 que podiam ser identificados pela "marca AA", as iniciais do seu nome. ${ }^{97}$

Enfim, em janeiro de 1806 encerrava-se o episódio tendo Antonio de Araújo de Azevedo reavido a sua livraria. No entanto, para que o ministro recuperasse um objeto cultural que lhe era tão caro, foi necessário que alguns personagens capitais da diplomacia europeia se envolvessem no caso. Da parte britânica, para além de Souza Coutinho, Azevedo teve a ajuda de Lord Strangford e Lord Mulgrave ${ }^{98}$; já do lado francês, contou com a autorização de Junot, que lhe concedeu o passaporte para o livre trânsito da livraria. ${ }^{99}$

Neste intricado processo, o ministro fez questão de destacar que seu acervo possuía dois retratos de figuras ilustres da monarquia portuguesa, sendo um do Marquês de Pombal e outro de D. Luis da Cunha. ${ }^{100}$ Ao final do imbróglio, Azevedo não poupou agradecimentos "às pessoas públicas que nessa Corte [de Londres] se interessaram a favor desta restituição" ${ }^{101}$ Convém lembrar que todas essas estratégias retóricas utilizadas pelo ministro lusitano eram próprias à cultura diplomática da época, da qual era um dos mais destacados agentes. Nesse sentido, Antonio de Araújo tentava deixar claro que a sua influência como homem de Estado, assim como o prestígio da monarquia lusitana com as Coroas francesa $\mathrm{e}$ britânica, tinham sido as duas grandes razões para o sucesso dessa difícil missão, sobretudo em tempos de guerra.

Enquanto isso, Antonio Ribeiro dos Santos compunha os vários Catálogos da Livraria Pública, uma experiência crucial

\footnotetext{
${ }^{96}$ Ibid. Carta n. 83.

97 Ibid. Carta n. 83.

${ }_{98}$ Ibid. Carta n. 88.

99 Ibid. Carta s/n.

100 Ibid. Carta n. 83.

101 Ibid. Carta n. 86.
} 
para que o locus alcançasse o esplendor objetivado pela monarquia. ${ }^{102}$ A composição desses manuscritos, contudo, envolvia uma complexa rede de agentes circunscritos ao mundo da palavra impressa: do contato com correspondentes, livreiros e impressores em âmbito internacional às escolhas dos livros a serem adquiridos e cuidadosamente organizados, o bibliotecário ia tecendo importantes relações sócio-políticas nesse múltiplo circuito de informações, ao mesmo tempo em que dava forma a um amplo e novo mosaico de obras. ${ }^{103}$

A classificação dos títulos impressos que compunham (ou comporiam) o acervo da biblioteca é uma questão que deve ser reverenciada. Ao analisar a inserção e impacto dos livros religiosos na Colônia no mesmo período, a historiadora Leila Mezan Algranti destacou a complexidade dessa atividade. "[...] se o ato de classificar é por si algo que depende dos critérios da seleção

\footnotetext{
${ }^{102}$ Nesta pesquisa trabalharemos com o seguinte Catálogo: SANTOS, Antonio Ribeiro dos. Lista de livros e periódicos estrangeiros que a Biblioteca Nacional de Lisboa necessita adquirir de novo ou para completar colecções. 1796-1816. BNP. Seção de Reservados. Cód. 565. Esta opção deveu-se, principalmente, pelo fato do respectivo manuscrito tratar de diversas coleções de naturezas diferentes da Real Biblioteca Pública da Corte ao longo de todo o período em que Ribeiro dos Santos atuou como bibliotecário, isto é, entre os anos de 1796 e 1816. A íntegra deste documento pode ser conferida ao final desta teste (Anexo II). Os demais Catálogos conhecidos são: Catálogos de livros escolhidos (BNP. Seção Fundo Geral. Cód. 4622,Cód.4625, Cód.4626 e Cód.4627), Catálogos de livros para sortimento da Real Biblioteca de Lisboa e um Catálogo de livros que se devem mandar vir de fora (BNP. Seção Fundo Geral. Cód. 4631), Bibliotecas de legislação (BNP. Seção Fundo Geral. Cód. 4628), e, por fim, Biblioteca de história política de Portugal (BNP. Seção Fundo Geral. Cód. 4629).

103 Sobre a complexidade desse circuito de informação no mundo luso-brasileiro ver BELO, André, As Gazetas e os Livros... Op. Cit.; LISBOA, João Luís Lisboa, "News and newsletters in Portugal". In: Enlightement, Revolution and the periodical press, Voltaire Foundation, Oxford, 2004; LISBOA, João Luís; MIRANDA, Tiago C.P. dos Reis e OLIVAL, Fernanda, Gazetas Manuscritas da Biblioteca Pública de Évora (1729-1731), vol. 1. Lisboa: Edições Colibri, 2002; MEIRELLES, Juliana Gesuelli. Imprensa... Op. Cit.
} 
adotada e estes podem levar em consideração vários elementos, dificilmente encontraríamos dois sistemas classificatórios iguais para os livros religiosos" 104 , conceitua a autora. As diferenças nos sistemas classificatórios apontadas por Algranti constituíram um problema dos homens de letras ${ }^{105}$ do Antigo Regime e, portanto, se estendiam para todos os tipos de livros independentemente da temática.

Considerando-se que a produção e classificação de um Catálogo de obras impressas é um ato de poder, a personificação dessa atividade na figura de um homem de letras de destaque no caso Antonio Ribeiro dos Santos - representava, na prática, a exaltação da sua concepção particular de leitura, sobretudo em tempos de Encyclopédie onde a disputa pelo prestígio intelectual tornara-se moeda de grande valia dentro do conflituoso universo da República das Letras. No caso do renomado bibliotecário régio, ao colocar o seu saber a público este não apenas ratificava a sua força intelectual, mas especialmente atribuía os seus hábitos de leitura para os leitores em geral. E como bem demonstrou o pesquisador Rodrigo Bentes Monteiro ao estudar os folhetos de Diogo Barbosa Machado, ao escolherem e organizarem as suas coleções, esses homens de letras tinham seus critérios de relevância. ${ }^{106}$ A tentativa de desvendá-los, talvez, nos ajude a adentrar em

104 ALGRANTI, Leila Mezan. Livros de Devoção... Op. Cit., p. 179.

105 Utilizamos o conceito de homem de letras defendido pela filósofa Hannah Arendt. Segundo a autora, "os homens de letras se educaram e cultivaram suas mentes em uma reclusão pela qual optaram livremente, colocando-se portanto a uma distância calculada, tanto do social como do político - dos quais de qualquer sorte, haviam sido excluídos -, a fim de observá-los em uma perspectiva apropriada." ARENDT, Hannah. Da Revolução... Op. Cit., p. 33-36.

106 MONTEIRO, Rodrigo Bentes. "Portugal e as conquistas ultramarinas nos folhetos de Diogo Barbosa Machado" Disponível em: <http://www2.iict.pt/index.php?idc=102\&idi=13077>. Acesso em: 15 out. 2012. 
vieses relevantes da concepção de leitura desses sujeitos do final do século XVIII e princípios do século XIX. ${ }^{107}$ Por outro lado, não podemos nos esquecer do amplo aparato censor vigente no Império Português que tinha na Inquisição, no Ordinário e no Desembargo do Paço a sua base institucional desde fins de $1794 .{ }^{108}$ Como bem analisou Algranti, o sistema de censura da sociedade de corte luso-brasileira da segunda metade do século XVIII era regido pela premissa da desigualdade, em que pese o fato de algumas leituras (geralmente as tidas como proibidas) serem consideradas boas para alguns e não para outros. ${ }^{109}$ Nesse contexto, por mais que Ribeiro dos Santos, por sua posição privilegiada, tivesse o beneplácito real para ler as obras consideradas sediciosas, seu critério de relevância dos livros e periódicos que compuseram o acervo da Biblioteca Pública Real da Corte, foi guiado dentro dos limites considerados aceitáveis pela realeza.

A difícil tarefa de classificação das obras também pode ser apreendida na análise de um de seus Catálogos, cujo critério de

\footnotetext{
107 DARNTON, Robert. O Beijo de Lamourette:... Op. Cit.

108 Para informações mais detalhadas referente ao aparato censor da monarquia portuguesa conferir a Introdução desta tese além das seguintes obras. ALGRANTI, Leila Mezan. Livros de Devoção... Op. Cit.; NEVES, Lúcia Maria Bastos P. "Comércio de livros e censura de ideias: a atividade dos livreiros franceses no Brasil e a vigilância da Mesa do Desembargo do Paço (1795-1822)”. In: Ler História, 23, 1992; VILLALTA, Luiz Carlos, "Censura literária e inventividade dos leitores no Brasil Colonial”. In: TUCCI, Maria Carneiro (Org.), Minorias Silenciadas: História da Censura no Brasil. São Paulo: Edusp, 2002.

109 ALGRANTI, Leila Mezan. Livros de Devoção... Op. Cit., p. 173. De acordo com a autora, "Na segunda metade do século XVIII, muitos padres, mas também leigos, dirigiram-se ao monarca a fim de obter a desejada licença para ler obras proibidas. Geralmente as justificativas apoiavam-se no desejo de adquirir maior instrução relacionada com o exercício das profissões. Estudantes e bacharéis em leis, médicos e cirurgiões submeteram pedidos desse tipo e foram atendidos. Mas também fidalgos - burocratas de carreira no Ultramar - consideravam o privilégio de ler livros proibidos um sina de status distinção, assim sendo requeriam ao monarca licenças desse tipo." Idem.
} 
relevância priorizou os centros literários considerados de grande reconhecimento público na Europa Iluminista. Ou seja, a seleção dos títulos que interessavam ao bibliotecário adquirir, sendo estes considerados balizas importantes para o progresso das letras em Portugal, foi prioritariamente europeia e esteve circunscrita a seis locais, entre países e cidades. Espanha, França, Itália, Nápoles, Berlim e Inglaterra, nesta ordem, aparecem como os espaços de produção que mereciam ser reverenciados nas estantes da biblioteca.

Tal como Barbosa Machado em sua coleção de folhetos, em que predominava a "ordem entre os continentes", sendo que os títulos referentes “à Ásia, vêm antes de América e África, contrariando a lógica que destaca a importância do Brasil na conjuntura do século XVIII"110, Antonio Ribeiro dos Santos também hierarquizou os lugares com os quais dialogava: a Península Ibérica foi reverenciada pela Espanha na abertura do seu Catálogo, com um total de 32 publicações impressas consideradas de interesse para as estantes reais lusitanas. Depois, França e Itália, com 53 e 28 títulos respectivamente. Se a primeira era a "essência do espírito enciclopédico", na expressão de Franco Venturi ${ }^{111}$, a segunda era a grande referência da Antiguidade greco-romana, tão apreciada pelos europeus desde a Renascença. Neste particular, também podemos incluir Nápoles, que, juntamente com Milão, constituíram-se nos principais centros do Iluminismo italiano a partir de $1760 .{ }^{112}$ Por fim, nesse movimento sobressaíram-se Berlim e Inglaterra que, para além de terem sido grandes apreciadores e admiradores do movimento enciclopédico, também brilhavam como centros filosóficos. Da Grã-Bretanha, por exemplo,

${ }^{110}$ MONTEIRO, Rodrigo Bentes. "Portugal e as conquistas..., Op. Cit.

111 VENTURI, Franco. Utopia e Reforma no Iluminismo. Trad. Modesto Florenzano. Bauru, SP: EDUSC, 2003. p. 226.

112 Ibid., p. 233. 
advinha a ideologia deísta, que saiu da Ilha para dominar o continente. Sendo Ribeiro dos Santos um antideísta ferrenho ${ }^{113}$, não é de se espantar que a Inglaterra tenha sido relegada ao último centro intelectual de seu Catálogo, tendo tido os periódicos britânicos maior importância do que as obras clássicas do país.

Em relação às obras de forma geral, o literato faz comentários sobre os títulos que constituíam o acervo ou que deviam ser comprados. Analisa-os com um discurso detalhado - informando o local e ano da publicação, além de, em alguns casos, fazer uma pequena descrição da obra, caracterizando-a. Para além de facilitar o seu próprio trabalho de catalogação interna, esta postura do bibliotecário também tinha o intuito de promover as atividades dos seus ajudantes, quando entravam em contato com os leitores do espaço, fossem eles frequentadores eventuais ou assíduos. Com as informações minuciosas do acervo, os agentes da biblioteca podiam direcionar melhor a pesquisa e os interesses do seu público leitor.

Nesse sentido, a análise do historiador João Luís Lisboa sobre as bibliotecas públicas em Portugal entre 1780 e 1820 nos é muito elucidativa. "Não há dúvida de que estas bibliotecas eram frequentadas, mas normalmente dentro de um espírito de 'trabalho' e de 'investigação"'114, esclarece o autor. Logo, é dentro desse paradigma que um leitor pedirá uma novela para ler. "[...] em princípio [esse leitor] deseja conhecer algum tipo de literatura, ou algum autor, e não alguém que procure distrair-se ou

\footnotetext{
113 Sobre a concepção religiosa de Antonio Ribeiro dos Santos e a crítica ao deísmo, ver: PEREIRA, José Esteves. O pensamento político em Portugal... Op. Cit., p. 179-240.

114 LISBOA, João Luís. Ciência e Política. Ler nos finais do Antigo Regime. Lisboa: Instituto Nacional de Investigação Científica, Centro de História da Cultura, Universidade Nova de Lisboa, 1992. p. 44.
} 
entreter-se. É essa leitura que as bibliotecas facultam, e o público não poderá sair de um círculo de "estudiosos", laicos ou religiosos, conclui Lisboa. ${ }^{115}$ Nesse contexto, compreendemos melhor as escolhas temáticas de Antonio Ribeiro dos Santos. Vejamos, então, como classificou a lista de algumas Obras Periódicas de Espanha:

Memorial Literário o Bibliotheca Periódica de Ciências y Artes. (temos o tomo I., ano primeiro. Madri, em la Imprenta de Garcia e Comp. ${ }^{\text {a }}$. Octubre de 1801.);

Bibliotheca Española Economico_Política (É coleção de extratos, e se abriu por subscrição em 1802 e tem já saído seis pequenos cadernos, ou n ${ }^{\circ} \mathrm{s}$. [)].

Correio literário de Xeres (Começou em 1800, e subscreve-se em Madri na Casa de Esparza).

Semanário de Agricultura y Artes (Publicam-se por ordem Superior. Temos o tomo IX e X. Impressos em Madri em $4^{\circ}$ em 1801 na Imprenta de Villal Pando[)].

Mercurio de España Madrid: (Há m.tos anos que sai, e necessitamos de todos os tominhos [sic] que tem saído até agora [)].

Anales de Ciências Naturaes (Publicam-se por Ordem Superior, julgamos serem já 14 tomos [)].

Anales de Artes y Manufacturas por R. O. Reylli. ${ }^{116}$

Já para a "lista [rasurado] de alguns livros de Espanha que necessita a Real Biblioteca”, por exemplo, selecionou as seguintes obras:

Memorias Políticas, y Economicas sobre los frutos Commercio, Fabricas, y Minas de España, por D. Eugenio Lavruga 1792. (46 tomos de $4^{\circ}$ e talvez haverá mais).

D. Luiz Luniga. Plano de Antiguidades Espanolas [sic] (em casa de Castilla frente a las grades de S. Filippe).

${ }^{115}$ Ibid., p. 44.

116 SANTOS, Antonio Ribeiro dos. Lista de livros e periódicos estrangeiros... Op. Cit. BNP. Seção de Reservados. Cód. 565. 
Introduction a la Historia Natural y a la Geografia física de Espana por D. Guillermo Bowles. 1 tomo. $4^{\circ}$ [)].

Historia de Políbio Megapolitano traducida del Griego por D. Ambrosio Ruy Bomba. 3. V. $4^{\circ}$.

Obras Poéticas de Píndaro em Metro Castellano con el texto Griego y notas Críticas , por D. Fran.co Patricio de Berguiza. 12. ${ }^{\circ}$

Los diez libros de Diogenes Laercio sobre las vidas de los Filosofos traducidas del Griego por D. Jozé Ortiz. 2 V. $4^{\circ}$. Oraciones e Cartas de Socrates traducidas del Griego, y illustradas con notas por D. Antonio Ranz Ramanellos. $3 \mathrm{~V} .{ }^{\circ}{ }^{\circ}$ maior.

Examen de la possebilidad [sic] de fixar la significacion de los sinonimos de la língua Castellana, por D. Jozé Lopes de la Huerta. 1V. $8^{\circ}$.

D. Juan de la Reguera Val de tomar Resumem de la Historia Cronologica del Derecho y Leis de España. Tomos dez Fueros.

D. Rennan Lavaro de Dou Instituiciones del Derecho Publico Geral de Espana.

D. Dionizio Marcate e Dias . Leciones de Navegacion e Arte de la cria de Gusanos de Seda por Juan Lanes y Durval. 1 V.8. ${ }^{\circ}$

Elementos de Higiene trad. De Esteban Soustelle por D. Luiz Mexia.

D. Segismundo Malats. Elementos de Veterinarian el . Dissertacion sobre la explicacion y uso de um Maquina agramadera para agramar Canais e linos em $4 .^{\circ}$

Descripcion de las Maquinas de mas general utilidade que hay em el Real Gabinete de ellas en el Buen Retiro. V. 1.2.3.4.

Dicionario histórico de las Artes de la Pesca nacional por D. Antonio Sanez Reguard. 5. tomos $4^{\circ}$ maior.

Reflexiones sobre las Maquinas y Maniobras del uso de à bordo pr D. Francisco Ciscar. 1 tomo. $4^{\circ}$.

Memoria elemental sobre los nuevos pesos, $y$, medidas decimales fundados en la natureza por el mismo. Tratado de Navegacion por d. Joseph de Mendoza y Rios. 2V. $4^{\circ}$. 
Ensayos políticos econômicos y filosóficos del Conde de Rumtoro. Traduciodos por D. Domingos Aguero y Neyva. Elementos del Arte de tenir de Mr. Berthollet traduc. con addiciones D. Domingos Garcia Fernandes. 2V. $8^{\circ}$.

Ordenanzas Generales dela Armada Naval. 2 tomos. Fol. D. Jayme Bovells y D. Ignacio Lacaba. Curso completo de Anatomia.

Diccionario elemental de Farmacia por D. Manuel Hermandez de Gregorio 2 tomos. $4^{\circ}$.

Diccionario General de Medallas de D. Thomaz de Gulseme. $1773.6 \mathrm{~V} .4^{\circ}$.

Casto Gonzales Instrucciones Antiquario Lapidarias, traducidas de la língua Toscana. Madrid 1794. 1 V. $4^{\circ} .^{117}$

Como podemos notar, o bibliotecário privilegiou as obras de História, Geografia, Política, Jurisprudência, Medicina, Letras (Literatura e Ortografia, com ênfase para os dicionários), e Ciência em geral. A natureza deste corpo documental assim como a intervenção de Antonio Ribeiro dos Santos na montagem do Catálogo e na classificação das obras, provavelmente obedeceu a uma tradição literária com dois polos [?] distintos: Portugal e Europa. No país, destacava-se a relevância do trabalho do bibliófilo Diogo Barbosa Machado, que teve um grande peso entre os homens de letras da segunda metade do século XVIII. Já no Continente, a classificação da Encyclopédie era a grande referência. ${ }^{118}$

A organização e classificação das obras da coleção de Barbosa Machado já deixava claro o eminente valor dado à palavra

117 Ibid.

118 Como bem salienta Robert Darnton, a classificação proposta pelos filósofos da Encyclopédie deixava claro que "a própria tentativa de impor uma nova ordem ao mundo tornou os enciclopedistas conscientes das arbitrariedades de toda ordenação." DARNTON, Robert. O grande massacre de gatos e outros episódios da história francesa, tradução de Sonia Coutinho. 4. ed. Rio de Janeiro: Ed Graal, 2001. p. 252. 
escrita; aspecto que a diferenciava das demais compilações do período, tão voltadas "para medalhas, moedas e outros vestígios materiais do passado."119 Para Monteiro e Caldeira, o destaque de tal postura dá-se, sobretudo, por expressar o predomínio da civilização da escrita, na acepção do historiador Fernando Bouza. Por ser o grande objeto da livraria de Diogo Barbosa Machado, a palavra impressa ganhava uma nova dimensão: estreitava-se o vinculo entre o poder e a tipografia, o que muito influenciou as escolhas de Antonio Ribeiro dos Santos na composição do acervo real.

Diferentemente da Espanha, a catalogação dos títulos da França foi separada em duas listas: livros e periódicos. Para o primeiro acervo, o foco esteve na lista "das continuações de que necessita a Biblioteca de Lisboa para completar as obras que já tem", sendo estas estruturadas em seis temas: 1 . História Civil e Política; 2. História Literária; 3. Filosofia e Artes; 4. Medicina em particular [sic]; 5. Poligrafia; e 6. Outras Obras de novo [sic]. Já o segundo, foi intitulado De Jornais e mais obras Periódicas que necessita a Biblioteca de Lisboa, sendo a prioridade os periódicos de História Natural, Arte e Ciência, Literatura e Política. Para a Itália, o bibliotecário fez uma classificação semelhante. Se o princípio foi a seleção temática - 1. História Literária; 2 . História Civil e Política; 3. Ciências e Artes; 4. Medicina em particular [sic]; e 5. Poligrafia - notamos duas importantes diferenças quando comparamos com o arranjo dos impressos franceses. A primeira delas refere-se à ordem dos temas (enquanto para França História Civil e Política aparece no topo da lista, para a Itália o destaque é dado à História Literária) e a segunda à classificação propriamente dita.

119 MONTEIRO, Rodrigo. Bentes; CALDEIRA, Ana Paula Sampaio. "A ordem de um tempo: folhetos na coleção Barbosa Machado” In: Revista TOPOI, v. 8, n. 14, jan.-jun. 2007, p. 78 (Grifo do Original). 
Para os livros franceses, Ribeiro dos Santos denominou as obras de "Filosofia e Artes", enquanto os livros italianos de categoria análoga foram categorizados como "Ciências e Artes".

Ambas as denominações, no entanto, respeitam a ordem classificatória do século XVIII, inclusive a veiculada na Encyclopédie, e, à época, eram consideradas sinônimos. Como bem contextualizou João Luís Lisboa, "A noção de Filosofia, se exclui a Teologia e Jurisprudência, inclui então como parte muito importante a chamada 'Filosofia Natural', onde cabiam as ciências da natureza". ${ }^{120}$ Esse tipo de leitura é tão valorizado no período que em 1815 a Gazeta de Lisboa anunciava um "jogo otimanente encadernado da Enciclopedia, ou Dicionário Geral das Ciências, Artes e Ofícios, por Diderot e d'Alembert" cuja edição, tida como "asseada e cômoda", era composta por 39 volumes, podendo ser compradas na loja de Livros de João Henriques, na Rua Augusta N.1. ${ }^{121}$ Em relação às outras produções impressas italianas de que necessitava a biblioteca, definiu-as como "coleções e extratos", sendo as obras de Nápoles divididas em "coleções" e "outras obras". Finalmente, se Berlim e Inglaterra também foram contempladas como grandes centros culturais, a catalogação de seus livros foi feita de forma mais geral. Para a cidade germânica, o bibliotecário selecionou obras de História, Ciências e Artes. Já para as obras inglesas compôs duas listas: a primeira, referente aos jornais, papéis e periódicos que precisavam ser adquiridos; e a segunda, alusiva aos livros especificamente.

É curioso observamos ainda as obras selecionadas pelo bibliotecário régio, independente dos espaços de produção. A ênfase do Catálogo foi circunscrita aos títulos impressos na se-

${ }^{120}$ LISBOA, João Luís, Ciência e Política... Op Cit., p. 91.

121 GL. 1815. n. 116. 
gunda metade do século XVIII, com especial destaque para os livros e coleções produzidos entre as décadas de 1770 e 1780. Essa perspectiva, contudo, não desviou seu interesse para os livros e periódicos veiculados na Europa durante a Idade Moderna. De Britannica Lingua Institutiones, obra de Joann Cambro publicada na Inglaterra em 1592 à coleção de extratos da Bibliotheca Española Econômico-Política, impressos na Espanha a partir de 1802, Ribeiro dos Santos procurou compor as estantes com referências clássicas. Nos títulos da Itália encontramos, por exemplo, a procura pela coleção de História Antiga, L'Abbate Viviani Collecione dell'Historici antiqui Herodoto Thucydides V. Vulgarizati, publicada em Roma, em 1790. Para a Espanha, uma das escolhas recaiu em Historia de Políbio Megapolitano traduzida do grego. Já em relação a França, Histoire del Academie Royale des Scciences de Paris apareceu como um dos destaques da categoria "Filosofia e Artes".

Essa atividade quase febril de Antonio Ribeiro dos Santos, que fazia da biblioteca inclusive seu lugar de descanso ${ }^{122}$, contribuiu sobremaneira para a institucionalização da palavra impressa no Brasil a partir de 1808, data em que a Corte portuguesa chegava à América. A fundação da Real Biblioteca do Rio de Janeiro, em 1811, assim como o trabalho do bibliotecário Luís Joaquim dos Santos Marrocos, entre os anos de 1811 e 1821, foram

\footnotetext{
122 Segundo o depoimento de Antonio Feliciano de Castilho, seu contemporâneo, "Era a biblioteca o íntimo retiro deste ermitão de Parnaso, fugida para longe das casas, posto que quietas e frescamente assentada em meio de muitas sombras, verduras e aromas do seu jardim, horta e pomares. Grandíssima cópia de livros, longamente procurados e custosamente juntos, e entre os quais se estremavam, no número e riqueza, os gregos, os romanos, e os antigos portugueses... Um Apollo de mármore, com a sua lira em punho parecia estar-se muito bem cabido no meio daquele seu alcaçar.[sic]". CASTILHO, Antonio Feliciano. Acerca da pessoa do Sr. Antonio Ribeiro dos Santos. In: A primavera, Lisboa, 1837, p. 325-326. Apud PEREIRA, José Esteves. O pensamento político em Portugal... Op. Cit., p. 83.
} 
altamente inspirados na sua congênere lisboeta e no mais dileto de seus funcionários, Ribeiro dos Santos. A compreensão desse diálogo interatlântico marcado pela trajetória de uma seleta coleção real que atravessou o Atlântico em três viagens distintas, tornando-se o primeiro acervo da nova instituição da corte, é o tema do próximo item.

\subsection{A nova Corte do Rio de Janeiro joanino: a Impressão Régia e o mundo dos livros}

Uma das grandes transformações ocorridas no Rio de Janeiro a partir de 1808 foi a introdução da tipografia. Com o nascimento da Impressão Régia deste lado do Atlântico, sancionada pelo decreto de 13 de maio de 1808, a sociedade fluminense passou a conviver cotidianamente com a circulação da palavra impressa. ${ }^{123}$ Dos decretos reais aos livros que "saíam à luz" ou se "achavam à venda" 124 , perpassando os almanaques, cartazes e a própria Gazeta do Rio de Janeiro, entre outros periódicos, os habitantes da nova capital do Império Português - a despeito da atuação dos censores - tinham ao seu alcance a possibilidade de

123 Peça fundamental no processo de comunicação interatlântica, intimamente associado à veiculação da propaganda do Estado e, consequentemente, à sustentação do Império Português nos dois lados do Atlântico, a Impressão Regia tinha numerosas funções que extrapolavam a impressão exclusiva dos papéis ministeriais e diplomáticos do serviço real de todas as repartições, como os alvarás, decretos e cartas régias. Ficava sob a sua responsabilidade também imprimir as obras de particulares, tanto quanto produzir e fazer circular a Gazeta do Rio de Janeiro.

124 As duas categorias das obras foram objetos de estudo da historiadora Maria Beatriz Nizza da Silva. Os livros que "saíam à luz" referiam-se aqueles produzidos na Corte, já os que "se achavam à venda" incluíam-se os importados da metrópole. SILVA, Maria Beatriz Nizza da. "Livro e sociedade no Rio de Janeiro". Separata da Revista de História No 94. São Paulo - Brasil. 1973. p. 443. 
realizarem múltiplas leituras acerca da realidade vivida. ${ }^{125}$ Segundo o historiador Marco Morel, a difusão das palavras independentemente de sua natureza - falada, manuscrita ou impressa ultrapassava as fronteiras sociais e perpassava amplos setores da sociedade não ficando estanque ao restrito círculo de letrados. Apesar disso, eram estes homens de letras que detinham o poder de produção e leitura direta da palavra impressa, com destaque para a imprensa. ${ }^{126}$

Este foi o caso do físico-mor Manoel Vieira da Silva. Personalidade de grande prestígio na Corte, o ilustre súdito publicou, a pedido do Príncipe Regente, a obra Reflexões sobre alguns dos meios propostos por mais conducentes para a melhoria do clima da cidade do Rio de Janeiro. As moléstias da cidade preocupavam D. João, que pedia urgência na escrita da obra para, assim, resolver os problemas da saúde pública. ${ }^{127} \mathrm{O}$ pragmatismo da ordem monárquica teria resposta ainda em 1808, quando o livro foi impresso pela Tipografia Real sendo, portanto, uma das primeiras publicações veiculadas pela Impressão Régia. ${ }^{128}$ No Prólogo, Vieira da Silva justificava a rápida impressão. “[D. João] Ordenou o seu Físico-mor que dissesse por escrito o que pensava sobre esta matéria, para assim excitar as pessoas instruídas a fazerem públicos os seus sentimentos, e apurar-se pela discussão um artigo, que

\footnotetext{
125 Para uma análise sobre a multiplicidade desse universo impresso, ver SILVA, Maria Beatriz Nizza da. "A imprensa periódica na época joanina". In: NEVES, Lúcia Maria Bastos Pereira das. Livros e Impressos: retratos do Setecentos e do Oitocentos. Rio de Janeiro: EdUERJ, 2009. p. 15-30; MOREL, Marco. “Das gazetas tradicionais aos jornais de opinião: metamorfoses da imprensa periódica no Brasil". In: NEVES, Lúcia Maria Bastos Pereira das. Livros e Impressos: retratos do Setecentos e do Oitocentos. Rio de Janeiro: EdUERJ, 2009. p. 153-184; MEIRELLES, Juliana Gesuelli. Imprensa... Op. Cit.

${ }^{126}$ MOREL, Marco. “Das gazetas..., Op. Cit., p. 163.

127 SILVA, Manoel Vieira da. Reflexões sobre... Op. Cit.

128 GRJ. 1808. No14. (Edição de 29/10/1808).
} 
todo se dirige para bem dos Povos". ${ }^{129}$ Ainda no Prólogo, Silva convidava "os mais sábios e inteligentes para dizerem coisas melhores"; o que propiciaria tanto a execução das "boas sugestões" pelo governo quanto à satisfação do público que tiraria "as vantagens que tanto são para desejar". ${ }^{130}$

Para além de propor a reorganização da saúde pública da nova capital, cujo tema, segundo ele, "em todos os tempos tem merecido as primeiras atenções dos grandes legisladores"131, Manoel Vieira da Silva impulsionava uma discussão que se pretendia coletiva; até porque os problemas do Rio de Janeiro perpassavam a vida de todos os seus habitantes, cujo número aumentava significativamente desde que a urbe se tornara a residência da Coroa portuguesa. ${ }^{132}$ Ademais, com a circulação da Gazeta do Rio de Janeiro, a partir de setembro de 1808, notamos o interesse dos leitores na publicação de anúncios. ${ }^{133}$ Dentre as vastíssimas temáticas que englobaram a Seção de Avisos ao longo dos treze anos em que a realeza residiu no Brasil (1808-1821), destacamos o universo impresso e o empenho desses sujeitos na veiculação de seus projetos literários.

\footnotetext{
129 SILVA, Manoel Vieira da. Reflexões sobre alguns... Op. Cit., p. iii (Grifos Nossos). ${ }^{130}$ Ibid. (Grifos Nossos). cipe regente D. João mudaria radicalmente o universo sociocultural da capital da Colônia. A começar pelo crescente número de habitantes entre os anos de 1808 e 1821. Se até 1808 o Rio de Janeiro era uma cidade com cerca de 60.000 habitantes, o censo de 1821 já apontava para uma população em torno de 79.321 pessoas, contando o alto número de estrangeiros que fixaram residência, escravos, libertos e a população livre. Para uma análise historiográfica sobre o crescimento da população no período, ver ALGRANTI, Leila Mezan. O feitor ausente. Estudo sobre a escravidão urbana no Rio de Janeiro (1808-1821). Petrópolis: Ed. Vozes, 1988. p. 30.

${ }^{133}$ Para a compreensão do interesse da sociedade joanina na veiculação de anúncios na Gazeta, ver: MEIRELLES, Juliana. Imprensa e poder... Op. Cit., p. 155-180; e SILVA, Maria Beatriz Nizza da. Gazeta do Rio de Janeiro:... Op. Cit.
} 
Em 1815, por exemplo, a Gazeta anunciava mais um título produzido pela Tipografia Real: Corografia Brasílica, do clérigo Manuel Aires do Casal. ${ }^{134}$ Segundo o anúncio, a obra achava-se pronta para a impressão e aqueles que quisessem subscrevê-la deveriam depositar $1 \$ 600$ réis por cada exemplar, na loja de Manuel Mandillo. ${ }^{135}$ Segundo a lista que acompanhava a edição, houve um total de 93 subscritores, com 133 exemplares subscritos. ${ }^{136}$ Em abril de 1816 o livro não tinha saído do prelo, pois Luís Joaquim dos Santos Marrocos informava ao pai que estava realizando a sua revisão ${ }^{137}$; ainda em maio do mesmo ano, o livro se encontrava em fase de produção. A demora na impressão foi motivo de grande desconforto para o prefeito da Real Biblioteca, o Padre Joaquim Dâmaso, que escrevia à Silvestre Pinheiro Ferreira $^{138}$, pedindo as devidas explicações à Junta da direção da Tipografia Régia.

Desde novembro se trabalha na obra do P. Aires de Casal; semanas tem havido em que tem saído 4 folhas, e em outras cinco, e apesar disto tem saído 25 folhas só, tantas tem sido as Semanas: Que razão terá havido para não serem todas as semanas iguais? Será por não se pagar quando querem, e adiantado? Será por falta de papel? Nenhuma destas faltas tem havido. Será por se demorarem as provas? Também não; porque se vem pela manhã, vão à

${ }^{134}$ Sobre a figura de Aires de Casal e a importância de sua obra para a História do Brasil, ver: GUIMARÃES, Lúcia Paschoal. "Manoel Aires do Casal" In: NEVES, Lúcia Bastos Pereira das; VAINFAS, Ronaldo. Dicionário do Brasil Joanino... Op. Cit., p. 316-317.

135 GRJ. 1815. n. 59.

136 SILVA, Maria Beatriz Nizza da. "Livro e sociedade no Rio de Janeiro"... Op. Cit., p. 446.

${ }_{137}$ MARROCOS, Luís Joaquim dos Santos. Cartas do Rio de Janeiro... Op. Cit., p. 333. [Carta 98].

${ }^{138}$ Silvestre Pinheiro Ferreira era um dos diretores da Impressão Régia e da Gazeta do Rio de Janeiro. 
tarde, se vem de tarde, vão pela manhã, e muito o mesmo autor se vê na Tipografia: se os dois CC. [sic] tem sido demorada, porque o Autor desesperado com o desprezo que na Tipografia fazem a sua obra e da sua Pessoa, intentava abrir mão dela inteiramente; e quem tem a culpa?

\section{O clérigo ainda exaltava o bom comportamento de Aires de Casal:}

A civilidade com que o Autor trata a todos, não merecia que uma Oficina, e Oficina Régia, se tratem as pessoas de similhante [sic] forma, e isto em uma Oficina que necessita acreditar-se. Em todas as Oficinas, nenhuma Obra deve ser preferida à já começada, e muito mais sendo esta útil; e portanto, por experiência temos observado que sem fadiga se pode dar 4 folhas a cada semana, e se a Junta não quer que a Oficina as dê, então o autor quer se lhe entregue o Original, e pagar o que resta a dever do que se lhe entregar. ${ }^{139}$

Mesmo muito extensa, a carta do bibliotecário nos esclarece alguns aspectos importantes dos bastidores da Impressão Régia. É patente o conflito de interesses entre os diretores da Tipografia Régia e o autor da obra. Muito provavelmente, as obras a serem produzidas sem custos eram escolhidas, em última instância, pelo Príncipe Regente, o que podia causar desconforto aos dirigentes da Impressão Régia. Se estes não ousavam questionar as preferências literárias do monarca, acabavam por realizar o projeto selecionado dentro dos prazos que eles próprios estabeleciam, ou seja, sem data limite para a conclusão. Na ocorrência de Casal - através da irregularidade na entrega do material aos

139 Joaquim Dâmaso. Real Biblioteca, 01 de maio de 1816. Apud CAMARGO, Ana Maria de Almeida; MORAES; Rubens Borba de. Bibliografia... Op. Cit., Vol. 1.p. 182. 
editores do projeto (que se incluem aí os funcionários da Biblioteca, entre eles Luís Marrocos), os diretores optaram por dar morosidade à produção do livro e desprezar as súplicas do seu autor.

A intervenção de Padre Dâmaso também pode ser lida como um alerta aos chefes da Tipografia Real: se a Coroa prezava pela consolidação de uma instituição tão vinculada a um projeto específico de Império - que perpassava educar politicamente seus súditos através da produção de obras pedagógicas, da arte à ciência -, era inadmissível uma atitude tão desrespeitosa por parte de seus diretores. Em outras palavras, o Padre advertia-os: como súditos responsáveis pela estruturação e funcionamento dessa instituição, eles deveriam reverenciar, acima de outros interesses, o status quo.

Ao final da carta, apesar de Dâmaso justificar sua "impertinência" através da "Justiça da Causa"140, notemos que este se dirigiu aos seus colegas diretores em pé de igualdade, demonstrando a autoridade do seu lugar de Prefeito da Real Biblioteca. Em tempos de institucionalização da palavra impressa no Rio de Janeiro - em que pese o nascimento de novos livros e de sua circulação e leitura pela cidade e, quiçá, pelos dos dois lados do Atlântico -, a figura do bibliotecário parecia ser imprescindível. E sua intervenção, indiscutível. Tanto é, que enfim, depois de tantos desentendimentos, em 1817, a obra "saía à luz". Deste episódio ainda podemos entrever o quanto o trabalho dos funcionários da Real Biblioteca e da Impressão Régia eram interdependentes, mormente quando se tratava de preservar a instrução.

Ainda em 1815, Roberto Ferreira da Silva anunciava que pretendia "dar ao prelo uma coleção de perspectivas dos mais interessantes pontos desta corte e seus subúrbios". Para o sucesso do

140 Joaquim Dâmaso. Real Biblioteca, 01 de maio de 1816. 
empreendimento, no entanto, o autor também rogava ao público que subscrevesse a sua obra. Os interessados podiam dirigir-se à loja de José Antônio Pinheiro Filho, na Rua Direita, onde pagariam pela subscrição. ${ }^{141}$ Como nos informa Maria Beatriz Nizza da Silva, o alto custo da obra impossibilitou a impressão. Dois anos depois, contudo, Ferreira da Silva realizava o seu projeto literário. Com um orçamento mais barato, em 1817 publicava pela Impressão Régia a obra Elementos de Pintura e Regras Gerais da Perspectiva, que contou com 172 subscritores, entre eles nomes da nobreza portuguesa e dos negociantes fluminenses. ${ }^{142}$

Enquanto algumas obras saíam do prelo, outras ficavam apenas no projeto. Ainda de acordo com Nizza da Silva, estas duas situações ocorriam por razões distintas. Quando a Impressão Régia editava as obras "por ordem de S.A.R”, os custos da impressão saíam do Real Erário, não gerando despesas financeiras para os autores. Por outro lado, a Tipografia Real também aceitava publicar textos de escritores desconhecidos. Estes originais, além de serem submetidos à censura, precisavam recorrer ao tradicional sistema de subscrição para virem à luz, dado o alto valor da impressão. ${ }^{143}$ Em maio de 1817, por exemplo, Marrocos avisava a seu pai sobre a subscrição da obra Retratos e elogios dos varões e donas que ilustraram a nação portuguesa, anunciada na Gazeta do Rio de Janeiro e cujo exemplar fora enviado juntamente com a carta. ${ }^{144}$

141 GRJ. 1815, No 20.

${ }^{142}$ SILVA, Maria Beatriz Nizza da. Gazeta do Rio de Janeiro (1808-1822)... Op. Cit., p. 181.

${ }^{143}$ Ibid., p. 179-180.

144 A subscrição ainda podia ser feita na Loja de Saturnino, na rua da Alfândega, Manoel Mandillo, na rua Direita, e Manoel da Silva Porto, na rua da Quitanda. GRJ. 1817. № 37. 
[...] tenho na Livraria uma folha de Subscrição, de que me fez favor encarregar-se o Padre Joaquim Dâmaso, e na qual por suas diligências já se assinaram mais de 16 pessoas, assim literatas, como da primeira grandeza, que ali concorrem; e se espera aumentar este número consideravelmente, porque não só uns servem de estímulo aos outros, mas tem à vista o exemplar que daí [Lisboa] se me remeteu, e que sem o desfrutar tenho-o ali para este fim depositado. ${ }^{145}$

Como já analisamos anteriormente, as subscrições de uma obra não apenas davam visibilidade pública ao subscritor, como também era um caminho possível para o alcance de futuras mercês; afinal de contas, como bem demonstrou Marrocos, se em uma sociedade de corte a hierarquia ditava os lugares sociais, a subscrição de uma obra aparecia como um privilégio para poucos. Como bem analisou Tania Ferreira, nesse período, "a expressão de opinião e a manifestação estética não eram compreendidas, tal como ocorre hoje, como direitos". ${ }^{146}$ Para além dos múltiplos sentidos e dificuldades vigentes neste mundo, a produção editorial da primeira tipografia brasileira era ampla, diversificada e muitos de seus livros tinham grande valor cultural. Entre 1808 e 1822, foram impressos 720 títulos de naturezas diversas: opúsculos, sermões, prospectos, obras literárias e científicas sobre matemática, história, ciência política, econômica e filosofia, teatro, romances, dramas, entre outros, constituíram os gêneros literários mais populares no período. ${ }^{147}$

145 MARROCOS, Luís Joaquim dos Santos. Cartas do Rio de Janeiro (18111821)... Op. Cit., p. 355. [Carta 105].

146 FERREIRA, TANIA Maria Tavares Bessone. "Redatores, livros, e leitores em O Patriota". In: KURY, Lorelai. (Org.) Iluminismo e Império no Brasil: O Patriota (1813-1814). Rio de Janeiro: Editora Fiocruz, 2007. p. 53.

147 CAMARGO, Ana Maria; MORAES, Rubens Borba de. Bibliografia da Impressão... Op. Cit., p. 229. 
Os constantes anúncios de venda de livros, folhetos e impressos no Rio de Janeiro, cotidianamente veiculados na Gazeta, indicam-nos que o estabelecimento da tipografia foi de grande importância para o enraizamento da prática da leitura na sociedade joanina. Além disso, as numerosas listas de livros à espera de liberação da censura na alfândega da cidade, como demonstrou Leila Mezan Algranti, colocavam o Rio de Janeiro em um novo estágio da cultura literária: para além de produtor de novos títulos, e provavelmente centro distribuidor de obras impressas para as demais capitanias, a nova capital também atraiu livreiros responsáveis pelo comércio legal de livros, assim como os que se envolviam com o tráfico ilícito de obras. ${ }^{148}$

Os possíveis gostos e preferências do público leitor/consumidor da época também podem ser apreendidos pelos numerosos avisos literários veiculados na Gazeta que, em sua grande maioria, conservava a tradição literária herdada do século XVIII: belas letras, teologia, ciências e arte, história e jurisprudência. ${ }^{149}$ A publicação da nova edição em prosa de Carta de Heloísa a Abelardo, vendida nas lojas de Manoel Joaquim da Silva Porto, e na Loja da Gazeta, por 320 réis ou a tradução da obra de Edmund Burke pelo Visconde de Cairu, entre os ilustrados da Corte, são importantes exemplos dessa tradição. ${ }^{150}$

\footnotetext{
148 ALGRANTI, Leila Mezan, Livros de Devoção... Op. Cit., p. 161.

149 Para maiores informações sobre a quantidade de anúncios de obras literárias e impressos publicados na Gazeta do Rio de Janeiro entre 1808 e 1822, ver NEVES, Lúcia Ma . Bastos P. das. "Comércio de livros e censura de idéias: a atividade dos livreiros franceses no Brasil e a vigilância da Mesa do Desembargo do Paço (1795-1822)”. In: Ler História, 23, p. 62, 1992.

${ }^{150}$ Para a obra Carta de Heloísa a Aberlado, ver GRJ. 1812. N 97. Já para o impacto da tradução de feita por José da Silva Lisboa (Visconde de Cairu), ver KIRSCHNER, Tereza Cristina. "D. Rodrigo de Souza Coutinho e os ilustrados na Corte de D. João”. In: MARTINS, Ismênia; MOTTA, Márcia. 1808: a corte no Brasil. Rio de Janeiro: Editora da UFF, 2010. p. 228.
} 
No Brasil do início do Oitocentos, a prática da leitura passava por um significativo processo de transição. Inscritos na lógica vigente do Antigo Regime, os primeiros anos de estadia da Coroa portuguesa foram marcados pelo predomínio de uma leitura cujas características privilegiavam a oralidade e a leitura coletiva feita em voz alta. "A leitura ouvida não distingue o ler do contar e alimenta-se dos mesmos textos escutados muitas vezes - o que é a própria condição de sua compreensão possível, a despeito da leitura pouco inteligível que aí é feita", afirma Roger Chartier. ${ }^{151} \mathrm{Na}$ prática, ainda eram comum os pregões, os bandos, as exposições de cartazes impressos ou manuscritos nas ruas, que expandiam o ato de ler para além dos limites impostos pela alfabetização. Por essa perspectiva, os editais afixados na cidade tinham esse propósito: veicular de forma ampla as decisões e notícias governamentais. Em 24 de Junho de 1808, por exemplo, o Intendente da Polícia afixou o Edital que decretava que competia à junta administrativa vigente "examinar os papéis e livros que se mandassem publicar e fiscalizar para que nada se imprimisse contra a religião, a moral e os bons costumes." Em uma ação complementar à dos administradores da tipografia, o intendente da polícia também tinha licença para prender aqueles que transgredissem a "segurança pública", sob pena de multa de duzentos mil réis. Transgredir significava veicular publicações consideradas sediciosas como "obras, escritos estrangeiros, impressos, ou não impressos" ou mesmo fazer circular manuscritos pela cidade com ideias contrárias ao governo. Todos viviam sob a constante atenção da polícia, que admitia e incentivava denúncias em segredo. ${ }^{152}$ Essa atitude

151 CHARTIER, Roger. (Org). "Do livro à leitura..., Op. Cit., p. 84.

${ }^{152}$ Instrução de 24 de junho de 1808. Apud RIZZINI, Carlos. O livro, o jornal e a tipografia no Brasil. Rio de Janeiro: Livraria Kosmos Editora, 1946. p. 317. 
sofreu uma crítica feroz de Hipólito da Costa, redator do Correio Braziliense, que, ao publicar o edital no jornal (com data de 30 de maio de 1809), refletia sobre suas "incoerências legais":

[...] há umas que se fazem mui conspícuas: uma o erige em intendente da Polícia em legislador, arbitrando multas de sua própria autoridade; outra admitir, contra os princípios da justiça universal, as denúncias ocultas [...] porque em fim nenhum jurisconsulto, criminalista, hoje em dia, deixa de reconhecer as acusações particulares. ${ }^{153}$

A crítica do jornalista traz a tona uma questão muito relevante para a leitura no período joanino: a proibição da escrita, circulação e publicação de obras manuscritas e impressas cerceava a liberdade de pensamento ao mesmo tempo em que estabelecia a autoridade autorizada da escrita como "um instrumento de poder que aproxima o autor do poder real". ${ }^{154}$ Em 1809, a notícia na Gazeta do Rio de Janeiro sobre a apreensão de uma Gazeta manuscrita na Corte, contendo blasfêmias contra Beresford, afirmava que "a vulgarização destas falsas notícias tem por particular objeto semear a desunião, e desconfiança entre este Governo, e o de S. M. Britânica", razão pela qual o redator sentiu-se autorizado "a desmentir completamente tudo o que contém aquele infame papel contra cujos faltores [sic], ou contra os que procuram vulgarizá-lo, mandará certamente S.A.R proceder com toda a severidade das leis". ${ }^{155}$

Por outro lado, esse mesmo cenário impulsionava os estudos e a formação filosófica dos súditos luso-brasileiros. Este é o caso de Silvestre Pinheiro Ferreira, um dos conselheiros de

${ }^{153}$ CB. Vol. III, p. 341.

154 SCHIAVINATTO, Iara Lis Franco. “Entre os manuscritos..., Op. Cit., p. 19.

155 GRJ. 1809. N ${ }^{\circ} 127$. 
D. João no Brasil. Além de ministro régio, Ferreira era um homem de vasta cultura. Político, diplomata e filósofo, sua atuação intelectual foi de muita relevância para o avanço do conhecimento na Corte. Com a obra Preleções Philosophicas, publicada pela Impressão Régia entre os anos de 1813 e 1820, Ferreira difundia e exaltava o valor dado à retórica. De acordo com José Murilo de Carvalho a visão de Pinheiro Ferreira se parecia com a de Verney. "Para o autor das Preleções, a retórica não deveria separar-se da lógica e da gramática [...] Isto é, a arte de pensar não se devia separar da arte de falar com clareza, a retórica não devia ser enfeite mas instrumento cotidiano de argumentação e persuasão". ${ }^{156}$

Tal foi a valorização das suas Preleções pelo governo joanino que a Gazeta do Rio de Janeiro e O Investigador Portuguez em Inglaterra anunciavam a novidade. Enquanto o primeiro periódico avisava os moradores da Corte sobre o horário e local onde aconteciam as aulas ${ }^{157}$, o segundo divulgava, do outro lado do Atlântico, as principais ideias do autor. Em missiva ao pai, em maio de 1813, Marrocos contextualizava o momento: "Silvestre Pinheiro está metido a Projetista, e as suas lições reduzem-se a uma mescla científica que se não sabe o que é: estamos no tempo das Gramaticas Filosóficas, e o Sistema de todas as Línguas reduzido a uma só praxe". ${ }^{158} \mathrm{Na}$ edição de outubro de 1814,

\footnotetext{
156 CARVALHO, José Murilo de. "História intelectual no Brasil: a retórica como chave de leitura". TOPOI. Rio de Janeiro, no 1, p. 133-134. Ver também SILVA, Maria Beatriz Nizza da. Silvestre Pinheiro Ferreira: ideologia e teoria, Lisboa: Sá da Costa, 1975.

157 Segundo o aviso da Gazeta, as aulas aconteciam as segundas, quartas e sextas-feiras, às 17 hs, no Colégio de $\mathrm{S}$. Joaquim. O jornal ainda noticiava o conteúdo teórico das aulas, assim como as atividades práticas, que englobavam "a lição e análise de alguma obra escolhida dos principais Filósofos, Oradores e Poetas, assim antigos, como modernos, sagrados e profanos." GRJ. 1813. № 30.

158 MARROCOS, Luís Joaquim dos Santos. Cartas do Rio de Janeiro... Op. Cit., p. 185. [Carta 43A].
} 
O Investigador informava os seus leitores acerca do recebimento da obra ${ }^{159}$; já no número seguinte, abria um amplo espaço para os interlocutores conhecê-la.

De uma obra desta natureza é impossível fazer bons extractos, e até dignos do seu mui relevante merecimento. Parece-nos pois que a melhor ideia que por ora podíamos dar era publicar uma espécie de Índice dos pontos importantes de que trata. Se tivermos porém ocasião, publicaremos tão bem ainda por inteiro as ditas Prelecções, para que a sua leitura mais se generalize, e assim prepare todas as utilidades que pode e deve produzir um tal género de instrução Elementar. ${ }^{160}$

Logo após o comentário dos redatores, a folha publicava a Ideia Geral da Obra, destacando os principais pontos acerca da Física e da Dinâmica. Diferentemente ds comentários elogiosos d'O Investigador, Luís Joaquim dos Santos Marrocos era um crítico contumaz do autor. "Não sei, se será erro meu em dizer que Silvestre Pinheiro é daqueles homens, que tem habilidade em infundir veneração científica; e inculcando-se Corifeu enciclopédico, granjeia um partido, que ouvem suas palavras soltas, como vozes de Oráculo", observava o bibliotecário. ${ }^{161}$ Quanto à repercussão e importância da obra, o exame desse seleto homem de letras foi ainda mais ácido.

O Padre Joaquim Dâmaso [...] nos inculca[-o] sempre por superior a todos, nos tempos actuais, em luzes e conhecimetos; e eu, ao contrário, vejo nas suas Prelecções impressas Definições e Teoremas, que por sua ostentação

159 IP. Vol. X, p. 627.

${ }^{160}$ Ibid., Vol. XI, p. 53.

161 MARROCOS, Luís Joaquim dos Santos. Cartas do Rio de Janeiro Op. Cit., p. 327. [Carta 96]. 
de novidade só me causam riso, ou nojo; apesar da ilustrada Análise, qu lhes fazem os Redactores do Investigador Português, elevando-as às nuvens. ${ }^{162}$

Nesta carta ao pai, Luís Marrocos demonstrava a insatisfação com a atiude de seu superior, o Padre Dâmaso, assim como reiterava a sua leitura crítica sobre as funções "filosóficas" que, por ventura, a obra intentava atingir. Ainda como leitor assíduo d'O Investigador, fazia uma análise acerca da publicidade que o jornal dava à obra. Por mais que respeitasse o trabalho de seus redatores, achava-o um tanto exagerado. Todas essas transformações do mundo público, associadas à leitura perspicaz de Marrocos, nos ajudam a melhor compreender os caminhos trilhados pelos manuscritos e impressos no Rio de Janeiro, no raiar do século XIX. Segundo a historiadora Iara Lis Schiavinatto "Aos poucos, o manuscrito deixaria de gozar do mesmo prestígio, crédito e capacidade de afirmar a verdade que o impresso", passando a se aproximar "do rumor, da murmuração, do ouvir-dizer". ${ }^{163}$ Com o predomínio das publicações impressas na Corte, portanto, vemos o nascimento e constituição de um novo espaço público cujo centro será a imprensa, compreendida como uma arena de debates. ${ }^{164}$ Há a emergência das leituras individuais e privadas perceptíveis mais nitidamente a partir de 1821 , onde a pluralidade de periódicos e o debate sobre as questões políticas permitiram, segundo Marco Morel, "a formação de uma opinião de caráter mais abstrato, fundada sobre o julgamento crítico de cada cidadão-leitor e representando uma espécie de somatório das opiniões". ${ }^{165}$

\footnotetext{
162 Ibid.

163 SCHIAVINATTO, Iara Lis. "Entre os manuscritos e os impressos..., Op. Cit., p. 14.

164 MEIRELLES, Juliana Gesuelli. Imprensa e poder... Op. Cit., p. 165.

165 MOREL, Marco. As transformações... Op. Cit., p. 205. Para as características da leitura no Antigo Regime na França ver ROCHE, Daniel. O povo de Paris... Op. Cit., cap. 7, p. 267-309.
} 
É dentro desse universo da cultura letrada - em que a posse, leitura e circulação de livros ganhavam cada vez mais proeminência na Corte -, que ocorreu o processo de transladação da Real Biblioteca para este lado do Atlântico. Do nascimento da Impressão Régia (1808) à abertura da Real Biblioteca do Rio de Janeiro (1814), o acesso à leitura sofreu uma guinada. Nesse período, houve uma crescente variedade de gêneros e títulos, inclusive com um aumento significativo do interesse dos leitores pelas ideias dos filósofos iluministas, como Voltaire, Rousseau e Montesquieu. Apesar da curiosidade, as obras mais famosas eram consideradas "sediciosas" pelos censores de D. João, que vedavam constantemente a sua circulação. "O Sistema da Natureza, de Holbach, best seller entre as obras proibidas na França nessa época, parece também ter sido desejado pelos leitores da Colônia, pois os livreiros estrangeiros e portugueses tentavam introduzi-lo com frequência no país", afirma Leila Algranti. ${ }^{166}$

Se, por um lado, os censores dedicavam especial atenção para a entrada dos livros proibidos, a exemplo das obras francesas, com destaque para Émile, de Rousseau, Historie philosophique, do abade Raynal e Os direitos do Cidadão, de Mably, por outro, também escolhiam e incentivavam a produção de livros muito procurados ou populares à época, como os 23 volumes de A sagrada Bíblia traduzida em português pelo padre Antonio Pereira, ao preço de 28 mil réis, e o Índice da $1^{a}$ parte da já citada Preleções Filosóficas, dispostas em ordem alfabética; ambos vendidos na loja de livros de Francisco Luís Saturnino. ${ }^{167}$ Além disso, podiam ser facilmente comprados em outras casas livreiras da cidade. Em 1817, os interessados em livros de jurisprudência

166 ALGRANTI, Leila Mezan. Livros de devoção, atos de censura... Op. Cit., p. 149 167 GRJ. 1818. Nº5. 
tiveram a oportunidade de arrematá-los em leilão. Para o evento, José Balbino Barbosa de Araújo, oficial da Secretaria de Estado dos Negócios do Brasil, anunciava obras portuguesas, francesas e inglesas sobre o tema, além de outros folhetos. ${ }^{168}$ Especificamente em relação à formação da Biblioteca Real do Rio de Janeiro, a antropóloga Lilia Schwarcz nos informa que nos transtornos do embarque, em novembro de 1807, a primeira remessa de livros ficou abandonada no porto de Belém até que alguns dias depois retornou ao Palácio d'Ajuda. ${ }^{169}$ Apesar disso, o transporte das obras e coleções foi tratado como questão prioritária de Estado, sendo, ao todo 60 mil peças, entre "obras raras, livros de educação, tratados, costumes, geografia ou ciências; documentos da Coroa, manuscritos, incunábulos, livros de oras e demais obras de oração, assim como desenho, mapas e gravuras" que foram cuidadosamente colocados em 317 caixotes com a devida classificação. ${ }^{170}$

$\mathrm{O}$ acervo foi acomodado em uma das salas do Hospital do Convento da Ordem Terceira do Carmo, na Rua Direita. Segundo Padre Perereca, o hospital foi escolhido "não só por causa da vizinhança do Paço, mas também pela capacidade deste edifício o melhor que se podia encontrar para este fim". Ainda de acordo com o clérigo, com a acomodação do acervo neste local, o hospital foi transferido para o recolhimento de Nossa Senhora do Parto que, por sua vez, transferiu as meninas que ali viviam para o recolhimento da Santa Casa da Misericórdia. ${ }^{171}$

A proteção e conservação das bibliotecas reais foram temas constantemente discutidos nas correspondências diplomáticas.

\footnotetext{
168 Ibid., $\mathrm{N}^{\circ} 38$.

169 SCHWARCZ, Lilia M. A longa... Op. Cit., p. 262.

170 SCHWARCZ, Lilia. "Biblioteca Real”. In: NEVES, Lúcia Bastos Pereira das; VAINFAS, Ronaldo. Dicionário do Brasil Joanino... Op. Cit., p. 61.

171 SANTOS, Luiz Gonçalves dos. Memórias para servir... Op. Cit., p. 425.
} 
Em 12 de outubro de 1808, Antonio Alexandre das Neves ${ }^{172}$, bibliotecário da Real Biblioteca d'Ajuda, vangloriava-se de ter salvado os papéis públicos e caixotes de livros das quatro tentativas do governo francês de dilapidação do patrimônio nacional. Segundo o súdito, o sucesso de tal preservação, no entanto, devia-se mais à ação da Providência Divina, que fizera com que os invasores se esquecessem de pegar as chaves do estabelecimento. ${ }^{173}$ Ainda em janeiro de 1809, o mesmo funcionário mencionava o envio de mais caixotes para a América Portuguesa.

Para não aumentar o susto que se vai espalhando por Lisboa, vendo-se os preparos dos Negociantes Ingleses para saírem; e considerando-se em que tais acontecimentos não deixam de proceder de reflexões mui[to] sérias: trato com os meus companheiros de encaixotar mui[to] ocultamente os Papéis particulares, e Manuscritos, e os mais livros os que couberem nos caixões que existem dentro das mesmas bibliotecas. Porém são precisos muitos outros caixões, e algum socorro aos Empregados. ${ }^{174}$

Neves referia-se à eminência de uma nova invasão francesa, que acabou por acontecer em março do dito ano. A mensagem estava dada: a Coroa não podia mais contar com a sorte, sendo absolutamente necessário fazer o envio das "preciosidades" do Estado Português para o Brasil. Ainda em janeiro, o governo português mandou um Aviso para Antonio Ribeiro dos Santos alusivo aos livros reais:

\footnotetext{
172 De acordo com Ana Cristina Araújo, Antonio Alexandre das Neves era sócio e guarda-mor dos estabelecimentos literários da Academia Real das Ciências e diretor da Junta da direção literária da Imprensa Régia e Real Biblioteca da Ajuda. ARAÚJO, Ana Cristina. "Uma longa despedida: Cartas familiares de Luís Joaquim dos Santos Marrocos". In: MARROCOS, Luís Joaquim dos Santos. Cartas do Rio de Janeiro... Op. Cit., p. 20.
}

${ }_{173}$ ANTT. Ministério do Reino. Mç. 279. Caixa. 372.

${ }^{174}$ Ibid. 
O Príncipe regente Nosso Senhor é servido, que V.S. ${ }^{a}$ mande encaixotar sem perda de tempo o monetário da livraria Pública ${ }^{175}$, e mais preciosidades da mesma, para se provem em segurança nas embarcações da Coroa; apresentando relação do número dos caixotes com as dimensões de cada um deles, logo que se perder [sic] calcular o mesmo número, ao secretário do governo encarregado do Real Erário, para determinar o navio, em que se embarcaram imediatamente. ${ }^{176}$

Desde a instalação da Corte no Brasil, em 1808, que a necessidade da Coroa em preservar o seu patrimônio literário se colocava como uma de suas mais destacadas preocupações. Sendo a livraria um "espaço emblemático da Corte", na expressão de Ana Cristina Araújo ${ }^{177}$ (o que na prática lhe concedia grande respeitabilidade como signo da monarquia e da nobreza), era imprescindível que a realeza constituísse esse locus de saber na nova sede de sua residência. Só que para isso, o governo português precisava transladar seguramente um dos seus bens mais preciosos: a coleção de livros e manuscritos raros. Diante de um empreendimento de tal monta a escolha dos profissionais não poderia ser mais

\footnotetext{
175 "É sabido que os bibliotecários e arcebispos deixaram algumas obras para a biblioteca pública. Os fundos iniciais foram constituídos com os generosos donativos do Fundador, que terá deixado de acordo com as suas palavras, para cima de 40.000 volumes mais um monetário com 2995 espécimes de ouro, prata e cobre e que depois foi roubado pelos franceses em 1808." A análise do pesquisador Francisco António Lourenço Vaz sobre a Biblioteca Pública de Évora no período joanino nos indica que, possivelmente, o monetário correspondia a doações para a Biblioteca em metais preciosos. VAZ. Francisco António Lourenço. "Os bibliófilos eborenses e a Biblioteca Pública de Évora (18051955)”. Disponível em; <http://www.projectos.uevora.pt/cenaculo/pub_pdf/ VAZ4_2007_BibliofilosEborenses.pdf>. Acesso em: 01 dez. 2012.

176 Aviso em que manda encaixotar o monetário, e mais preciosidades. BNP. Seção de Reservados. Cód.10612 (Grifo nosso).

177 ARAÚJO, Ana Cristina. “Uma longa despedida:..., Op. Cit., p. 25.
} 
coerente: tamanha incumbência ficava nas mãos de dois diletos homens de letras da corte lusitana, os bibliotecários régios, que conheciam em detalhes os acervos de suas respectivas instituições: a Real Biblioteca d'Ajuda e a Real Biblioteca Pública de Lisboa. Ambos, portanto, sabiam catalogá-lo da forma mais adequada à organização de sua congênere no Brasil. Aqui reiteramos o fato de uma biblioteca ser um dos maiores símbolos de status na Idade Moderna, sendo a posse de livros e/ou a alfabetização duas qualidades distintivas na sociedade de Corte. ${ }^{178}$

Neste cenário nos interessa discutir as transformações que vigoraram na cidade, mormente em relação ao mundo dos livros, em particular, e da circulação da palavra impressa, em geral. Sobre a transferência da residência real para a América e o processo de estruturação do aparato governamental, Ana Cristina Araújo é enfática:

A capitalidade política do Rio de Janeiro implicava a existência de rituais de informação e cerimônias públicas, até então distantes ou apenas imagináveis, mas que ao materializarem-se no grandioso cenário dos trópicos, contribuíam para impor uma imagem inédita e perdurável da materialidade do poder real. ${ }^{179}$

Principalmente nos primeiros anos de estadia (1808 a 1815), o governo joanino cuidou da proteção de seu patrimônio intelectual por outras vias que não apenas a estruturação, abertura e funcionamento da Real Biblioteca do Rio de Janeiro. A Impressão Régia autenticava a visibilidade ao domínio simbólico almejado pela Coroa através da circulação dos papéis oficiais, assim como das demais produções impressas que saíam dos

178 DARNTON, Robert. O grande massacre... Op. Cit., p. 284-292.

179 ARAÚJO, Ana Cristina. "Uma longa despedida:..., Op. Cit., p. 31. 
prelos reais. "[O governo] nunca se divorciou de outras exigências de leitura, encarregando-se da publicação de obras políticas, econômicas, literárias, científicas e filosóficas", afiança Araújo. ${ }^{180}$ Ademais, como já demonstramos anteriormente, os periódicos produzidos pela mesma Tipografia - a Gazeta do Rio de Janeiro (1808-1821) e O Patriota (1813-1814) - ou aqueles patrocinados pela Coroa - como foi o caso d'O Investigador Portuguez em Inglaterra (1811-1819) também foram parte fundamental da política cultural da monarquia lusitana. ${ }^{181}$

Para além da atividade impressa, a coerção aos súditos com leituras críticas à ordem estabelecida foi uma constante. No início de 1810, por exemplo, o Conde de Aguiar escrevia da Corte para o Patriarca Eleito de Lisboa sobre a prisão dos insultantes do governo. No discurso do ministro uma questão se sobressai: o processo de repressão àqueles contrários ao governo e a justificativa para as prisões. ${ }^{182}$

[Sobre a] medida que esse governo tomou de mandar prender nas fortalezas alguns indivíduos, e repreender outros, constantes da relação de n.5 por continuarem com as suas declamações, e práticas insultantes, e sediciosas; e

180 Ibid., p. 31.

181 Sobre a política cultural do governo joanino voltada exclusivamente para os periódicos de circulação interatlântica, ver o Capítulo 1 deste livro intitulado "A imprensa como locus de saber". Para a compreensão deste processo especificamente em relação à Gazeta do Rio de Janeiro, ver MEIRELLES, Juliana. G. Imprensa e poder... Op. Cit., Cap. 2, p. 91-154.

${ }_{182}$ Entre os anos de 1808 e 1812, Fernando José de Portugal e Castro, Conde de Aguiar (1752-1817) ocupou dois cargos de relevo no governo joanino: para além de atuar no Ministério dos Negócios do Reino ainda era presidente do Real Erário e ministro assistente do despacho, função equivalente à de Primeiro Ministro, segundo a historiadora Lúcia Paschoal Guimarães. Para mais informações sobre trajetória do ministro, ver: GUIMARÃES, Lúcia Paschoal. "Fernando José de Portugal e Castro.” In: NEVES, Lúcia Bastos Pereira das; VAINFAS, Ronaldo. Dicionário do Brasil Joanino... Op. Cit., p. 163-164. 
recomenda nesta matéria toda a cautela, circunspecção, e vigilância para se manter a tranquilidade pública; o que sendo sempre necessário, de muito mais em circunstâncias tão críticas ... ${ }^{183}$

Aguiar se referia à expulsão dos franceses do Reino. Em um cenário de guerra todo o cuidado era pouco. A alta vigilância da Intendência da Polícia era um imperativo e, na prática, recaia principalmente sobre os estrangeiros e os homens de imprensa, os últimos produtores das notícias que circulavam no país. ${ }^{184}$ A censura à circulação de impressos sediciosos foi indissociável das diretrizes políticas do governo de D. João. A ordem de proibição e supressão dessas folhas na Impressão Régia, a apreensão do periódico Correio Braziliense, em 1809, a referência à prisão do Conde de Egas, por causa de seus papéis escritos de Paris, para o Conde de Almada - tendo, neste caso, a polícia como agente interrogador, compôs o rico mosaico de atitudes reais diante da instabilidade política de Portugal no raiar do século XIX.

Mas as ações governamentais não paravam por aí. A preservação dos Arquivos da Coroa em Lisboa e a valorização das qualidades morais das pessoas que tomavam conta da documentação oficial, nomeadamente contra o furor dos franceses, a licença real de impressão das obras, a vigilância dos censores e a relação com a manutenção do bem comum do Estado, a atuação da Intendência da Polícia com foco para a proteção eficaz de todo o território do Brasil, assim como a ação direta do Príncipe Regente que listou todas as obras da Real Biblioteca a serem enviadas para o

183 ANTT. Ministério do Reino. Livro 380.

184 Sobre a repressão do governo português em relação aos impressos no período, ver: TENGARRINHA, José. História da imprensa... Op. Cit., p. 57-99; MEIRELLES, Juliana Gesuelli. Imprensa e poder... Op. Cit., p. 101-133. 
Brasil $^{185}$, são exemplos fundamentais da amplitude das diretrizes monárquicas que englobavam a política cultural joanina especialmente no que concerne ao universo da palavra impressa e à coibição das ideias revolucionárias em ambos os lados do Atlântico. ${ }^{186}$ Em meio a esse conturbado contexto político europeu dava-se a constituição da Real Biblioteca do Rio de Janeiro, que, aos poucos, tomava forma sui generis. É justamente sobre a formação desse locus de cultura que agora deteremos a nossa atenção.

\subsection{O governo joanino e o projeto de uma Biblioteca Pública no Rio de Janeiro}

Ao longo de 1809 a urgência no envio do acervo da Real Biblioteca Pública de Lisboa arrefeceu-se devido ao fracasso no avanço militar dos franceses. Por outro lado, acontecia o movimento oposto com a coleção de obras pertencentes à Real Biblioteca d'Ajuda, que começavam a ser transferidas em segredo para a nova Corte em princípios de 1810. De acordo com a pesquisadora Lilia Schwarcz, a primeira leva de caixotes foi acompanhada por José Joaquim de Oliveira, servente da Real Biblioteca. Este funcionário, segundo a mesma autora, "vinha trazendo também os 'estratégicos' Manuscritos da Coroa e uma coleção de 6 mil códices que se achavam em um arquivo reservado na Livraria do Paço da Necessidades, em Lisboa". ${ }^{187} \mathrm{O}$ cuidado com esse importante acervo documental carregava consigo simbolicamente a superioridade política da nação portuguesa perante os europeus. Era a história de suas grandes conquistas e vitórias que atravessava

\footnotetext{
185 ANTT. Ministério do Reino. Livro 380, p. 459-465.

${ }^{186}$ Ibid. Livro 380.

187 SCHWARCZ, Lilia M. A longa... Op. Cit., p. 266 (Grifo Nosso).
} 
o oceano. Agora do outro lado do Atlântico, sob a direção do Príncipe Regente D. João, o Império lusitano começava a reescrever e a repensar a magnitude deste novo Império, já muito fragilizado. De acordo com Maria de Lourdes Viana Lyra, a utilização do termo "novo Império" tinha duas grandes expressões políticas: para além do sentido de mudança na estruturação do império reformulado, exprimiu também a imagem de renovação da Monarquia portuguesa que, a partir de então, revigorava-se com as novas perspectivas que se abriam, mormente em relação ao domínio absoluto das imensas riquezas de suas possessões coloniais. ${ }^{188}$

Em duas viagens distintas em 1811, a Coroa portuguesa completava a travessia do rico acervo documental. A segunda leva de caixotes chegava em março, com Luís Joaquim dos Santos Marrocos. Já em setembro, este mesmo bibliotecário informava a seu pai sobre a entrada dos "últimos 87 caixotes de livros" no Rio de Janeiro, que vinham sob a responsabilidade de José Lopes Saraiva, servente da Real Biblioteca. ${ }^{189}$ Se por um lado a transladação das preciosidades reais, enfim, estava a salvo; por outro, os funcionários régios da nova instituição tinham um trabalho hercúleo pela frente.

A direção do novo espaço estava nas mãos do Padre Joaquim Dâmaso (1777-1833), pertencente à Congregação do Oratório de Lisboa, e frei Gregório José Viegas, da terceira ordem

188 LYRA, Maria de Lourdes Viana. A utopia... Op. Cit., p. 119.

189 MARROCOS, Luís Joaquim dos Santos. Cartas do Rio de Janeiro Op. Cit., p. 96 (Carta N. ${ }^{\circ}$ 10). Ao crermos na narrativa de Marrocos, seu colega de ofício José Lopes Saraiva enfrentou alguns problemas pessoais sérios em sua estadia no Brasil. Se em setembro de 1813, Marrocos relatava ao pai a pública traição de sua esposa, que o indispôs publicamente com d. Carlota Joaquina (Carta N. ${ }^{\circ} 54$, p. 222), em abril de 1814 relatava a sua prisão há mais de quatro meses por conta de uma "desordem que tivera com um Filho de certa Criada" que, segundo boatos, teria ficado "cego de um olho". (Carta N.65, p. 252). 
de São Francisco. Dâmaso supervisionou as três levas de livros que adentravam no Rio de Janeiro, entre 1810 e 1811 e, desde então, responsabilizou-se pelo arranjo e conservação do acervo da biblioteca. Com Viegas, a quem coube à administração geral do locus $^{190}$, dividiu o cargo de "Prefeito" - maior autoridade na hierarquia social da instituição. ${ }^{191}$ Eles ainda contavam com a ajuda de dois serventes - Feliciano Joaquim José de Oliveira e José Lopes Saraiva - além de Luís Joaquim dos Santos Marrocos, na função de ajudante de bibliotecário. $\mathrm{O}$ emprego de servente também tinha sido regulamentado em 1802, e entre as funções capitais destacava-se o conhecimento bibliográfico. ${ }^{192} \mathrm{De}$ acordo com Ana Cristina Araújo, "No fundo, com graduações, ordenados e funções diferentes, todos estes indivíduos eram remunerados como funcionários do Paço e nele serviam com exclusiva assistência à livraria”. ${ }^{193}$

Neste contexto, a riquíssima produção epistolar de Luís Joaquim dos Santos Marrocos ao longo de dez anos (1811 -1821), para além de compor uma excepcional documentação do período joanino, também pode ser compreendida em uma perspectiva histórica mais ampla. Ao circunscrever os significados da carta no universo setecentista português, a historiadora Adriana Angelita Conceição definiu a formação da prática epistolar "enquanto um objeto de troca de sensibilidades, sociabilidades

190 SCHWARCZ, Lilia M. "Joaquim Dâmaso" [A longa viagem da biblioteca dos reis..., p. 266]. In: NEVES, Lúcia Bastos Pereira das; VAINFAS, Ronaldo. Dicionário do Brasil Joanino... Op. Cit., p. 262.

191 As atribuições ao cargo de Prefeito foram regulamentadas no $\$$. I. do Regulamento Provisional das Reais Bibliotecas mandado observar pelo Príncipe Regente Nosso Senhor, decretado em 24/09/1802. Regulamento Provisional das Reais Bibliotecas mandado observar pelo Príncipe Regente Nosso Senhor. ANTT. Ministério do Reino. Livro 99, p. 2.

192 Ibid., p. 3.

193 ARAÚJO, Ana Cristina. “Uma longa despedida:..., Op. Cit., p. 21. 
e representações". ${ }^{194}$ Por este viés, a autora ainda reitera o fato de que a "significação das palavras não se estabelece de modo dado ou imposto, mas através dos usos e necessidades das sociabilidades partilhadas". 195

Especificamente em relação à figura de Marrocos e à produção de suas cartas, destacamos a análise de dois pesquisadores: Ana Cristina Araújo, que o considera "um protagonista oculto dos acontecimentos colectivos e um narrador comprometido, com muitas histórias para contar"196, e Emílio Lopes, para quem "As Cartas de Marrocos expressavam um 'protocolo de leitura' próprio, devido ao local em que o protagonista se situava, marcado por conflitos pessoais, lutas por ascensão social e por prestígio". ${ }^{197}$ Mesmo concordando com a análise dos dois autores, achamos necessário circunscrever a ótica particular da nossa leitura do personagem: consideramos as correspondências de Marrocos a narrativa de um súdito ilustrado de pouca visibilidade em busca de ascensão social na nova corte. A partir também deste viés, a leitura de suas missivas impõe alguns cuidados. Por mais que a sua narrativa nos permita compreender melhor as múltiplas especificidades da sociedade de corte luso-brasileira no raiar do século XIX, Marrocos lia os acontecimentos à sua volta de um lugar específico: é um português com grandes dificuldades iniciais de adaptação à vida no Rio de Janeiro; um funcionário público em busca do reconhecimento real que, para isso, procura

194 CONCEIÇÃO, Adriana Angelita da. Sentir, escrever e governar. A prática epistolar e as cartas de D. Luís de Almeida, $2^{\circ}$ Marquês de Lavradio (1768-1779). Tese de doutoramento. São Paulo: Faculdade de Filosofia e Ciências Humanas USP, 2011. p. 18.

195 Ibid., p. 67.

196 ARAÚJO, Ana Cristina. “Uma longa despedida:..., Op. Cit., p. 14.

197 LOPES, Emilio Carlos Rodrigues. Festas Publicas... Op. Cit., p. 59. 
tecer relações políticas complexas favoráveis a si no universo da alta cúpula ministerial. ${ }^{198}$

A despeito dessas circunstâncias, e acrescentando o fato de Marrocos não ter tido um cargo de alta hierarquia dentro da livraria, ou mesmo dentro de outras instituições governamentais ${ }^{199}$, é mister lembrarmos que ele desempenhou muitas atividades dentro da Real Biblioteca, o que o permitiu conhecer a estruturação e funcionamento da instituição em detalhes. Se muitas vezes suas cartas nos colocam diante de um homem ressentido, que se sentia preterido em relação a "contendores mais bem apadrinhados"200,

\footnotetext{
198 Marrocos parecia ser mais próximo a D. Rodrigo de Souza Coutinho e seus aliados. No entanto, mesmo quando o ministro era vivo, o bibliotecário solicitava ao pai que mandasse para Antonio de Azevedo de Araújo uma carta de recomendação para que ele pudesse se introduzir junto ao conselheiro real. O pai atendeu o seu pedido, enviando ao Conde da Barca uma Carta referente às qualidades do filho. Para maiores esclarecimentos, ver MARROCOS, Luís Joaquim dos Santos. Cartas do Rio de Janeiro Op. Cit., Carta No16, p. 113-114; Carta No 20, p. 127-128 e Carta No 69, p. 261.

199 Em setembro de 1817, Luís Marrocos foi nomeado oficial da Secretaria de Estado dos Negócios do Reino por Thomaz Antonio Vilanova Portugal. A partir de então, deixou de trabalhar na Biblioteca Real, mas sem perder a função. Além disso, continuou sendo o responsável pelo cuidado dos manuscritos. Em 1821, Marrocos voltava à labuta dentro da Real Biblioteca, agora, porém, no cargo de Direção e Arranjamento, em substituição ao padre Viegas, que fora nomeado bispo em Pernambuco. Sobre a sua ascensão profissional, ver MARROCOS, Luís Joaquim dos Santos. Cartas do Rio de Janeiro... Op. Cit., p. 361 [Carta N. o 106]. ${ }^{200}$ MALERBA, Jurandir. A corte no exílio:... Op. Cit., p. 217. Esta situação pode ser apreendida em inúmeras cartas do bibliotecário, porém, a carta ao pai datada de 29 de outubro de 1811, quando Marrocos chegara ao Rio há pouco mais de seis meses, já nos esclarece alguns de seus objetivos. Ao recomendar a vigilância do pai diante da aparição de "Ofício aí [Lisboa] decente e de sofrível rendimento", justifica suas razões: "Isto tudo é para ver se posso tentar fortuna, aproveitando-me das Pessoas, que me atendem e me obsequeiam; ainda que isto agora está muito esgotado, pois vejo aqui alguns Criados (e não poucos) de sua Real Alteza com 3 e 4 Ofícios de mil cruzados; mas eu não gosto de prender-me nesta terra, que julgo para mim de Degredo; e por isso me lembro do que me podes fazer conta em Lisboa, para estar seguro a todo o tempo. [...]”. MARROCOS, Luís Joaquim dos Santos. Cartas do Rio de Janeiro... Op. Cit., ver Carta N. ${ }^{\circ}$, p. 88; Carta No 171, p. 500.
} 
desejoso de voltar a Lisboa, elas também nos mostram a face de um sujeito que conheceu em profundidade o locus de saber que nos interessa investigar. Nesta pesquisa, portanto, pensamos o seu relato a partir de sua experiência particular como ajudante de bibliotecário; um súdito que por mais que almejasse sempre novas regalias e mercês, trabalhou arduamente na concretização do nascimento e vigência da Real Biblioteca do Rio de Janeiro.

Luís Joaquim dos Santos Marrocos fez a travessia atlântica em substituição a seu pai, Francisco José dos Santos Marrocos, professor régio de Filosofia Racional e Moral em Lisboa, e funcionário da Real Biblioteca d’Ajuda com muitas relações ligadas ao mundo da cultura letrada. Por mais que Luís Marrocos tenha crescido em um profícuo ambiente literário e frequentado a Universidade de Coimbra, aos 30 anos de idade ainda era um homem solteiro e dependente da família. Apesar disso, desde 1801 trabalhava sob os olhos paternos no registro de preciosas colecções régias de livros e documentos. Esta atividade lhe garantiu, dez anos depois, a experiência necessária para atravessar o oceano com a missão de levar a segunda leva de livros ao Brasil. ${ }^{201} \mathrm{Na}$ nova Corte, mais próximo à Coroa, teria maiores chances de se destacar profissionalmente.

Assim como os demais funcionários da instituição, Marrocos tinha casa paga pela Real Fazenda e um ordenado de $400 \$ 000$ réis; valor nada desprezível para a sua função. ${ }^{202}$ Passado pouco mais de três meses de sua chegada ao Rio de Janeiro, Marrocos fazia um importante pedido ao pai.

\footnotetext{
201 ARAÚJO, Ana Cristina. "Uma longa despedida:..." Op. Cit., p. 20-21.

202 Sobre a situação profissional de Marrocos ver: MARROCOS, Luís Joaquim dos Santos. Cartas do Rio de Janeiro... Op. Cit., p. 82. [Carta N. . 5, p. 82] e [Carta N. ${ }^{\circ}$ 6, p. 84].
} 
Rogo a Vossa Mercê com todo o seu empenho me mande extrair um Cópia dos Estatutos da Biblioteca de Espanha, que existe na sua mão, porque já fui insinuado a arranjar uma Obra tal, em competência da do Padre Serra ${ }^{203}$; e como não tenho, e não posso ter uma base de bom calibre para esta empresa, fiquei assombrado com a vista do raio. ${ }^{204}$

Esta súplica nos indica que os bibliotecários régios já estavam, há algum tempo, em busca do documento espanhol e, muito provavelmente, tinham pressa para finalizarem o trabalho de organização do acervo bibliográfico do novo locus de saber. Porém, para realizá-lo de modo a "favorecer, e excitar os estudo das letras divinas e humanas entre os seus vassalos no Brasil", como exaltava o Padre Perereca, necessitavam de um modelo distinto de biblioteca que não apenas a portuguesa. ${ }^{205}$ Como vemos, a escolha recaiu para a instituição espanhola, cujo esplendor deu mostras ao longo de todo o século XVIII.

Com o início dos trabalhos, que duraram quatro anos (1810-1814) até que a Real Biblioteca abrisse suas portas ao público, em 1814, houve muitas transformações. Já em outubro de 1811, um ano após o decreto que mandava erigir a Real Biblioteca na nova corte ${ }^{206}$, Marrocos informava ao pai sobre a criação de um grande "Plano de Estabelecimento Público, e Arranjamento melhor dos empregados das Reais Bibliotecas, com bons ordenados, ração, foros de criados, etc., etc.". ${ }^{207}$ Em novembro de 1811,

\footnotetext{
203 Padre Francisco José da Serra Xavier.

204 Ibid., p. 80. [Carta N.o 3].

205 SANTOS, Luiz Gonçalves dos. Memórias para servir... Op. Cit., vol. 1, p. 426.

206 O decreto real é datado de 29 de outubro de 1810. O documento pode ser lido na íntegra em <http://www.planalto.gov.br/ccivil_03/revista/Rev_69/Decreto.htm>. Acesso em: 29 out. 2012.

207 MARROCOS, Luís Joaquim dos Santos. Cartas do Rio de Janeiro Op. Cit., p. 88. [Carta N. ${ }^{\circ}$ ].
} 
pedia-lhe que "remetesse em Carta pelo Correio uma Cópia do Sistema de Classificação Bibliográfica feita pelo Doutor António Ribeiro dos Santos para a Biblioteca Pública”, ressaltando que estes "são papelinhos aqui de muita estimação, pois é terra de tudo estéril". ${ }^{208}$ Dois meses depois, em janeiro de 1812, o pai lhe enviava os estatutos da Biblioteca da Espanha. Considerando-se que na época a travessia interatlântica durava, em média, de dois a três meses, Francisco José dos Santos Marrocos atendia rapidamente às solicitações profissionais do filho.

Ao agradecer-lhe o despacho, o bibliotecário também conjecturava sobre as possibilidades de melhorias dentro da instituição: "Sobre este ponto, creio com toda a probabilidade que vão a aumentar-se [sic] os Ordenados dos Empregados, isto é, a cada um dos serventes a quantia de $100 \$ 000$ mais anualmente, e a mim mais 200\$000 réis, ficando assim com 600\$000 metálicos". Marrocos ainda via um horizonte profissional para além dos muros da biblioteca. "Ouço [o Conde de Aguiar] rosnar muito ao longe, em razão do meu exercício no Paço, dar-me mais de Ordenado outros $600 \$ 000$ réis, graduação de Oficial da Secretaria, e condecorado com o Hábito de Cristo", empolgava-se. ${ }^{209}$ Em junho do mesmo ano, Marrocos tinha em mãos o Plano da Biblioteca Pública, emitido para o Brasil em março. ${ }^{210}$

Estes episódios nos remetem para uma dimensão relevante no mundo luso-brasileiro, especialmente no que tange à comunicação interatlântica: a importância de delimitarmos quem são os interlocutores das correspondências. Neste caso, particularmente, é preciso salientar não apenas a figura do autor das cartas

\footnotetext{
208 Ibid., p. 93. [Carta N. ${ }^{9}$ 9].

209 Ibid., p. 101. [Carta N. $\left.{ }^{\circ} 12\right]$.

${ }^{210}$ Ibid., p. 136. [Carta N. $\left.{ }^{\circ} 25\right]$.
} 
- Luís Marrocos - mas, sobretudo, a de Francisco José, seu principal interlocutor. Para além de ser seu pai, Francisco José era um funcionário com acesso direto à documentação da Real Biblioteca d'Ajuda que havia ficado em Lisboa, sendo, ainda, um homem com grande experiência nas relações sociopolíticas da sociedade de corte, fosse como súdito da monarquia ou como bibliotecário régio.

O filho, Luís Joaquim, não apenas conhecia as relações políticas do pai, como também reconhecia (e respeitava) a sua vasta experiência profissional. Nesse sentido, apesar dos avanços e retrocessos na comunicação entre pai e filho, ao longo de uma década (1811-1821), é bem provável que Luís Joaquim tenha concebido o pai como seu orientador político e intelectual. ${ }^{211}$ Através dos "bons conselhos" advindos da figura paterna, Marrocos podia se movimentar de forma mais "tranquila" politica e socialmente na nova corte do Rio de Janeiro. O olhar experiente do pai ajudava-o a correr menos riscos, dentro e fora da Biblioteca Real.

211 Sobre a inconstância da comunicação entre pai e filho, cf. ARAÚJO, Ana Cristina. "Uma longa despedida..., Op. Cit., p. 15-16. Já quanto à relação de respeito à hierarquia familiar, é possível percebê-la em muitas de suas cartas. A seguir, selecionamos algumas delas que nos servem de bons guias. "vivo na esperança de ser algum dia mais do que sou: rogo portanto a Vossa Mercê me ajude com os seus conselhos para o bom acerto das minhas acções, e enviando súplicas aos Céu, para que me ilustre e ilumine." [Carta N. ${ }^{4}$, p. 84-85]; "Agradeço-te a remessa dos versos ao Botas, assim como as mais notícias; que me mandas, e a respeito de me escreveres menos vezes por eu não gastar tanto importe no Correio, não repares nisso, porque antes eu quero ler uma Carta tua, do que ver uma Ópera." [Carta N. o 25A, p. 115-116]; "Espero da sua bondade me tenha sempre na lembrança, favorecendo-me com o seu conselho, letras, amizade, bênção, sendo estes os bens, com o que desejo conservar-me, julgando-me mui[to] feliz na consideração de ser com a maior vaidade." [Carta N. ${ }^{\circ} 20$, p. 128]; "Depois de ficar ciente do conteúdo da Carta de Vossa Mercê, faço esta, que ainda não serve de resposta, mas é de prevenção ante omnia, a retractar-me de tudo que escrevi na Carta 5, que foi sem dúvida de escandalizar [...] não é minha tenção afrontá-lo, nem desobedecer-lhe em coisa alguma, antes mostrar para todos os modos o extremo de amor e respeito, que lhe é devido [...]. " [Carta N.o 35, p. 164]. 
As cartas trocadas entre a família Marrocos nesse período é uma fonte documental ainda pouco explorada pela historiografia luso-brasileira. Nesta pesquisa, sugerimos algumas leituras possíveis acerca da relação entre pai e filho, sendo nosso objetivo contribuir para um debate profícuo sobre a importância desses dois personagens para a história da estruturação da Real Biblioteca do Rio de Janeiro, em particular, e da política cultural joanina, em geral. Sendo por um lado a relação entre eles um tema que merece maiores pesquisas; por outro, é fato que Luís Joaquim alcançou um lugar de maior responsabilidade na corte, a partir de outubro de 1811. Desde então, passava a ser o responsável pela seção de manuscritos da Real Biblioteca. Sua narrativa sobre o episódio nos é muito profícua. Em reunião com o Visconde de Vilanova da Rainha, Marrocos soube que

[...] tendo sua Alteza Real pleno conhecimento da minha pessoa e conduta, e estando muito satisfeito dos bons desejos, que eu tinha de lhe servir bem, lhe tinha ordenado me chamasse logo e logo para ir tomar conta e cuidar do arranjamento [sic] e conservação dos Manuscritos da Biblioteca da Coroa (que Sua Alteza Real quis que permanecessem junto de Sua Pessoa) e dos mais Papéis, que sua Alteza Real ordenasse para o futuro. Que estava inteirado das boas informações do Senhor João Diogo ${ }^{212}$ a meu respeito, e como pessoa fidedigna me confiava este Cargo de segredo, importância e responsabilidade. [...] Faz-me muita honra esta distinção, por ser Sucessor de Frei António de Arrábida nesta incumbência, e principalmente pela especial lembrança de Sua Alteza Real em me chamar, sem eu o requerer. ${ }^{213}$

212 João de Barros Leitão de Carvalhosa.

213 MARROCOS, Luís Joaquim dos Santos. Cartas do Rio de Janeiro... Op. Cit., p. 84. [Carta N. ${ }^{\circ}$ 6] (Grifos do Original). 
Apesar de longa, a narrativa de Marrocos explicita-nos uma série de questões fundamentais à monarquia portuguesa. A primeira delas já é conhecida: D. João escolhia pessoalmente os lugares políticos de seus súditos e, para o sucesso de suas metas, não media esforços. ${ }^{214}$ No caso da atribuição ao novo cargo de Luís Marrocos, o Príncipe Regente não só foi um excelente observador da trajetória do ajudante de bibliotecário na corte, como também confiou no olhar de outros súditos considerados fiéis para deliberar sobre uma função de tamanha consideração. Em segundo lugar, o monarca pedia que a substituição dos profissionais ficasse em segredo, o que já denotava a grande autoridade dada aos manuscritos reais. Lilia Schwarcz aponta as diferenças entre os livros da biblioteca - considerados uma joia para expor ao público - e os manuscritos. Estes, segundo a autora, "cumpriam uma função política delimitada e reservada". ${ }^{215}$ Para exercerem devidamente o seu papel político, portanto, foram organizados em um criterioso catálogo produzido e classificado pelo bibliotecário. ${ }^{216}$ Por fim,

\footnotetext{
214 A historiadora Leila Mezan Algranti destacou que "o cargo público no estado absolutista dignificava os indivíduos, e sempre foi uma forma de conquista de status, de prestígio e até de título de nobreza por parte daqueles que o ocupavam." Algranti ressalta ainda que esses funcionários tinham perspectivas "de atrair a estima do rei, além de recompensas generosas pelos bons serviços prestados." Desse modo, os leais servidores de D. João não poupavam esforços para conquistar sua confiança que, na prática, significava um importante reconhecimento público além de chamar para si a estima e recompensa por parte do soberano. ALGRANTI, Leila Mezan. Livros de Devoção... Op. Cit., p. 225-226.

215 SCHWARCZ, Lilia. "Luís Joaquim dos Santos Marrocos”. In: NEVES, Lúcia Bastos Pereira das; VAINFAS, Ronaldo. Dicionário do Brasil Joanino... Op. Cit., p. 304. Sobre a importância dos manuscritos ver também MORAES, Rubens Borba de. Livros e Bibliotecas no Brasil colonial. São Paulo: Livros Técnicos e Científicos, 1979. p. 84.

216 Sobre o Catálogo, relatava ao pai: "Eu por ora vou continuando em meu trabalho: concluí um Mapa Sistemático da Classificação, como já anunciei à Vossa Mercê em outra [carta]; este Mapa hei-de [sic] mostrá-lo primeiramente ao Frei António de Arrábida, que me pediu essa preferência, e ao depois hei-de
} 
Marrocos se envaidecia de estar sob a mira do Príncipe Regente, uma vez que, na sociedade do Antigo Regime, estar próximo ao rei era um dos maiores prestígios almejados pelos cortesãos.

A ascensão de Luís Joaquim dos Santos Marrocos não foi vista com bons olhos por muitos palacianos. Segundo ele, por conta da nova função, passou a ser "vítima de intriga". No relato desses problemas ao pai, dizia ter sido obrigado a não ir ao Paço por dois dias sucessivos, já que tinha sido expulso do seu lugar de trabalho. Isto ocorreu, justificava, "não por motivos de honra, que me envergonhem, graças a Deus, mas porque queriam persuadir a Sua Alteza Real que eu não devia ver certos Papéis enquanto estes se conservassem na Sala de Manuscritos". O imbróglio foi rapidamente resolvido com a interferência do Visconde de Vila Nova da Rainha, que agiu em seu favor diretamente com D. João. ${ }^{217}$

A proteção do Visconde de Vila Nova da Rainha surtia efeito no olhar que o Regente tecia para Marrocos. No raiar de 1813, o bibliotecário tinha sob suas mãos a chave da Sala de Manuscritos. Tal honra era motivo de grande vaidade para o súdito real: "quem quiser ir a ela [sala] há-de [sic] vir primeiro à bajulação",

[sic] entregá-lo ao Visconde de Vila Nova da Rainha para este apresentar à Sua Alteza Real.” MARROCOS, Luís Joaquim dos Santos. Cartas do Rio de Janeiro... Op. Cit., p. 143. [Carta N. ${ }^{\circ}$ 28]. A pesquisadora Lilia Schwarcz cita a existência desse Catálogo, que segundo ela, contava com 75 páginas, sendo dividido em 08 temas: Política (180 documentos), Teologia (76 documentos), Direito Canônico (86 documentos), Direito Civil (64 documentos), História Eclesiástica (83 documentos), História Civil (33 documentos), História Literária (04 documentos), Ciências, Belas Artes e Belas Letras. (44 documentos). Apesar de citar em detalhes a documentação, a autora não indica a referência documental. Marrocos, tampouco, o faz em suas cartas. Portanto, como não tivemos acesso à documentação, nos limitamos apenas em reiterar, por Schwarcz, a sua possível existência. Cf. SCHWARCZ, Lilia. A longa viagem... Op. Cit., p. 284.

217 MARROCOS, Luís Joaquim dos Santos. Cartas do Rio de Janeiro... Op. Cit., p. 139. [Carta N. ${ }^{\circ}$ 26]. 
vangloriava-se. ${ }^{218}$ Coincidentemente, neste mesmo período, o monarca determinava o conserto e reparo na livraria. Para tal intento, o Real Erário concedia $100 \$ 000$ réis por mês para cobrir as despesas. "Confesso que ficará uma Casa mui[to] linda, e mui[to] bem arranjados os Livros." Quanto à finalização do trabalho com as obras, informava: "Abriram-se já os últimos 67 Caixões de Livros que ainda existiam fechados, e tive grande satisfação de ver louvado o bom acondicionamento deles nos ditos Caixões". ${ }^{219}$

Enfim, em 1814 a Real Biblioteca do Rio de Janeiro era aberta ao público. Sobre esse evento, destacamos a observação de Padre Perereca.

[...] a Real Biblioteca tem sido muito bem arranjada, e repartida por diversas salas, segundo as diferentes classes de objetos científicos, ou de literatura de que tratam os livros de que ela se compõe, os quais estão hoje por uma ordem muito metódica, e fácil de se encontrar qualquer deles, quando são procurados pelos estudiosos. Esta Real Biblioteca tem chegado a ser a primeira, e a mais insigne, que existe no Novo Mundo, não só pelo copioso número de livros de todas as ciências, e artes, impressos nas línguas antigas, e modernas, cujo número passa de sessenta mil volumes, mas também pela preciosa coleção de estampas, mapas, manuscritos, e outras ricas e singulares coisas, que muito a enriquecem, e que cada vez mas se aumentam devido a munificência de Sua Alteza Real. ${ }^{220}$

A descrição do religioso nos coloca a par do trabalho dos funcionários da instituição entre os anos de 1810 e 1814 . O espaço organizado em salas específicas, as coleções distribuídas por temas e as obras classificadas. Um trabalho de tal monta, segundo

${ }^{218}$ Ibid., p. 167. [Carta N. $\left.{ }^{\circ} 37\right]$.

219 Ibid., p. 170. [Carta N.o 37].

220 SANTOS, Luiz Gonçalves dos. Memórias para servir... Op. Cit., p. 425-426. 
o clérigo, contou com a ativa colaboração do Príncipe Regente, que não só se empenhava em mover toda uma equipe especializada para a transladação das preciosidades intelectuais da Coroa, como também se preocupava em manter viva a constituição do acervo, juntamente com os seus bibliotecários, responsáveis pela aquisição de novas obras e zelo do espaço. De fato, como já mostrou Rubens Borba de Moraes, a Biblioteca Real do Rio de Janeiro foi enriquecida constantemente. ${ }^{221}$

Além de Luís Marrocos ter conseguido a Propina da Impressão Régia, que na prática enviava uma cópia para a Biblioteca "de tudo o quanto se tem impresso, e houver de imprimir-se"222, em 1811 a instituição recebeu, por doação o espólio literário de Frei Mariano da Conceição Veloso, que contava com cerca de 2.500 livros. Isto sem contar com as estampas e os desenhos originais da Flora Fluminensis. ${ }^{223}$ No final de 1812, D. João determinava que viesse de Lisboa um exemplar de cada obra produzida pela extinta tipografa do Arco do Cego, cujo material chegou ao Rio de Janeiro em setembro de 1813. Dois anos depois, em 1815, a realeza comprava a biblioteca de Manuel Inácio de Silva Alvarenga, que, inclusive, tinha obras proibidas em seu acervo, de quase 1.600 volumes ${ }^{224}$; em 1818 era vez de adquirir a coleção do arquiteto português dos teatros joaninos de São Carlos (Lisboa) e São João (Rio de Janeiro), José da Costa e Silva, que, entre as

\footnotetext{
${ }^{221}$ MORAES, Rubens Borba de. Livros... Op. Cit., p. 85.

222 MARROCOS, Luís Joaquim dos Santos. Cartas do Rio de Janeiro... Op. Cit., p. 99. [Carta N. $\left.{ }^{\circ} 11\right]$.

${ }^{223}$ Para a observação de Marrocos sobre a doação da coleção de Veloso, ver MARROCOS, Luís Joaquim dos Santos. Cartas do Rio de Janeiro... Op. Cit., p. 93. [Carta N. 9].

${ }^{224}$ Sobre as especificidades da livraria de Silva Alvarenga, ver: TUNA, Gustavo Henrique. "A livraria de Manuel Inácio Silva Alvarenga: representante das Luzes na América Portuguesa?" In: ALGRANTI, Leila M.; MEGIANI, Ana Paula. (Org.). O Império por escrito..., p. 265-276.
} 
raridades, tinha "uma valiosa série de estampas, manuscritos e, principalmente, grande número de desenhos originais de mestres da renascença italiana”. ${ }^{225}$ Em 1822, um ano depois da volta de D. João para Lisboa, D. Pedro arrematava a célebre livraria do Conde da Barca. ${ }^{226}$ Como já salientou Lilia Schwarcz, o acervo da Real Biblioteca também contou com pequenas doações, porém, de grande valia. Se entre 1817 e 1820 foi registrada a entrada de 317 obras, os seus benfeitores eram a elite do Paço. Para além de D. João, seus ministros agiam constantemente em prol do esplendor do espaço. Entre os doadores, Schwarcz destacou o Marquês de Marialva, Thomaz Antonio Vilanova Portugal e Francisco Borja Garção Stockler (dois ministros e um censor régio). ${ }^{227}$ Ademais, a pesquisa de Lúcia Pereira das Neves já demonstrou o interesse desses homens de prestígio em doar suas obras. Esta atitude, segundo a autora, reafirmava a importância da Biblioteca como instância simbólica de consagração da monarquia, além de reiterar o papel político e social desses sujeitos na sociedade de Corte. ${ }^{228}$

Em relação aos dias de funcionamento da Real Biblioteca, Padre Perereca nos informa que "exceto nos domingos, dias santos e feriados por motivos de anos das pessoas reais, ou por alguma causa pública, a instituição estava sempre aberta, e patente, tanto de manhã quanto de tarde, a todas as pessoas, que a querem frequentar". ${ }^{29}$ Se considerarmos as características do calendário

\footnotetext{
225 MORAES, Rubens Borba de. Livros... Op. Cit., p. 85.

226 O exame detalhado da biblioteca do Conde da Barca foi tema de investigação da historiadora Maria Beatriz Nizza da Silva. Para a análise da autora, ver as seguintes obras: D. João: príncipe e rei no Brasil. Lisboa: Livros Horizonte LDA, 2008. p. 88-89; e A cultura luso-brasileira: da reforma da universidade à independência do Brasil. Lisboa: Editorial Estampa, 1999. p. 139-141.

227 SCHWARCZ, Lilia. A longa... Op. Cit., p. 281.

228 NEVES, Lúcia. “O livro para se fazer nele memória..., Op. Cit., p. 295.

229 SANTOS, Luiz Gonçalves dos. Memórias para servir... Op. Cit., p. 426.
} 
real - pautado pelo viés religioso e político - os compromissos da monarquia no espaço público do Rio de Janeiro eram constantes, podendo ser contabilizados pelas paradas militares, dias santos, datas natalícias da realeza etc. ${ }^{230} \mathrm{Tal}$ fato nos mostra que, provavelmente, o acesso do público ao acervo da Real Biblioteca tenha sido bem menor do que quer nos fazer crer o Padre Perereca. De qualquer forma, as cartas de Marrocos nos indicam que as visitações ao locus eram uma prática cotidiana, pelo menos para os membros da realeza e da elite intelectual da corte, incluindo-se aí os viajantes. ${ }^{231}$ É o caso de Lord Strangford, que, em abril de 1815, voltava para a Inglaterra levando consigo dois títulos da Real Biblioteca: O Cancioneiro (que a instituição tinha outro exemplar) e o Blasonero geral, que se perdia, pois era único exemplar. ${ }^{232}$ Ainda de acordo com Luís Joaquim, pouco antes da abertura da instituição, era comum a presença quase diária da família real pelos corredores da biblioteca que, segundo ele, se preparava para inaugurar com todo asseio e magnificência. ${ }^{233}$

Dentro desse cenário intelectual em que o livro e a leitura emergiam como instrumentos fundamentais na formação de novas ideias críticas ao status quo e do delineamento sutil, mas definitivo, de uma nova cultura política ${ }^{234}$, emergem-nos algumas dúvidas. Apesar da rica descrição do Padre Perereca sobre a

\footnotetext{
230 Para uma análise histórica sobre o significado do calendário no período joanino, ver LOPES, Emílio Carlos. Festas Públicas... Op. Cit., p. 87-124.

231 Para conhecer os possíveis visitadores da Biblioteca Real, ver SILVA, Maria Beatriz Nizza da. D. João: príncipe e rei no Brasil. Lisboa: Livros Horizonte LTDA, 2008. p. 82-83; SCHWARCZ, Lilia. A longa.... Op. Cit., p. 277.

${ }^{232}$ MARROCOS, Luís Joaquim dos Santos. Cartas do Rio de Janeiro... Op. Cit., p. 284. [Carta N. ${ }^{\circ}$ 79].

${ }^{233}$ Ibid., p. 246. [Carta N. ${ }^{\circ} 63$ ].

${ }^{234}$ Sobre as transformações na cultura política em fins do período joanino, destacamos o trabalho de NEVES, Lúcia Maria Bastos P. Corcundas, constitucionais e pés de chumbo: Op. Cit.
} 
organização interior do espaço, como as estantes foram dispostas? E a catalogação das obras? Que tipos de livros estavam à disposição dos leitores? Como já bem demonstraram os pesquisadores Rubens Borba de Moraes e Maria Beatriz Nizza da Silva, devido à grandiosidade do acervo não é possível termos uma noção exata dos volumes e tipos de livros existentes na livraria régia ${ }^{235}$; a despeito disso, a conservação de um Catálogo da Real Biblioteca intitulado "Catálogo por ordem alfabética das iniciais dos títulos de uma série de obras pertencentes à Real Biblioteca" nos dá importantes indicações sobre o interior do espaço. ${ }^{236}$

O manuscrito nos revela a existência de 306 títulos divididos em 65 estantes. Sem data e autoria, as obras foram catalogadas por ordem alfabética, de "A" a "V" e os temas respeitam as escolhas literárias clássicas do século XVIII. De acordo com Lúcia Pereira das Neves, a classificação das obras da Real Biblioteca do Rio de Janeiro tinha por base o critério retirado do Catálogo do Conde da Barca, dividido em cinco categorias: Jurisprudência, Ciências e Artes, Belas Letras, História e Teologia. ${ }^{237}$ Dentro dessas áreas do saber, o autor elegeu a História como a grande protagonista. As obras referentes ao tema aparecem em quase todo o alfabeto, porém, a maior referência esteve circunscrita à letra " $H$ "

${ }^{235}$ MORAES, Rubens Borba de. Livros... Op. Cit., p. 84; SILVA, Maria Beatriz Nizza da. A cultura luso-brasilera... Op. Cit., p. 145. Segundo Moraes, a investigação dos Catálogos da Coleção Barbosa Machado, Catálogo da Exposição Permanente dos Cimélios da Biblioteca Nacional (Rio, 1885) e o Catálogo dos Incunábulos da Biblioteca Nacional nos dão uma ideia mais precisa do acervo. (p. 84). Já Nizza da Silva, cita a existência do "Catálogo por ordem alfabética das iniciais dos títulos de uma série de obras pertencentes à Real Biblioteca". (p. 145).

${ }^{236}$ BNRJ. Catálogo por ordem alfabética das iniciais dos títulos de uma série de obras pertencentes à Real Biblioteca. Seção de Manuscritos. I - 13,02,056.

237 NEVES, Lúcia. “O livro para nele se fazer memória..., Op. Cit., p. 279. 
do Catálogo, somando, ao todo, 55 títulos. ${ }^{238} \mathrm{E}$ os subtemas são bem amplos. Da História Militar e Naval à História da Botânica, perpassando a História Antiga, História da Europa Ocidental, História Oriental, História Eclesiástica e, obviamente, a História de Portugal. ${ }^{239}$ Esta escolha não é, de modo algum, inusitada. Pelo contrário, dialogava com a tendência dos livreiros europeus do período, que no início do século XIX passaram a manifestar importância crescente entre os livros de História. ${ }^{240}$

Porém, de forma mais geral, entre os subtítulos há o predomínio para as obras militares, que compõem um total de 23 livros. Entre as Ciências, a valorização da Física e da Matemática é patente, inclusive com obras de Belidor e Saint Remy. Quanto às obras de mineralogia, astronomia e agricultura, mesmo que em menor número, mereceram destaque por todo o Catálogo. Nas Belas Letras, a ênfase deu-se para os Dicionários. Dentro dessa classificação, contudo, também encontramos novelas, poesia e obras de retórica.

Ademais, a deferência à produção intelectual francesa seja através da seleção de autores clássicos ou de obras traduzidas para o francês - é indiscutível: composto pela quase totalidade das obras selecionadas (226), o Catálogo privilegia temas da literatura política e das belas-letras, incluindo-se aí o teatro. Entre as celebridades da República das Letras, encontramos Montaigne, Erasmo de Rotterdam, Maquiavel, Bossuet, Fenellon e Corneille.

238 Sobre a entrada de livros e periódicos na Real Biblioteca entre os anos de 1817 e 1824, ver NEVES, Lúcia Maria Bastos Pereira das. "O livro para se fazer memória de todas as obras que entrarem na Real Biblioteca” In: ALGRANTI, Leila Mezan; MEGIANI, Ana Paula. (Org). O Império por escrito: Op. Cit., p. 277-296.

239 Vide Catálogo, em Anexo [ $\left.\mathrm{n}^{\circ}\right]$

${ }^{240}$ GUEDES, Fernando. O livro e a leitura em Portugal. Subsídios para a sua história. Séculos XVIII e XIX. Lisboa: Ed. Verbo, 1987. p. 135. 
Quanto aos filósofos iluministas, a referência foi Voltaire. Com Annales de L'Empire depuis Charles Magne (1754), Siecle de Luis 14 (1756) e Histoire universelle, o autor sedicioso também estava presente. Todos ao alcance dos leitores nas estantes da Biblioteca. O Catálogo também prestigia títulos em português (55), sendo as menções, obviamente, para atores nacionais renomados. Obras completas do Padre Vieira, Escola de Belém Jesus Nascido no Presépio (1730), por Alexandre de Gusmão e três obras de Manuel de Faria \& Sousa (Histoire del Reyno de Portugal (1730), Nobi lario do Conde de Barcellos Dom Pedro (1646) e Rimas Varias de Luís [de] Camões (1685)) são os destaques do acervo lusitano. Em menor escala ainda encontramos obras em latim (9), italiano (4) e espanhol (9). Como bem analisa Roger Chartier, "Graças à difusão dos catálogos, o mundo fechado das bibliotecas singulares pode ser transformado em um universo infinito de livros assinalados, recenseados, visitados, consultados e, eventualmente, emprestados" ${ }^{241}$

Reiteramos que o ato de classificar é guiado por critérios de relevância particulares ao autor do manuscrito ${ }^{242}$, que elevam a classificação como um exercício de poder. Segundo Robert Darnton, "um livro colocado errado na prateleira pode desaparecer para sempre [...]. Toda ação social flui através de fronteiras determinadas por esquemas de classificação, tenham ou não uma elaboração tão explícita quanto a de catálogos de bibliotecas". ${ }^{243}$ Por este prisma, mesmo sem conhecermos a data e a identidade do autor do Catálogo, há a hipótese de que ele tenha sido produzido por um dos bibliotecários régios, uma vez que o título

${ }^{241}$ CHARTIER, ROGER. A ordem dos livros... Op. Cit., p. 74.

${ }^{242}$ Discutimos a importância dos critérios de relevância para autores de Catálogos Bibliográficos no item I deste Capítulo.

${ }^{243}$ DARNTON, Robert. O grande massacre de gatos... Op. Cit., p. 249. 
do manuscrito faz referência à "Real Biblioteca" (denominação da instituição até 1825, quando passou a ser Biblioteca Imperial e Pública da Corte). Neste sentido, é plausível supormos que as obras selecionadas, talvez sejam as que mais interessavam à Coroa adquirir. "Estabelecer categorias e policiá-las é, portanto, assunto sério", analisa Darnton ao investigar as atividades dos filósofos dentro da Encyclopédie como empreendimento cultural. Para termos uma ideia da composição das estantes, vejamos um exemplo:

Tabela 2. A estante n. ${ }^{\circ} 56$ da Real Biblioteca do Rio de Janeiro

\begin{tabular}{|c|c|}
\hline Títulos & $\begin{array}{l}\text { Local/ ano de } \\
\text { publicação }\end{array}$ \\
\hline $\begin{array}{l}\text { Astronomie Nautique ou Elements d'Astronomie por un } \\
\text { Observatoire fixe, ou mobile .................par Maupertais. }\end{array}$ & Paris \\
\hline $\begin{array}{l}\text { Abrege de la Perfection Christienne du Pere Affone } \\
\text { [ilegível] Jezuitte. }\end{array}$ & Nantes, 1744 \\
\hline $\begin{array}{l}\text { Apparas Royal ou Nouveau Dictionnaire Francaise \& Latin } \\
\text { Nouvelle Edition Paris. }\end{array}$ & Paris, 1752 \\
\hline Cathecisme Historique par Heury. & 1745 \\
\hline $\begin{array}{l}\text { Dictionnaire Abregé de la Bible pour la connoissance des } \\
\text { Tableaux Historique. }\end{array}$ & Lion, 1756 \\
\hline $\begin{array}{l}\text { Dialogue sur la eloquence \& de la chaire en particulier } \\
\text { par Fenellon. }\end{array}$ & Paris, 1753 \\
\hline $\begin{array}{l}\text { Discours sur la Histoire Universelle par Jaque Begnigne } \\
\text { Bossuet. }\end{array}$ & Paris, 1741 \\
\hline $\begin{array}{l}\text { Geographie Universelle abregée avec les generalités de Fran- } \\
\text { ce \& les Villes ou l'on Cat Monnoye. }\end{array}$ & Lion, 1672 \\
\hline Gentilhomme Christien quivent se santifies. & Londres, 1719 \\
\hline $\begin{array}{l}\text { Historie Des Empereurs Romaine ecrite en Latin por Sue- } \\
\text { tone \& Traduite por Dateil avec Nottes \& Figures. }\end{array}$ & Lion, 1689 \\
\hline Historie Des Variations de l'Églize Protestante por Bossuet. & Paris, 1740 \\
\hline Historie Sur les Anglais \& Français \& sur les Voyages. & 1725 \\
\hline
\end{tabular}


Heures a luzage des Pensionnaires des jesuites por Le Père Troisel.

Letres de Madame du Montier a la Marquise de XX a fille \& le Reponses.

Bruxelas, 1756

Memoirs de Montecuculi Generalissime des Troupes de L'Empereur Itransburg.

Memoirs de Duque Trouin Lientenant General des Armées Amsterdã, Navales de France. 1755

Memoirs de Duque Trouin Lientenant General des Armées Navales de France.

Amsterdã, 1755

Memoirs contenant leprecis des faits avec pieces justificatives pour reponse aux Ministres Anglois.

Paris, 1756

Manuel des Ceremonies Romaines. 1691

Mœurs des Iseralites \& des Christiens por Fleury. Paris, 1755

Oeuvres de Marmontel. 1757

Revolution de Portugal par L'Abée du Vertot.

Haia, 1755

Traitté de Lortografie française en forme de Dicttionnaire avec des Nottes Critiques.

1755

Vie de Mahomet Traduite \& Compilée de Laceran des Traductions authentiques \& meilleurs Autheurs Arabes par Jean Gagnus.

Amsterdã,

1748

Como podemos observar, há uma grande variedade de títulos na estante 56. Obras científicas, dicionários, livros de História, Geografia, Ortografia, Literatura e Política. Três escritores, todavia, nos chamam a atenção. Fénelon (1651-1715), um autor muito lido por D. João VI ${ }^{244}$, Jacques Bossuet (1627-1704), um dos mais importantes teóricos do absolutismo no século XVII, e Marmontel (1723-1799), literato francês de renome, que já tinha

${ }^{244}$ PEDREIRA, Jorge; COSTA, Fernando Dores. D. João VI... Op. Cit., p. 43. 
caído no gosto português desde meados de $1800 .{ }^{245} \mathrm{O}$ que notamos em todo o Catálogo, mas, especificamente, nesta estante, é que a seleção dos livros para comporem o mesmo espaço não obedece, necessariamente, um critério temático, temporal ou por nações. A variedade de títulos parecia ser a regra. Ressaltamos ainda que esta observação necessita de uma investigação mais detalhada em todo o Catálogo, para que possamos tirar outras conclusões mais precisas. Nosso objetivo na análise deste manuscrito em específico era conhecer em linhas gerais o que tinha dentro da biblioteca e perceber as nuanças da atividade do bibliotecário; por essas razões, selecionamos uma estante, em particular, apenas a título de exemplo. A análise de cada uma dessas estantes talvez seja uma indicação para futuras pesquisas.

Coincidentemente, no mesmo ano em que a Real Biblioteca abria, definitivamente, as portas ao público leitor, a Europa vivia o fim do pesadelo napoleônico. Com a queda de Bonaparte e a volta da monarquia francesa ao poder, com Luís XVIII, tentava-se restabelecer a velha ordem no Continente, sendo o Congresso de Viena o símbolo máximo dessa tentativa. No Rio de Janeiro, as comemorações públicas (oficiais ou não) pelas ruas da cidade ${ }^{246}$ ou através do discurso da Gazeta do Rio de Janeiro exaltavam a alegria com o fim de uma era "maldita". ${ }^{247}$ Se esta situação configurava um alívio político para a monarquia portuguesa, não havia mais razões para D. João e seu séquito permanecerem no Brasil. A volta da realeza para Lisboa, a partir de então, seria uma questão de tempo? Eis a grande interrogação.

245 GUEDES, Fernando. O livro e a leitura em Portugal... Op. Cit., p. 138.

${ }^{246}$ MARROCOS, Luís Joaquim dos Santos. Cartas do Rio de Janeiro... Op. Cit., p. 266. [Carta N. ${ }^{\circ}$ 70].

247 Sobre o discurso da Gazeta do Rio de Janeiro sobre a queda de Napoleão Bonaparte, ver MEIRELLES, Juliana. Imprensa e poder... Op. Cit., p. 127-133; STOIANI, Raquel. Napoleão visto.... Op. Cit., p. 134-164. Disponível em: <http:// www.teses.usp. br/teses/disponiveis/8/8138/tde-19022010-125213/>. 
Em meio às conjecturas acerca do possível retorno da realeza nos dois lados do Atlântico, encontramos duas cartas sui generis de Luís Joaquim dos Santos Marrocos. Sobre os rumores ocorridos no Rio de Janeiro, em 12 de maio de 1814, o bibliotecário dizia ao pai que "nunca se pensou menos nessa matéria, do que agora". ${ }^{48}$ Menos de um mês depois, as súplicas dos Governadores do Reino já se faziam públicas e constantes na Corte. Para Marrocos, apesar das embarcações de diversas nações no cais, que congratulavam a aliança com a Coroa portuguesa, os preparativos para o retorno ainda eram incertos. Sobre a sua situação particular e a da livraria, contudo, Luís Joaquim fazia uma curiosa conjectura:

Quando Sua Alteza Real se retirar para Lisboa, ou levará consigo a Livraria, ou não; se a levar, creio não nomeará pessoas de fora, quando tem empregados antigos para tratar dela, até que chegue a ocasião de embarcar. Os dois Padres, que aqui se acham, não podem ficar, um por ser Confessor de sua Alteza as Senhoritas, e o outro por ser Companheiro do Confessor, que por força hão-de [sic] acompanhar suas Amas: na falta destes dois Padres não há outro de Casa, em quem possam pôr a albarda, senão em mim: e que será de mim, se eu disser que não quero, e que só quero ir-me embora? ${ }^{249}$

Mesmo sendo apenas suposições sobre o possível destino da realeza portuguesa, seu relato colocava em cena a problemática da materialidade do poder monárquico, simbolizado pela existência da Livraria. Ficar ou partir? Esta dúvida crucial tornou-se um tema de reconhecida centralidade no alto escalão

248 MARROCOS, Luís Joaquim dos Santos. Cartas do Rio de Janeiro... Op. Cit., p. 256. [Carta N. $\left.{ }^{\circ} 67\right]$.

${ }^{249}$ Ibid., p. 261. [Carta N. $\left.{ }^{\circ} 69\right]$. 
governamental, tendo, inclusive, sido, à época, objeto de reflexão do conselheiro Silvestre Pinheiro Ferreira (1814). ${ }^{250}$ A partir do final de 1815, quando o Brasil foi elevado a Reino Unido a Portugal e Algarves, os contornos em torno da definição política diante da questão "qual deveria ser o lugar hegemônico do poder no mundo luso-brasileiro", na acepção de Ana Rosa Cloclet da Silva, começavam a endossar a patente fragilidade do Império e do sistema absolutista, cuja predominância para a valorização do Brasil na conjuntura imperial passava a ser cada vez mais clara. ${ }^{251}$

Segundo a autora, se no Brasil a repercussão do novo status político foi interpretada pelas "múltiplas noções de unidade, igualdade e identidade"252, em Portugal forjava-se entre os Governadores do Reino "um sentimento de reação à nova categoria política do Brasil, acirrando o processo de reivindicação pelo retorno da Monarquia à sua antiga sede". ${ }^{253}$ Neste contexto, a particular preocupação do bibliotecário em transladar novamente a Real Biblioteca para a capital do Império, independentemente de ser Lisboa ou Rio de Janeiro, parecia ser, antes, uma inquietação da própria Coroa, que concebia este locus de saber como símbolo máximo de força, vitalidade e independência da monarquia luso-brasileira.

As livrarias foram consideradas espaços de saber de suma importância para a política cultural joanina em fins do Setecentos

\footnotetext{
250 Sobre as ideias de Silvestre Pinheiro Ferreira acerca da volta de D. João VI, ver seu escrito "Memórias Políticas sobre os abusos gerais e o modo de os reformar e prevenir a revolução popular redigidas por ordem do Príncipe Regente no Rio de Janeiro em 1814 e 1815. In: Revista Trimestral do Instituto Histórico Geográfico e Etnográfico do Brasil, tomo XLVII. parte.1. Rio de Janeiro: Typografia Universal de H. Laemmert e \&, . 1884.

251 SILVA, Ana Rosa Cloclet da. Inventando a Nação:... Op. Cit., p. 246-252.

252 Ibid., p. 250 (Grifos do Original).

253 Ibid., p. 254.
} 
e início do Oitocentos. Apenas na Corte, a Coroa portuguesa gerenciou o nascimento de dois locus: a Real Biblioteca do Rio de Janeiro, e a biblioteca da Academia dos Guarda-Marinhas $(1810)^{254}$; isto sem contar com as principais livrarias conventuais de São Bento e São Francisco, existentes desde o século XVIII. Porém, como nos relembra Rubens Borba de Moraes, a divulgação da cultura não estava presa exclusivamente às livrarias dessas instituições. Para além dos estabelecimentos já citados, ainda funcionavam na cidade diversos institutos de estudos superiores criados pelo governo, tais como a Real Academia Militar, o Laboratório Químico-Prático, a Academia Médico-Cirúrgica, o Arquivo Militar e a Academia dos Guarda-Marinhas. ${ }^{255}$

Quanto ao restante do país, o grande empreendimento foi a Biblioteca Pública da Bahia. O Plano para o estabelecimento deste espaço na cidade de Salvador, além de ter sido aprovado pelo Conde dos Arcos, governador da capitania, foi veiculado n'O Investigador Portuguez, na sua edição de estreia, em julho de 1811. Mesmo tendo sido uma "inciativa privada da elite culta da segunda cidade do Brasil" 256 , o locus teve total apoio da Coroa, que disponibilizou as páginas do seu jornal em Londres para a divulgação do projeto. Esta postura reitera, mais uma vez, o uso da imprensa interatlântica como mola-mestra dos projetos

${ }^{254}$ De acordo com Maria Beatriz Nizza da Silva, este locus de saber contou com um Catálogo, concluído em 1812, sendo um espaço voltado exclusivamente para o estudo das Ciências em geral, com destaque para as Ciências Naturais, Ciências Matemáticas, Ciências e Artes Navais, Ciências e Artes Militares de Terra e também a Polimatia, que abarcava uma ampla gama de conhecimentos. SILVA, Maria Beatriz Nizza da. A cultura luso-brasilera... Op. Cit., p. 146-148. Para uma análise mais profunda do espaço, ver artigo da mesma autora: "A livraria Pública da Baía em 1818: obras de História”, Revista de História. (São Paulo), n.87., 1971. p. 225-239.

255 MORAES, Rubens Borba de. Livros... Op. Cit., p. 87.

256 SILVA, Maria Beatriz Nizza da. A cultura luso-brasilera... Op. Cit., p. 142. 
culturais sustentados pelo governo joanino. Para a vigência do Plano, de autoria de Pedro Gomes Ferrão Castelo Branco, Nizza da Silva relata que

[...] convidavam-se os sócios a ali depositarem as suas bibliotecas particulares, ou pelo menos algumas obras que pudessem separar-se. Quem assim procedesse teria o seu nome divulgado na gazeta ${ }^{257}$ e seria considerado "bem-feitor [sic] do público, amigo da pátria e zeloso dos verdadeiros interesses do soberano". O autor do Plano foi o primeiro a dar o exemplo, oferecendo em doação perpétua todos os seus livros, além de $50 \$ 000$ réis para o fundo inicial da Livraria Pública. ${ }^{258}$

A abertura da livraria deu-se em agosto de 1811. Sete anos depois, em 1818, quando o espaço passava a receber as duplicatas da Real Biblioteca do Rio de Janeiro, o seu acervo era de 5.361 obras. ${ }^{259}$ Com uma ampla variedade de temas - da literatura de viagem à ciência, perpassando a literatura europeia, seu conteúdo, segundo Nizza da Silva, correspondia verdadeiramente aos interesses de leitura dos sócios, já que a encomenda dos livros dependia de suas escolhas. Estas, entretanto, tinham que ser aprovadas previamente pelos censores. ${ }^{260}$

O governo joanino ainda dirigiu deste lado do Atlântico os destinos das principais bibliotecas reais lisboetas, assim como endossou o projeto dos negociantes portugueses exilados na Inglaterra referente à estruturação da Biblioteca Lusitana em Lon-

\footnotetext{
257 Idade d'Ouro do Brasil.

258 SILVA, Maria Beatriz Nizza da. A cultura luso-brasilera...Op. Cit., p. 143.

259 "Catálogo dos livros que se acham na Livraria Pública da cidade da Baía, em maio de 1818” Apud SILVA, Maria Beatriz Nizza da. A cultura luso-brasilera... Op. Cit., p. 143.

260 Ibid., p. 145.
} 
dres. No gerenciamento dos espaços do Reino alguns eventos nos chamam a atenção. Em maio de 1812, por exemplo, o Príncipe Regente pedia a Ribeiro dos Santos que enviasse (pela secretaria do Estado dos Negócios Estrangeiros e da Guerra) a relação dos empregados na Biblioteca Pública da Corte, com as devidas "declarações e explicações" sobre a rotina dos funcionários e do estabelecimento. ${ }^{261}$ Dois meses depois, D. João determinava que o mesmo bibliotecário recebesse e guardasse "na devida arrecadação os livros pertencentes ao Ex. ${ }^{\circ}$ Marques de Alorna, que na mesma Biblioteca forem mandados entregar pelo Intendente $\mathrm{Ge}$ ral da Polícia”."262

As queixas e pedidos dos súditos reais vinculados a esses espaços também chegavam às mãos do monarca e, por vezes, eram atendidos. Em 1814, Antonio Ribeiro dos Santos fazia duas reclamações aos governadores do Reino: a falta de estantes "para se arranjarem muitos dos livros que têm acrescido à Biblioteca Pública", e a necessidade de se arrumar um novo ajudante, uma vez que José Gonçalves Ramiro, oficial da outra Biblioteca não servia o seu cargo há dois anos. Do Rio de Janeiro, D. João mandava "expedir as ordens necessárias para se aproximarem as estantes precisas" e ordenava que "se o dito oficial não for servir com efetiva residência como deve", prometia colocar outro em seu lugar. ${ }^{263}$

Para além das questões burocráticas, o Príncipe também estava a par das aquisições de novas obras e das traduções que

\footnotetext{
261 Aviso em que manda pedir uma relação dos empregados na Biblioteca. BNP. Seção de Reservados. Cód. 10612.

${ }^{262}$ Aviso em que manda receber os livros do Ex. Marquês de Alorna. BNP. Seção de Reservados. Cód. 10612.

263 Aviso em que manda servir José Gonçalves Ramiro com efetiva residência. BNP. Seção de Reservados. Cód. 10612.
} 
cotidianamente ocorriam. Em 1816, por exemplo, o governador do Reino, João Antonio Salter de Mendonça, avisava Antonio Ribeiro dos Santos sobre os trâmites para a tradução da Eneida. "El Rei Nosso Senhor manda remeter a V. S. ${ }^{\text {a }}$ o manuscrito original da tradução da Eneida de Virgílio por Leonel da Costa, para guardar na Real Biblioteca Pública da Corte, com a cautela que merece uma obra de tal preço." ${ }^{264}$ A ordem real ainda determinava que o bibliotecário fizesse uma cópia do dito manuscrito, conservando-a na Biblioteca, uma vez que esta seria usada quando fosse autorizada a impressão do livro. Por fim, em maio de 1816, o Regente decretava a aposentadoria de Antonio Ribeiro dos Santos, "tomando em consideração [sua] avançada idade, moléstias e bons serviços", e nomeava para o mesmo cargo o Doutor Joaquim José Ferreira Gordo, que, além de membro do Conselho Real, ainda era prelado da Santa Igreja de Lisboa. O despacho era enviado para o Reino com a rubrica do próprio D. João e do Marquês de Aguiar, ministro e assistente no Despacho do Real Gabinete, e presidente do Real Erário. ${ }^{265}$

Já o projeto da Biblioteca Lusitana em Londres foi veiculado n'O Investigador Portuguez em Inglaterra, em novembro de 1815. Este concebia o locus como um ponto de reunião comum da comunidade portuguesa, onde os sócios poderiam consagrar-se aos deleites da literatura nacional, a base do fortalecimento do patriotismo, conservarem a pureza de sua língua, "que mui arriscados andam à viciar e perder, vivendo em país estrangeiro sem o próprio antídoto" e ainda se instruírem "nas histórias, e mais coisas de sua nação, que é obrigação de todos não ignorar, e que,

264 Aviso em que remete a tradução da Eneida por Leonel da Costa. BNP. Seção de Reservados. Cód. 10612.

265 Decreto da aposentadoria do Bibliotecário Maior Antonio Ribeiro dos Santos e, nomeação de D. Joaquim José Ferreira Gordo para o dito lugar. BNP. Seção de Reservados. Cód. 10612. 
em ponto de ricas, e interessantes, por nenhuma das modernas são excedidas." A biblioteca também contaria com mapas, gazetas e jornais das mais diversas nações. ${ }^{266}$

Nos meses de julho e agosto de 1816, O Investigador publicou duas cartas referentes ao tema. Escrita sob o pseudônimo de "BIBLIOMANÍACO", a pimeira correspondência pedia informações sobre o espaço. "[...] li ainda fora da Inglaterra tanto no seu Jornal como nos outros portugueses, que se ia estabelecer uma Biblioteca Lusitana em Londres, acabo agora de aqui chegar, e o meu primeiro cuidado foi perguntar pela dita Biblioteca, de que ninguém me tem sabido dar notícia”. O autor ainda solicitava o endereço da "Dulcineia encantada", inquirindo o número da casa em que ela vivia. ${ }^{267}$

No número seguinte, o jornal publicava uma resposta ao "Inquiridor". Sob o pseudônimo de "BIBLIÓFILO", o autor adentrava em uma polêmica pública, justificando as razões para a demora do empreendimento: "Dirigi-me portanto a um dos promotores da mencionada Biblioteca; e observando a nota do Bibliomaníaco, publicado no seu Jornal, disse: - 'Que Literato aventureiro é esse, que parece ter vindo da Lourinham? [sic]'. - Ignora ele acaso as dificuldades que encontra qualquer instituição portuguesa?”. Ao fim, o Bibliófilo assegurava aos redatores e leitores d'O Investigador que a "nova Dulcineia encantada não espera[va] pelos esforços de Quixote algum científico, para sair a público", sendo-lhe realizados os preparos. ${ }^{268}$ Não sabemos se a Biblioteca veio a público, mas pelo silêncio do periódico a partir de 1817 (que não faz mais nenhuma referência sobre o empreendimento), tudo indica que o projeto não tenha saído do papel.

266 IP. Vol. XIV, p. 246-248.

267 Ibid., p. 177 (Grifos do Original).

268 Ibid., p. 267-268 (Grifos do Original). 
A política cultural do governo joanino em relação à sua "coleção de bibliotecas" distribuídas nos dois lados do Atlântico expressava a concepção real de que estes locus de saber compunham uma das principais faces de um espelho, cuja imagem era a de um Império vigoroso e politicamente forte e saudável. Tamanha pretensão, no entanto, se desvaneceu ao longo do tempo. Desde o início da tormenta revolucionária no Velho Mundo, em 1789, que a Coroa Portuguesa lutava pela estabilidade do Império. No Reino, tal projeto foi inviável. Com a invasão napoleônica iminente, a travessia oceânica tornou-se uma realidade, que durou treze anos. Do Brasil, a tentativa de implantar um novo e poderoso Império também não se concretizou: com a morte de d. Rodrigo de Souza Coutinho (1812), o fim da era napoleônica (1815) e o ápice da crise do sistema absolutista português, a partir de 1817, era preciso repensar a estrutura do frágil Império que se tinha sob as mãos. Dirigí-lo de qual sede, Rio de Janeiro ou Lisboa?

A resposta chegou antes do previsto por D. João VI. Pouco mais de três anos depois de ter sido aclamado rei na América (1818), a Revolução do Porto (1820) exigia providências urgentes. Era a monarquia constitucional que se afigurava no horizonte. A dívida com os súditos portugueses, enfim, teria de ser paga. Por não tolerarem mais tamanha humilhação política, os revoltosos do Porto chamavam às Cortes. Na efervescente ebulição política dos anos 1820-1822, a emergência do novo espaço público liberal luso-brasileiro mostrava toda sua face. Este espaço, se se transformava em uma velocidade voraz, tinha como protagonista a própria sociedade. $\mathrm{O}$ conceito de cidadania agora fazia parte do vocabulário comum. ${ }^{269}$ Eram os cidadãos que lutavam por um

269 "Resultante da linguagem política das Luzes, cidadão, no entanto, segundo Telmo dos Santos Verdelho, não entrou na maneira de falar cotidiana do povo 
novo pacto político nos dois lados do oceano. Eram os cidadãos que à frente do Real Teatro de S. João no Rio de Janeiro exigiam que D. João aceitasse a constituição, em 26 de fevereiro de 1821. O Império Português, finalmente, tinha novos atores políticos e o Antigo Regime era obrigado a negociar com uma nova ordem em praça pública. "A prática liberal considerava a igualdade perante a lei como condição inerente ao cidadão, dando uma nova conotação política ao exercício da cidadania”, contextualiza Lúcia Pereira das Neves. ${ }^{270}$

Em 1821, uma parte dos manuscritos reais atravessava o oceano juntamente com D. João e seu séquito rumo ao Velho Mundo. Estavam quase a salvos, não fosse ter deixado no Rio de Janeiro o mais precioso de seus bens: a Real Biblioteca, que valia quatro vezes mais do que toda a prataria real. ${ }^{271}$ Não bastasse isso, ainda em 1821, os funcionários da livraria régia imprimiam seu Estatuto, que simbolizava, nas palavras de Lilia Schwarcz, "uma verdadeira carta de alforria do estabelecimento, que decididamente se assentava em terras tropicais". 272

Ao longo desses anos a opinião tornava-se senhora da razão e tomava as ruas do Império. Em Coimbra ou em Belém do

português. Ao contrário do uso à época da Revolução Francesa, quando foi empregado como um título que substituía os termos senhor ou dom, a palavra, um nome comum, indiferenciado, referia-se a qualquer membro da sociedade. [...] No Brasil, o termo [cidadão] significava a designação oficial do indivíduo politicamente integrado à Nação: 'usando de nossos direitos naturais, começamos a ser homens, [...]pelo exercício de nossos direitos civis principiamos a ser cidadãos". Ainda de acordo com Neves, "Insistia-se, assim, nos vários níveis de cidadania política, ficando claro que o cidadão destaca-se por seu mérito e suas posses. Todos podiam ser chamados de cidadãos, com exceção dos escravos, no Brasil”. NEVES, Lúcia Maria Bastos P. Corcundas... Op. Cit., p. 180-181.

270 Ibid., p. 181.

271 SCHWARCZ, Lilia. A longa viagem... Op. Cit., p. 400.

272 Ibid., p. 403. 
Pará, em Salvador ou no Porto, em Lisboa, ou no Rio de Janeiro. A crítica ao status quo adentrava o século XIX luso-brasileiro. Mesmo com toda a política governamental de coibição das ideias sediciosas, os sujeitos históricos d'Oitocentos liam a realidade à sua volta de uma maneira muito diferente de antes da Revolução Francesa. A imprensa? Os manuscritos? Os livros? As peças de teatro? A biblioteca? Sim, todos estes espaços de saber, ou de produção de novas leituras, olhares e conhecimentos, foram fundamentais para a formação de outra identidade coletiva. Esta, no início da década de 1820, começava a trilhar o caminho da soberania política. 